University of Tennessee Health Science Center UTHSC Digital Commons

$12-1979$

\title{
Characteristics of the Recovery of the Coenzyme A-Synthesizing Protein Complex from Saccharomyces Cerevisiae
}

Stanley Joseph Tarnowski Jr.

Follow this and additional works at: https://dc.uthsc.edu/dissertations

Part of the Chemical and Pharmacologic Phenomena Commons, Enzymes and Coenzymes Commons, Investigative Techniques Commons, and the Medical Biochemistry Commons 


\title{
Characteristics of the Recovery of the Coenzyme A-Synthesizing Protein Complex from Saccharomyces Cerevisiae
}

\begin{abstract}
A multienzyme complex contained in Bakers' yeast (Saccharomyces cerevisiae) which synthesizes CoA has been named the coenzyme A-synthesizing protein complex (CoA-SPC). The CoA-SPC has been shown to be insoluble in the crude Bakers' yeast cell lysate formed by exposing the yeast cell to ether and dry ice. Only after solubilization has this multienzyme complex been shown to catalyze the formation of bound dephospho-CoA utilizing the substrates adenosine triphosphate, D-pantothenic acid and Lcysteine. A low molecular weight component or components of the soluble fraction of the yeast cell and chloride ion appears to be responsible for the solubilization of CoA-SPC. This endogenous component of the yeast cell is referred to as t-Factor.

Purification of t-Factor has been accomplished by techniques which have included dialysis, ultrafiltration and paper, permeation, adsorption and ion-exchange chromatography. Although the t-Factor has not been identified, several properties have been demonstrated: (1) the molecular weight is between 400 to 1,000; (2) it is stable to heat at $80^{\circ} \mathrm{C}$ for 24 hours; (3) it is resistant to hydrolysis by trypsin and protease; (4) it is inactivated by ashing; and (5) has no ultraviolet absorption at 260 mu and 280 my.
\end{abstract}

Replacement of t-Factor by commercially available compounds or solubilizing agents has failed to reveal its identity. A "one-step" purification of CoA-SPC may be obtained by combining partially purified t-Factor with insoluble yeast cell residue.

An alternate procedure was developed for the preparation of CoA-SPC. This procedure involves the slow drying and rehydration of the yeast cells, but the need for t-Factor still remains. Sonic oscillation and passage through a french pressure cell, two of the more classical cell breakage techniques, fail to produce active CoA-SPC preparations.

Document Type

Dissertation

Degree Name

Doctor of Philosophy (PhD)

Program

Biochemistry

Research Advisor

Edsel Bucovaz

\section{Subject Categories}

Analytical, Diagnostic and Therapeutic Techniques and Equipment | Chemical and Pharmacologic Phenomena | Chemicals and Drugs | Enzymes and Coenzymes | Investigative Techniques | Medical Biochemistry | Medical Sciences | Medicine and Health Sciences 
CHARACTERISTICS OF THE RECOVERY OF THE COENZYME A-SYNTHESIZING PROTEIN COMPLEX FROM

\title{
SACCHAROMYCES CEREVISIAE
}

\author{
A Dissertation \\ Presented to the \\ Graduate Medical Sciences Council \\ of
}

The University of Tennessee

In Partial Fulfillment

of the Requirements for the Degree Doctor of Philosophy

by

Stanley Joseph Tarnowski, Jr. December, 1979 


\section{ACKNOWLEDGEMENTS}

I would like to thank my major professor, Dr. E. T. Bucovaz, for allowing me to carry out this project in his laboratory. Through his experience and constant observations I was able to develop a very fertile research program. I am grateful to Dr. Bucovaz for being more than a major professor, but a friend. He has taught me what science is really all about, that was to make the most out of every experiment. I hope that some of his persistance and ingenuity has rubbed off on me, as I know it will be invaluable throughout my career.

I would like to extend my appreciation to Dave Whybrew for teaching me the essential assays needed to carry out this study. I would especially like to thank him for being my friend and golfing partner for the past three years.

I would like to extend my appreciation to the members of my committee: Dr. William E. Jefferson, Dr. George E. Bass, Dr. Robert M. Macleod, and Dr. Robert E. Shade for their patience in reading this manuscript in sections and for their criticism.

I do not know the words that describe my appreciation to Ms. Camille Orgertrice, other than she was great! Very rarely do you find a person that will sacrifice every minute 
ii i

of spare time, from family and friends, like Camille, to type a thesis from start to finish. Her assistance was invaluable.

Lastly, I would like to thank my wife, Deborah Kay, for standing beside me during this endeavor. She has tolerated conditions many women would not and I love her for maintaining harmony during some rugged times. 
ABSTRACT

A multienzyme complex contained in Bakers' yeast (Saccharomyces cerevisiae) which synthesizes COA has been named the coenzyme A-synthesizing protein complex (COA-SPC). The COA-SPC has been shown to be insoluble in the crude Bakers' yeast cell lysate formed by exposing the yeast cell to ether and dry ice. Only after solubilization has this multienzyme complex been shown to catalyze the formation of bound dephospho-COA utilizing the substrates adenosine triphosphate, D-pantothenic acid and L-cysteine. A low molecular weight component or components of the soluble fraction of the yeast cell and chloride ion appears to be responsible for the solubilization of COA-SPC. This endogenous component of the yeast cell is referred to as t-Factor.

Purification of t-Factor has been accomplished by techniques which have included dialysis, ultrafiltration and paper, permeation, adsorption and ion-exchange chromatography. Although the t-Factor has not been identified, several properties have been demonstrated: (1) the molecular weight is between 400 to 1,$000 ;$ (2) it is stable to heat at $80^{\circ} \mathrm{C}$ for 24 hours; (3) it is resistant to hydrolysis by trypsin and protease; (4) it is inactivated by ashing; and (5) has no ultraviolet absorption at $260 \mathrm{m \mu}$ and $280 \mathrm{m \mu}$. 
v

Replacement of t-Factor by commercially available compounds or solubilizing agents has failed to reveal its identity. A "one-step" purification of COA-SPC may be obtained by combining partially purified t-Factor with insoluble yeast cell residue.

An alternate procedure was developed for the preparation of COA-SPC. This procedure involves the slow drying and rehydration of the yeast cells, but the need for $t$-Factor still remains. Sonic oscillation and passage through a french pressure cell, two of the more classical cell breakage techniques, fail to produce active COA-SPC preparations. 
TABLE OF CONTENTS

CHAPTER

PAGE

I INTRODUCTION AND LITERATURE REVIEW • • . . . 1

structure of Coenzyme A (COA) . . . . . 2

Pantothenate Moiety . . . . . . . . 2

Nucleoside Moiety . . . . . . . . 4

Pantetheine Moiety . . . . . . . . 5

Phosphate Linkages. . . . . . . . 8

Biosynhesis of COA. . . . . . . . 15

Bacteria . . . . . . . . . . . 15

Vertebrates . . . . . . . . . . 22

Yeasts . . . . . . . . . . . 31

Possible Regulation in the Biosynthesis of Coenzyme A . . . . . . . . . . 35

Degradation of Coenzyme $A$ in the Cell . . 37

Functional Group of Coenzyme A. . . . . 40

I I STATEMENT OF THE PROBLEM. . . . . . . . . 50

II MATERIALS AND METHODS . . . . . . . . . 53

Involvement of $t-F a c t o r$ in the Prepara-

tion of the Coenzyme A-synthesizing

Protein Complex of Bakers' Yeast. . . .

Preparation of pellets containing

COA-SPC . . . . . . . . . . . . 
Preparation of $t$-Factor ......

Assay for COA-SPC Activity. . . . .

Components of the reaction mixture.. .

Incubation of the reaction mixture. .

Precipitation procedure . . . . . .

Collection of protein precipitates. .

Determination of Radioactivity. . . .

Calculations. . . . . . . . . .

COA-SPC activity. . . . . . . .

Specific activity . . . . . . .

Determination of Protein. . . . . .

Preparation of protein standards...

Protein standard curve........

Calculation of protein concentration. .

Preparation of reagents for protein

determinations. . . . . . . .

Assay for t-Factor Activity by the

Solubilization of COA-SPC ......

Alternate Method for the Preparation

of $t$-Factor . . . . . . . . .

Filtration of the t-Factor through Dialysis Tubing. . . . . . . . . .

Cone Filtration of t-Factor . . . . .

Membrane Ultrafiltration of t-Factor. .

Heat stability of t-Factor. . . . . 
Proteolytic Treatment of t-Factor . . .

Incubation of the samples . . . . .

Recovery of samples . . . . . . .

Assessment of $t$-Factor. . . . . . .

Proteolytic Activity Assessment . . .

Qualitative . . . . . . . . . .

Plate incubation. . . . . . . . .

Detection . . . . . . . . . .

Controls for diffusion zone

visualization . . . . . . . . .

Samples for qualitative detection of

proteolytic activity. . . . . . .

The Effect of the Concentration of $t$-Factor on the Solubilization of COA-SPC. . . .

Ashing of t-Factor........... .

Treatment of the ash. . . . . . .

Paper Chromatography. . . . . . . .

Development of preparative

chromatograms . . . . . . . . .

Chromatographic solvents. . . . .

Extraction of paper chromatograms . .

Qualitative paper chromatography. . .

Detection of separated compounds. . .

Permeation Chromatography of t-Factor

on Sephadex G-10. . . . . . . . . . 
Preparation of the column .. . . . .

Elution method. ............

Assay method. . . . . . . . . 78

Molecular Weight Estimation of t-Factor .

Treatment of t-Factor with Charcoal . .

Assay . . . . . . . . . . . .

Treatment of t-Factor with Ion-Exchange Resin . . . . . . . . . . . .

Assay . . . . . . . . . . . . .

The Effect of Various salts on the

Recovery of COA-SPC . . . . . . . .

Assay . . . . . . . . . . . .

Estimation of Endogenous Chloride . . .

Reagents. . . . . . . . . . . .

standardization of mercuric nitrate .

Sample titrations . . . . . . . 84

Assessment of t-Factor Purity . . . . .

Testing known Compounds for t-Factor

Activity. . . . . . . . . . . . .

Alternate Procedure for the Preparation of CoA-SPC from Bakers' Yeast. . . . . .

Estimation of yeast cell volume . . .

Drying the yeast cells. . . . . .

Rehydration of dried yeast cell 
CHAPTER

PAGE

Solubilization of COA-SPC . . . . . 86

Assays of yeast cell extract. . . . . 87

IV RESULTS AND DISCUSSION. . . . . . . . . 88

Recovery of COA-SPC .......... 88

Discovery of the Yeast Component

t-Factor. . . . . . . . . . .

Alternate Methods for the Isolation

of t-Factor...............

Effect of Heat on t-Factor. . . . . 102

Concentration of t-Factor on the

Solubilization of COA-SPC . . . . . .

Action of Proteolytic Enzymes on

t-Factor. . . . . . . . . . . .

Preparative Paper Chromatography. . . .

Elution Pattern of t-Factor on

Sephadex G-10 . . . . . . . . .

Molecular Weight Estimation of t-Factor .

Requirement for $\mathrm{KCl}$ or Chloride Ion . .

Compounds Tested for t-Factor Activity. .

Testing t-Factor and Solubilized COA-SPC

for Proteolytic Activity. . . . . . .

Treatment of $t$-Factor with Charcoal . .

Treatment of $t$-Factor with Ion-Exchange Resin . . . . . . . . . . . . 
$\mathbf{x i}$

CHAPTER

PAGE

Purification of t-Factor. . . . . .

Purification of COA-SPC Utilizing

t-Factor. . . . . . . . . . . .

Alternate Method for the Production of

COA-SPC . . . . . . . . . . . .

V SUMMARY . . . . . . . . . . . . . . . .

BIBLIOGRAPHY . . . . . . . . . . . . . . .

145

VITA . . . . . . . . . . . . . . . . .

156 
Reactions Involving CoA and Acyl Carrier Protein . . . . . . . . . . . .

II COA-SPC Activity of the Yeast Cell Lysate. .

II Yeast Cell Component Essential for the Solubilization of COA-SPC . . . . . . .

IV Solubilization of COA-SPC with Various

Subfractions of the crude supernatant . . . 100

$v$ The Effect of Heat on t-Factor Activity . .

VI Effect of the Concentration of $t$-Factor on

the Solubilization of COA-SPC . . . . . . 106

VII Effect of Proteolytic Enzymes on t-Factor .

VIII Preparative Paper Chromatography of t-Factor. . . . . . . . . . . . .

IX Effect of Various salts on the solubilization of COA-SPC. . . . . . . . . . . . .

$\mathrm{x}$ Compounds Tested for t-Factor Activity. . .

$X I$ Estimate of the Purification of $t$-Factor

Based Upon Indirect Assay . . . . . . .

XII Purification of the COA-Synthesizing Protein

Complex (COA-SPC) by Purified t-Factor. . . 
XIII Effect of Drying Time and Temperature on Extraction of COA-SPC from Fresh Bakers' Yeast. .. . . . . . . . . . . . .

XIV Effect of Grinding on the Ability to Extract COA-SPC from Dried Yeast Solids .......

XV Effect of Particle Size of Dried Bakers'

Yeast on the Extraction of COA-SPC. . . . .

XVI Effect of the Concentration of Dried Bakers' Yeast Solids in Suspension on the Extraction of COA-SPC Activity . . . . . . . . .

XVII Effect of the Temperature of the water of Rehydration on the Extraction of COA-SPC from Dried Bakers' Yeast Solids ........

XVIII Effect of Temperature for Mixing the Rehydrated Dried Bakers' Yeast on the Extraction of COA-SPC Activity .............

XIX Effect of the Initial Removal of $t$-Factor of Fresh Bakers' Yeast on the Extraction of COASPC from the Remaining Dried Solid Residue. . 
1 Structure of COA . . . . . . . . . .

2 Biosynthetic Pathway of CoA from Pantothenic Acid . . . . . . . . . .

3 Alternate Pathway of Biosynthesis of COA. .

4 Assembly of Dephospho-COA by the Coenzyme A-Synthesizing Protein Complex . . . . . .

5 Possible Regulation in Biosynthesis of CoA in the Rat Liver Model . . . . . . .

6 Possible Pathway for the Degradation of COA . . . . . . . . . . . . . . .

7 Diagrammatic summary of the procedures for the Preparation of COA-SPC and Involvement of a Cellular Component for Its Recovery . .

8 Diagrammatic Summary of the Procedures for the Isolation of t-Factor. . . . . . .

9 The Location of t-Factor After Paper Chromatography . . . . . . . . . .

10 The Sephadex G-10 Elution Pattern of the Amicon UM-05 Filtrate Fraction Containing t-Factor . . . . . . . . . 
FIGURE

PAGE

11 The Sephadex G-10 Calibration Curve for the Estimation of the Molecular Weight of $t$-Factor. . . . . . . . . . . . 115

12 Testing Proteolytic Activity in Various t-Factor Fractions and COA-SPC Solubilized by Crude and Purified t-Factor . . . . . 
CHAPTER I

\section{INTRODUCTION AND LITERATURE REVIEW}

A seemingly unimportant side reaction of the detoxification of aromatic amines was found to require an unidentified, heat-stable, dialyzable component of the soluble extract of pigeon liver (1). The enzymes, catalyzing the conjugation of acetate to sulfanilamide, were reactivated in the presence of this unidentified component. The same liver extract component was found to be identical to the coenzyme required for the acetylation of choline in brain extracts (2). In 1947, the liver extract component was named coenzyme A (COA) to represent its significance in acetylation reactions (3). Coenzyme A was shown not to be one of the B vitamins, but because COA was inactivated by alkaline phosphatase and enzyme(s) from liver extract to yield a component necessary for the pantothenate-requiring bacteria Lactobacillus arabinosus (ㄴ. arabinosus) to thrive, CoA was considered to be a pantothenic acid derivative (3). The name "Pantothenic" acid was derived from the Greek word meaning "everywhere". As R. J. Williams has demonstrated (4), pantothenic acid can be extracted from many plant, animal and microorganism sources for the use as a growth factor. Novelli et al. (5) found 
that most, if not all of the cellular pantothenic acid contained in animal tissues and bacterial cells, was bound in the form of CoA. A similar study by Brown in 1959 confirmed Novelli's view, but pointed out that significant amounts of bound pantothenic acid were contained in the form of CoA intermediates (6). These findings made a rather outstanding contribution to the field of biochemistry by bestowing a metabolic function to pantothenic acid. The search then began by a combination of chemical, enzymic and microbiological methods to establish the complete structure of CoA. During the structural identification, some of the biosynthetic mechanisms were suggested. The following will review the structural analysis and biosynthetic mechanisms of COA.

Structure of Coenzyme $\underline{A}$ (COA)

The fully established structure for $\operatorname{CoA}$ is shown in Figure 1. The structure is presented here showing the different structural components so that easy reference can be made during the ensuing discussion.

\section{Pantothenate Moiety}

Coenzyme A concentrates treated with clarase (a phosphorlytic enzyme), papain (a saccharolytic enzyme), and prostate phosphatase failed to liberate pantothenic acid initially, but after prolonged treatment, a small amount could be detected. Acid hydrolysis, however, did yield B-alanine in an amount to indicate that $\mathrm{COA}$ was 10 percent pantothenic 


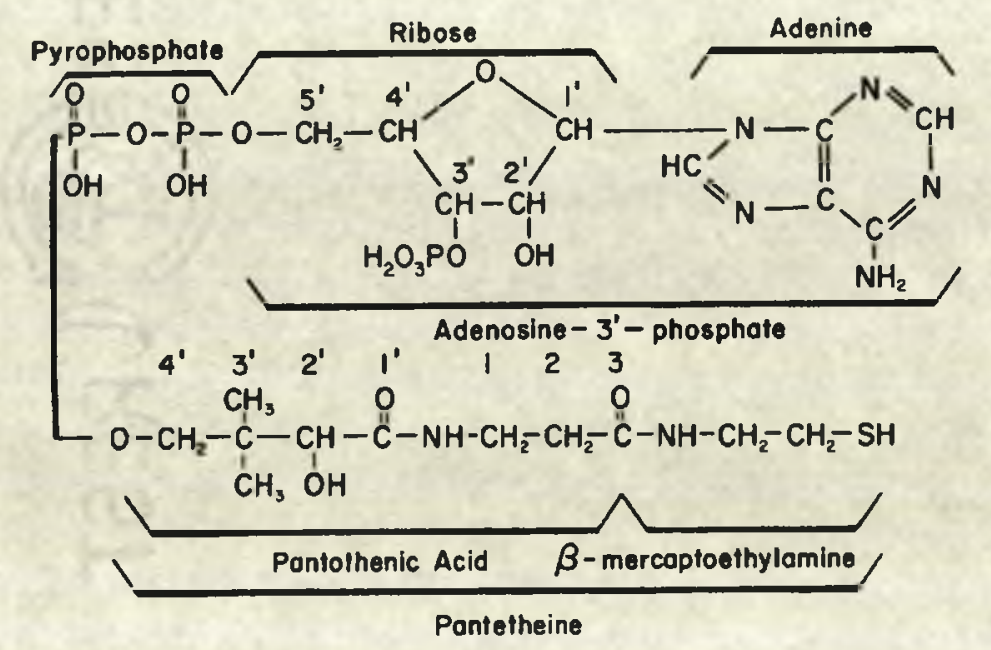

Figure 1. Structure of COA. 
acid (3). Coenzyme A treated with intestinal phosphatase, a mono and diphosphoesterase, inactivated $\mathrm{COA}$ so that it was unable to function during the acetylation of sulfanilamide, and the product from the treatment had little ability to stimulate the growth of $\underline{L}$. arabinosus. All of the organic phosphate accountable to $C O A$ was liberated by the treatment (5). Acetone-dried pigeon liver extract contains an enzyme(s) that inactivates COA, but does not remove organic phosphate. Additionally, the degradation product of this treatment was ineffective for the growth of $\underline{L}$. arabinosus. It was speculated then, that the liver extract was hydrolyzing a linkage somewhere in the molecule other than at phosphate linkages (5). The combination of enzymes in liver extract and intestinal phosphatase, were used to successfully inactivate $\mathrm{COA}$ and liberate 85 percent to 90 percent of the pantothenic acid as shown by the growth of $\underline{L}$. arabinosus. The structure for pantothenic acid has been defined (7) and is shown in the COA model in Figure 1.

\section{Nucleoside Moiety}

Impure preparations of COA showed strong ultraviolet light absorption at $260 \mathrm{~m} \mu$. This observation suggested COA may contain an adenine derivative. Formation of the picric acid derivative of the acid hydrolysate of CoA had a melting point $1^{\circ} \mathrm{C}$ greater than the picrate derivative formed from yeast adenylic acid (adenosine monophosphate; AMP) (8). The 
ultraviolet absorption of this impure COA preparation suggested the ratio of adenine to pantothenic acid was $2: 1$. However, preparations of COA extracted from the fermentation broth of streptomyces fradiae ( $\underline{s}$. fradiae) and purified by repeated adsorption and elution from charcoal $(9,10)$, showed the adenine/pantothenic acid ratio was one. The more pure preparations of $C O A$ were found to contain little reducing sugar (8) until upon acid hydrolysis pentose was detected by the orcinol method. The ribose was assumed to be bound to adenine probably as adenosine. Adenosine was confirmed in COA preparations by treatment of the preparation with alkaline phosphatase, to liberate the nucleoside, followed by treatment with a specific adenosine deaminase $(10,11)$ to produce inosine plus $\mathrm{NH}_{3}$. This deaminase reaction was monitored by the decrease in absorptivity at $265 \mathrm{~m} \mu$.

\section{Pantetheine Moiety}

During the early purifications of $\operatorname{COA}(8,9)$, it was recognized that alkaline and acid hydrolysates produced an odor reminiscent of sulfur compounds. Sulfur content also increased parallel with COA activity (9). Whenever the COA preparation was tested for the presence of sulfhydryl by the nitroprusside reagent, the result was negative (8). However, when the COA preparation was treated with sodium cyanide, a reducing agent, the preparation gave a strong positive nitroprusside test. The suggestion was that CoA contained sulfur 
in disulfide linkage in the form of cystine (8). Acid hydrolysates of $\mathrm{COA}$ when chromatographed on paper showed a compound closely resembling cysteine that gave a positive nitroprusside reaction and a positive ninhydrin reaction, indicating that an amino group was present (9). Intestinal phosphatase treated $C O A$ when chromatographed on paper showed three migrating spots that contained both pantothenic acid and sulfur. The fastest moving component when extracted contained no adenosine, but pantothenic acid was liberated when the component was treated with avian liver extract; therefore, this suggested a split of the linkage between pantothenic acid and the sulfur compound (9). At this stage of development, it was estimated that COA contained two moles of sulfur (9), but the addition of a reduction step by $z$ inc and hydrogen chloride during the purification procedure of CoA abolished disulfide crosslink formation and showed that $C O A$ contained only one mole of sulfur relative to pantothenic acid (10).

A major step forward in understanding the structure of COA was derived from an apparent unrelated topic. Yeast extracts were found to contain a factor necessary for the growth of Lactobacillus bulgaricus (․ bulgaricus) (12). The factor was found to be neither strongly acidic or basic, but it could be destroyed by alkali or acid. The factor named Lactobacillus bulgaricus factor (LBF) was found to be widely distributed, with yeast being the richest source, and could 
be used as a growth factor by other microorganisms, in particular Lactobacillus helveticus (‥ helveticus).

A possible link between $L B F$ and $C O A$ was suspected when LBF was found to be closely related or identical to the CoA degradation product formed with intestinal phosphatase (13). Additional evidence of the connection between COA and LBF was shown by the fact that the COA degradation product could stimulate growth of $\underline{L}$. helveticus, and both the CoA degradation product and LBF were destroyed by avian liver extract to yield pantothenic acid. LBF could be substituted for pantothenic acid with 25 percent of the activity to grow $\underline{L}$. arabinosus and only large amounts of pantothenic acid could grow L. helveticus (13).

Acid hydrolysis of LBF yielded products which gave positive ninhydrin and nitroprusside reactions. There appeared to be no free amino or carboxyl groups $(14,15)$ in the unhydrolyzed LBF. It was suggested that a amide linkage existed between pantothenic acid and a mercaptoamine (or its disulfide) since $\beta$-mercaptoethylamine ran closely to the ninhydrin-nitroprusside positive acid hydrolyzed fragment of LBF $(14,15)$. As previously mentioned, avian liver extract freed pantothenic acid from LBF, therefore a chemical synthesis was carried out using methyl pantothenate, $B$-mercaptoethylamine, and acetamide to produce a compound with a $R_{f}$ value close to LBF. Accordingly, LBF was then speculated to exist as N(pantothenyl)- $\beta$-aminoethanol or the disulfide. The names 
pantetheine for the thiol, and pantethine for the disulfide were suggested for LBF (14).

The commonalities between LBF and COA continued to be observed as it was shown that synthetic pantetheine could be converted to $\mathrm{COA}$ by incubation with adenosine triphosphate (ATP) and pigeon liver extract (16). The acid hydrolysate of COA was subjected to steam distillation and found to produce a ninhydrin-nitroprusside compound identical with B-mercaptoethylamine by paper chromatography $(17,18)$. The entire amount of sulfur contained in COA preparations could be accounted by the $\beta$-mercaptoethylamine residue (18). The chemical and biological considerations have made it clear that pantetheine was contained within the CoA molecule. The pantetheine moiety can be seen in Figure 1, page 3.

\section{Phosphate Linkages}

Coenzyme A contains three phosphate groups $(9,10,19)$. Adenosine bears three hydroxyl groups and one amino group, and pantetheine has two hydroxyl groups and one sulfhydryl; therefore, the possible combinations of these groups as esters with phosphate or pyrophosphate are numerous. As with the other components of COA, a combination of chemical and enzymic methods have proven successful for determining the type and position of the phosphate linkages.

The combined action of alkaline phosphatase and the unidentified avian liver extract have been used to liberate 
pantothenic acid from intact $\operatorname{COA}(3,5)$. The liver enzyme(s) was known to hydrolyze the amide linkage between pantothenic acid and $\beta$-mercaptoethylamine (cysteamine) (14). The phosphatase, being rather nonspecific, showed only that in some way phosphate must be linked to the pantotheinyl residue.

A COA degradation product produced by the action of a liver enzyme alone was found to stimulate the growth of the bacterium Acetobacter suboxydans (프 suboxydans), but not to be stimulatory to the growth of $\underline{L}$. arabinosus (20). The degradation product was believed to be identical to a pantothenic acid derivative from heart muscle, also known to stimulate the growth of $\underline{A}$. suboxydans (21). Since both substances' growth stimulatory ability were lost through the action of intestinal phosphatase (20), it was felt "Acetobacter stimulatory factor" (ASF) was a simple phosphoric ester of pantothenic acid. The possible phosphate ester derivatives of pantothenic acid were synthesized $(17,22,23)$. Since 2'-phosphopantothenic acid, $4^{\prime}$-phosphopantothenic acid, 2',4'-diphosphopantothenic acid, and cyclic-2',4'phosphopantothenic acid could not stimulate the growth of $\underline{A}$. suboxydans, it was found that ASF was not a simple mono or diphosphate of pantothenic acid. The synthetic derivatives did, however, confirm more of the structural features of CoA. When contained in $C O A$, the pantothenic acid residue has greater stability toward acid and alkali than the free vitamin $(17,25)$. The amide linkage in the synthetic derivatives 
was also found to be very stable. By comparing the rate of alkaline hydrolysis of the amide linkage in COA to rates of hydrolysis of the amide bonds in $4^{\prime}$-phosphopantothenic acid and 2'-phosphopantothenic acid, the rate closely corresponded to $4^{\prime}$-phosphopantothenic acid (4). It was suggested 4'phosphopantothenic acid was contained in COA.

4 '-phosphopantothenic acid was confirmed as a structural component when acid and alkaline hydrolysates of COA showed the presence of a perchloric-molybdate (for organic phosphate) positive spot with a $R_{f}$ value identical to synthetic 4'-phosphopantothenic acid (17). Scanning the paper with ultraviolet light showed no evidence that a purine ring was associated with 4'-phosphopantothenic acid of the COA hydrolysate. This was confirmed by the isolation and full chemical characterization of the alkaline hydrolyzed product of COA (25).

Acid hydrolysis of liver enzyme treated COA revealed the presence of $\beta$-mercaptoethylamine (cysteamine) (17). Combined with the data that the phosphate derivatives were inactivate for stimulating the growth of $\underline{A}$. suboxydans, it was speculated that ASF might be $4^{\prime}$-phosphopantetheine (17). Since it was difficult to purify $4^{\prime}$-phosphopantetheine from COA hydrolysates, it was synthesized (26). Chromatography on paper revealed that synthetic $4^{\prime}$-phosphopantetheine and the product of CoA hydrolysis had simiar $R_{f}$ values It was found that 4'phosphopantetheine isolated after paper chromatography of COA 
hydrolysates and synthetic $4^{\prime}$-phosphopantetheine were convertible to $\mathrm{COA}$ in the presence of ATP and partially purified pigeon liver extract $(26,27)$. Only the $\underline{D}$-isomer of the synthetic $4^{\prime}$-phosphopantetheine was convertible to COA when a mixture of DL-4'-phosphopantetheine was used (27). It was confirmed that the liver degradation product of COA and ASF was $4^{\prime}$-phosphopantetheine (27).

A pyrophosphate linkage was suspected in the structure of COA when it was observed that COA was rapidly deactivated by potato extract containing a pyrophosphatase (28). This observation was initially challenged when repeated experiments failed to show a split and inactivation of $C O A$ which led King and strong (24) to present an incorrect structure for $C O A$. It has now been accepted that the misinterpretation was caused by a difference in the $\mathrm{pH}$ optimum used for the inactivation of $\operatorname{COA}(29)$. King and Strong used Kornberg's (30) potato nucleotide pyrophosphatase with a pH optimum near 7.5, whereas Novelli's (29) potato COA pyrophosphatase had a $\mathrm{pH}$ optimum near 5.0. Eventually, the issue was resolved when it was shown that snake venom pyrophosphatase would inactivate $\operatorname{COA}(31,32)$, that alkaline phosphatase inactivation could not be replaced by a phosphomonoesterase (30), and chemical evidence for the pyrophosphate structure was obtained $(25)$.

At this point, considerable advances had been made for determining the structure of $\mathrm{COA}$, but the nature of the 
pyrophosphate linkage between pantetheine and adenosine were yet to be determined. The remaining discussion will focus on how this portion of the COA structure was resolved.

The pyrophosphate linkage in $\mathrm{COA}$ is the bond most easily hydrolyzed by the action of acid or alkali (26). When COA is hydrolyzed by acid or alkali, a number of phosphoric esters are formed. One of the hydrolysis products was identified to be adenosine $5^{\prime}$-phosphate (5'-adenylic acid; $5^{\prime}$-AMP) when compared with a synthetic sample by paper chromatography (17) •

As with the establishment of the pyrophosphate linkage in $C O A$, potato pyrophosphatase (30) was used to generate a nucleotide degradation product identified to be adenosine 5'phosphate. The adenosine 5'-phosphate was identified by the use of Schmidt's deaminase $(11,19)$, an enzyme specific for distinguishing between adenosine $5^{\prime}$-phosphate and adenosine 3'-phosphate. In addition to adenosine 5'-phosphate, adenosine was found as a product of potato pyrophosphatase. This was later determined to be a by-product due to contaminating adenosine $5^{\prime}$-phosphatase in the pyrophosphatase preparation (29). Further purification of the potato extract resolved this ambiguity. The adenosine 5'-phosphate product was also confirmed by paper chromatography (29).

The chemistry of nucleosides and nucleotides has revealed a very important structural feature of $C O A$. It was found that CoA contained three moles of phosphate $(9,10,19)$. 
One mole could be liberated by prostate phosphomonoesterase $(19,29,32)$ and two moles could be liberated by intestinal phosphatase, an enzyme that contains diphosphoesterase activity $(19,29)$. Since the nature of the pyrophosphate linkage had been established and the pyrophosphatase hydrolysis products yielded adenosine $5^{\prime}$-phosphate, the position of the monophosphate needed to be established. When chromatographed on paper nucleosides and nucleotides, unsubstituted at the 2'- and 3'-positions can be demonstrated by a stable blue color when oxidized with periodate to dialdehydes and sprayed with Schiff's reagent (33). Intact $\mathrm{COA}$, when treated as described, failed to produce the stable blue color and therefore, it was suggested COA was substituted with monphosphate at either the $2^{\prime}$ - or $3^{\prime}$-position of adenosine (17). Further chemical methods were unavailable to resolve the position of the monophosphate, so enzymic methods were used.

Alkaline hydrolysis of ribonucleic acid produced two isomeric monophosphates of adenosine respectively, referred to as the $2^{\prime}-$ and $3^{\prime}$-phosphates of adenosine (34). A phosphatase has been isolated from barley which was specific for the hydrolysis of the $3^{\prime}$-nucleotides, but had no action on either the $2^{\prime}$ - or $5^{\prime}$-nucleotides (31), as opposed to prostate phosphatase which attacks all three phosphate substituted nucleotides. The barley enzyme hydrolyzes one phosphate group in $C O A$, but the $C O A$ was not inactivated in the sulfanilamide assay $(31,32)$. It was found that the 
dephosphorylated $\mathrm{COA}$ was reactivated to $\mathrm{COA}$ in the presence of ATP and pigeon liver extract. Using the arsenolysis method for the production of acetylphosphate by transacetylase, COA was shown to be inactivated by the barley enzyme. It was then assumed that COA was substituted at the 3'-position of adenosine.

More evidence showing that the phosphate was linked to the $3^{\prime}$-position of the adenosine portion of $C O A$ will be summarized. By comparing the action of barley $3^{\prime}$-nucleotidase on $C O A$ and nicotinamide adenine dinucleotide phosphate (NADP), no phosphate was liberated from NADP. Nicotinamide adenine dinucleotide phosphate is substituted at the 2'position of adenosine. Purified snake venom, when incubated with $C O A$ and NADP, produced the products $3^{\prime}, 5^{\prime}$-adenylic acid and $2^{\prime}, 5^{\prime}$-adenylic acid $(31,32)$, respectively. These products were separated by paper chromatography and isolated. The diphospho-adenosine fragments were incubated with barley $3^{\prime}$-nucleotidase and a specific 5'-adenylic acid deaminase (Schmidt's deaminase), while the decrease in absorptivity at $265 \mathrm{~m} \mu$ was monitored. The 5'-adenylic acid from CoA was established by paper chromatography against an authentic standard. The diphosphate from COA produced adenosine by the action of barley 3'-nucleotidase followed by the specific 5'nucleotidase (32), whereas the diphosphate of NADP did not liberate adenosine. A deaminase, taka-diastase deaminase, which is specific for $3^{\prime}$-adenylic acid, was able to deaminate 
the diphosphate product of $\mathrm{COA}$ but was ineffective for deaminating the 2',5'-diphosphate from NADP. In the presence of acid, phosphate groups can migrate within the adenosine structure from the $2^{\prime}$-position to the $3^{\prime}$-position (34) to yield equilibrium mixtures. Therefore, in the presence of acid, NADP can be converted to the $3^{\prime}$-substituted form and the barley $3^{\prime}$-nucleotidase can then hydrolyze the phosphate group from 3'-NADP. The combined evidence therefore, showed COA contains adenosine 3',5'-diphosphate which can be seen in Figure 1, page 3. The final structure for $\operatorname{COA}$ emerged from the experimental evidence presented.

\section{Biosynthesis of $\mathrm{COA}$}

The structural identification of $\operatorname{COA}$ through the use of microbiological assay of hydrolysis products suggested possible assembly mechanisms for COA. The pathways for biosynthesis in bacteria, animals, and yeast were elucidated on the basis of the substrate specificity of the enzymes catalyzing the respective metabolic reactions. The bacteria and yeast systems will be discussed, but the most extensive work has been accomplished with the purified rat liver enzymes.

\section{Bacteria}

The discussion henceforth, will only consider the enzymatic reactions from pantothenic acid to $\mathrm{COA}$. It was found when using the pantothenic acid requiring organism L. arabinosus, that $C O A$ formation increased when pantothenic acid was 
present with casein hydrolysates (35). When individual amino acids were tested, cystine or cysteine were the only amino acids found to be effective. This amino acid requirement could not be substituted for by $\beta$-mercaptoethylamine, a known component of $\operatorname{CoA}(14,15,17,18)$. Additionally, $\mathrm{Mg}^{+2}$ and ATP were required for $C O A$ to be synthesized from pantothenic acid and cysteine. If, however, cysteine was excluded from the culture media, pantothenic acid was still taken up by the cells, and free pantothenic acid could be liberated by the action of intestinal phosphatase. The implication of this finding was that pantothenic acid was phosphorylated. This was confirmed by the isolation of a product from cells grown in the presence of pantothenic acid that corresponded closely to synthetic $4^{\prime}$-phosphopantothenic acid in terms of paper chromatography (36) and lability of the amide linkage to alkaline hydrolysis (37). Cell free extracts of $\underline{\text { L }}$ arabinosus were found to contain an enzyme for the phosphorylation of $\underline{D}$ pantothenic acid in the presence of ATP and $\mathrm{Mg}^{+2}$ (37). Likewise, extracts of proteus morganii ( $\underline{p}$. morganii) contained an enzyme, that when partially purified, could phosphorylate pantothenic acid, pantethine and pantetheine (38). Additionally, the rates of phosphorylation of one substrate was inhibited by the addition of one of the other substrates (39), suggesting that the kinase activities are the property of a single enzyme. This kinase appeared not to phosphorylate pantothenoyl L-cysteine, but a homogenous pantothenate 
kinase isolated from Brevibacterium ammoniagenes (ㅁ. ammoniagenes) was found to have that ability, in addition to its other phosphorylating activities $(40)$.

Although cysteine was required to produce $C O A$ when pantothenic acid was in the growth media of $\underline{L}$. arabinosus, panthethine could completely replace the two substrates, suggesting cysteine may participate in the formation of the $\beta-$ mercaptoethylamine portion of COA (35). Extracts of acetonedried cells of $\underline{p}$. morganii transformed pantothenic acid in the presence of ATP, $\mathrm{Mg}^{+2}$ and cysteine to a derivative inactive for the growth stimulation of pantothenic acid requiring Saccharomyces carlsbergensis (‥ carlsbergensis), L. arabinosus, and Lactobacillus casei (ㄴ. casei), but was very effective for the growth of $\underline{A}$. Suboxydans (41). The derivative has since been identified to be 4'-phosphopantetheine (27), and it was suggested that pantothenoyl-Lcysteine was phosphorylated before decarboxylation to 4'phosphopantetheine (41). These compounds appear to be most effective as growth factors and synthetic intermediates when present in the reduced (thiol) form $(39,41,42)$.

ward et al. (38) first suggested the pathway for COA biosynthesis shown in Figure 2. However, the extensive work

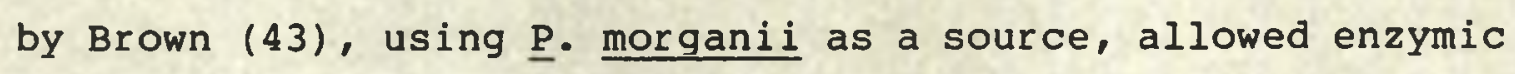
activities to be separated and established.

Brown (39), using ammonium sulfate fractionation and calcium phosphate gel, separated pantothenate kinase from 
$\mathrm{H}_{2} \mathrm{C}$ OH
I I
$\mathrm{HOCH}_{2} \mathrm{C}-\mathrm{CHCONHCH} \mathrm{CH}_{2} \mathrm{COOH}$
CH,

Pantothenic acld

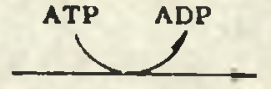

$\mathrm{O} \quad \mathrm{H}_{2} \mathrm{C}$
$\mathrm{OH}$
$\mathrm{HO}-\mathrm{OH}_{\mathrm{P}}-\mathrm{OCH}_{2} \mathrm{C}$
OH
OH

4'-Phosphopantothenic acid

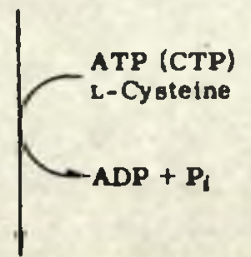

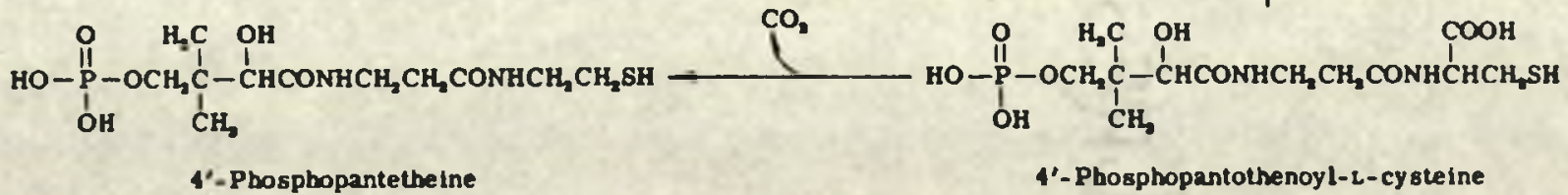
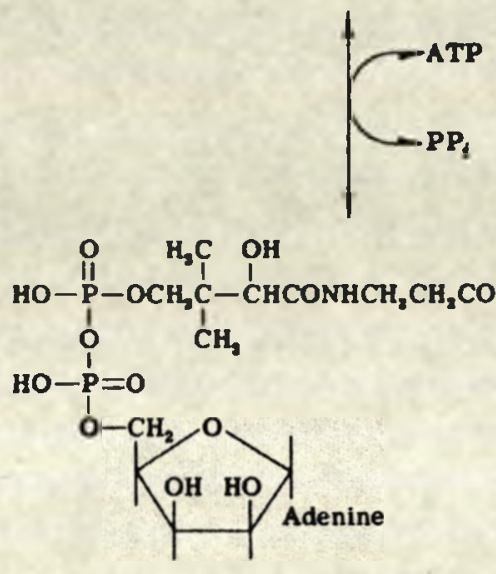

Dephospho-CoA

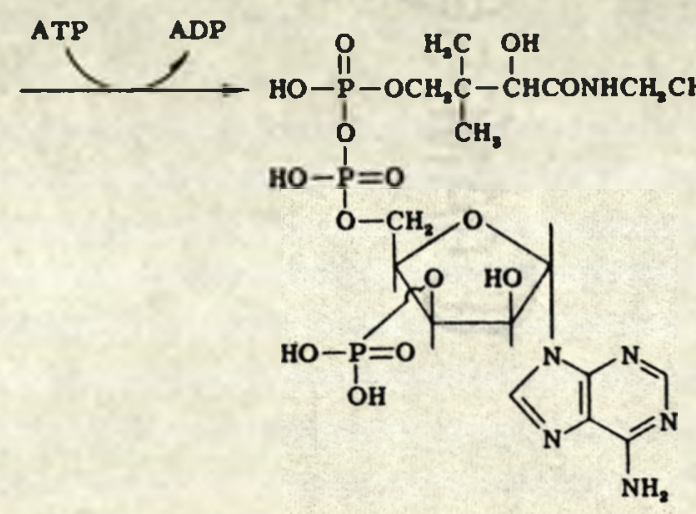

CoA

Figure 2. Biosynthetic pathway of COA from pantothenic acid. 
pantothenoyl-L-cysteine synthetase, the "coupling enzyme". The kinase phosphorylated pantothenic acid at the 4'-hydroxyl position in the presence of ATP and $\mathrm{Mg}^{+2}$ to yield $4^{\prime}$-phosphopantothenic acid. Although the kinase could phosphorylate other substrates $(38,40)$, Brown showed 4'-phosphopantothenic acid to be an obligate substrate for pantothenoyl-L-cysteine synthetase. Pantothenoyl-L-cysteine synthetase could condense cysteine with only $4^{\prime}$-phosphopantothenic acid, but not pantothenic acid (43) to produce $4^{\prime}$-phosphopantothenoyl-Lcysteine. The synthetase has a specific requirement for cytidine triphosphate (CTP) and $\mathrm{Mg}^{+2}$. The synthetase can condense $\beta$-mercaptoethylamine in the place of cysteine to form 4'-phosphopantetheine, thereby by-passing the decarboxylation step (43). Since an enzyme had not been shown to exist for the decarboxylation of cysteine to B-mercaptoethylamine, this reaction probably does not occur in vivo. Phosphopantothenoyl-L-cysteine decarboxylase was separated in P. morganii extracts by ammonium sulfate fractionation and found to decarboxylate 4 '-phosphopantothenoyl-L-cysteine to 4 '-phosphopantetheine. The dephosphorylated intermediate pantothenoyl-L-cysteine could not be decarboxylated, thereby providing further evidence that the synthetic route in Figure 2 exists. The final stage of COA biosynthesis was the pyrophosphate bond formation between $4^{\prime}$-phosphopantetheine and 5'-AMP from ATP by dephospho-COA pyrophosphorylase and the 
subsequent phosphorylation of dephospho-COA in the presence of ATP by dephospho-CoA kinase.

Brown's proposed pathway (43) has gained support recently by studies conducted on other bacteria $(44,45)$; for example, Sarcina, Corynebacterium, and Brevibacterium were of interest because they could accumulate large amounts of COA and thus provide a more economical source of commercial COA. Although individual enzymes were not isolated, dried cell preparations were used to demonstrate enzyme activities based on the product formed from a particular precursor of the CoA pathway (45).

An alternate pathway has been shown to operate in some bacteria which includes pantothenoyl-L-cysteine and pantetheine as intermediates. This alternate pathway shown in Figure 3 was partly supported by the accumulation of pantetheine but not $4^{\prime}$-phosphopantothenic acid when $\underline{L}$. helveticus was cultured on pantothenic acid (6). Secondly, pantothenoyl-L-cysteine has been shown to be ten times as effective as pantothenic acid for stimulating the growth of $\underline{A}$. suboxydans $(40,41,46,47)$, thus suggesting a limited synthetic ability for the formation of the amide linkage and phosphorylation of the $4^{\prime}$-hydroxy group of pantothenic acid (46). Thirdly, there were detectable levels of pantothenoyl-Lcysteine decarboxylase in A. suboxydans $(40,46)$, ‥ bulgaricus (48), and a mutant strain from $\underline{L}$. helveticus (48). The pantothenoyl-L-cysteine decarboxylase was found to be 


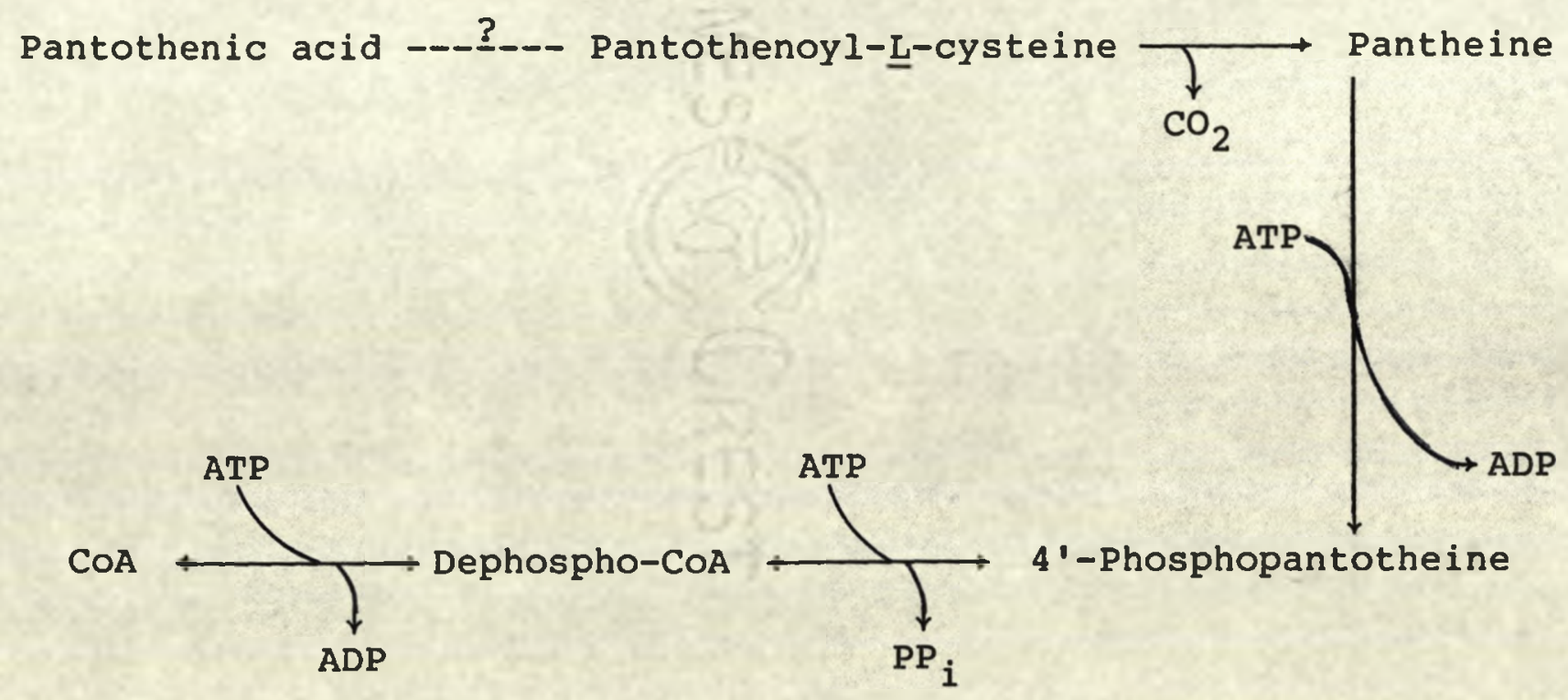

Figure 3. Alternate pathway of biosynthesis of COA. 
associated with the particulate matter after $100,000 \times \mathrm{g}$ centrifugation (48). Lastly, it has been stated above that pantothenic acid kinase can phosphorylate pantetheine, but if the alternate pathway should function to form COA, the enzyme necessary for the formation of pantothenoyl-L-cysteine from pantothenic acid remains to be demonstrated.

\section{Vertebrates}

The biosynthetic pathway for the formation of COA appears to follow the pathway proposed by ward (38) and Brown (43) which is shown in Figure 2, page 18. The elucidation of the pathway for animals was riddled with ambiguities until purified enzymes from rat liver appeared to provide clear-cut evidence of the assembly process.

During the earlier work on the structural identification of COA, it was demonstrated that synthetic pantetheine could be converted to $C O A$ in the presence of ATP and pigeon liver extract (16). Using fresh liver extracts, it was found that pantetheine kinase could be precipitated with protamine sulfate (49). The enzyme had a requirement for $\mathrm{Mg}^{+2}$ and ATP. Pantetheine, after enzymatic treatment, could be converted to COA by enzymes in the protamine supernatant fraction. When the product of the enzymatic treatment was exposed to prostate phosphomonoesterase, the product could not be converted to COA. Using synthetically derived phosphate esters of pantetheine, only the $\underline{D}(+) 4^{\prime}$-phosphopantetheine isomer was 
convertible to $\operatorname{COA}(49)$. At a $\mathrm{pH}$ optimum of 6.5 , it was suggested that pantetheine kinase converted pantetheine to 4 '-phosphopantotheine.

Hoagland and Novelli (50) continued to study the biosynthesis of COA using hog liver as a convenient source of enzymes. They adsorbed pantetheine kinase and ATPase on calcium phosphate gel; and with ammonium sulfate fractionation, they were able to purify dephospho-CoA pyrophosphorylase and dephospho-COA kinase 100- and 125-fold, respectively (50). Dephospho-COA pyrophosphorylase catalyzed the reaction of $4^{\prime}$-phosphopantetheine $+\mathrm{ATP}+\mathrm{Mg}^{+2} \leftrightarrow$ dephospho-COA + $\mathrm{PP}_{i}$, and dephospho-COA kinase catalyzed the reaction of dephospho-COA $+\mathrm{ATP}+\mathrm{Mg}^{+2} \rightarrow \mathrm{COA}+\mathrm{ADP}$. Both enzymes required the substrates to be in the reduced (thiol) form. The formation of dephospho-COA (catalyzed by dephospho-COA pyrophosphorylase) has been shown to be freely reversible by the dismutative formation of COA from dephospho-COA and inorganic pyrophosphate with the coupled enzyme system of the phosphorylase and kinase $(50)$.

Hoagland and Novelli (50) showed that fresh rat liver could synthesize pantetheine from pantothenic acid in the presence of ATP and cysteine with the intermediate formation of pantothenoyl-L-cysteine that was decarboxylated. This information and the existence of pantetheine kinase (49) allowed Hoagland and Novelli to propose the pathway for COA 
biosynthesis in mammalian tissues to be that shown in Figure 3, page 21 .

Brown (43), during his work on the COA pathway in bacteria, also examined the pathway in rat liver and kidney extracts. Using saturated ammonium sulfate, Brown was able to separate pantothenic acid kinase from 4'-phosphopantothenoyl-L-cysteine synthetase, the "coupling enzyme". The "coupling enzyme" could only use 4'-phosphopantothenic acid as a substrate to condense with cysteine. Although any nucleotide triphosphate could be used during the condensation step, ATP was preferred; the bacterial system had a strict requirement for CTP. The rat liver and kidney extracts contained 4'-phosphopantothenoyl-L-cysteine decarboxylase activity for the formation of 4'-phosphopantetheine and could not decarboxylate pantothenoyl-L-cysteine. Brown (43) pointed out that the analytical techniques employed by Hoagland and Novelli (50) could not distinguish between pantetheine and 4'-phosphopantetheine since they were using crude preparations contaminated with pantothenic acid kinase. since it was found that rat liver and kidney extracts contained no enzyme for the decarboxylation of pantothenoyl-L-cysteine, it was concluded that the $C O A$ pathway shown in Figure 2, page 18, was the major pathway functioning in animals for COA (43). However, Cavallini et al. (51) using pigeon liver extracts, suggested another sequence for the assembly of COA: 
pantothenic acid $\rightarrow$ pantothenoyl-L-cysteine $\rightarrow$ 4'-phosphopantothenoyl-L-cysteine $\rightarrow$ 4'-phosphopantetheine $\rightarrow$ COA. The reaction sequence suggests $4^{\prime}$-phosphopantothenoyl-Lcysteine was a better precursor than pantothenoyl-L-cysteine for formation of $C O A$; but their observations disagreed with that point. They explained the observation by assuming that pantothenoyl-L-cysteine in some way inhibits the conversion of $4^{\prime}$-phosphopantothenoyl-L-cysteine to COA, but they did not check this point. These workers did not test pantothenic acid as a substrate for their kinase, but as it was shown later, both pantothenic acid and pantothenoyl-L-cysteine could be phosphorylated (53). Wang and Kaplan (53) demonstrated that pigeon liver extracts contained kinase activity for the conversion of dephospho-COA to COA.

The pathway for COA biosynthesis shown in Figure 2, page 18, was confirmed and clarified through the properties of the synthetic enzymes isolated and purified from rat liver.

Pantothenic acid kinase has been purified about 700-fold over crude extracts by a combination of step-wise procedures that included fractional precipitation with protamine, $\mathrm{pH}$ fractionation DEAE-Sephadex A-50 chromatography, and Sephadex G-200 gel filtration $(52,54)$. The kinase was found to be a very labile enzyme which was successfully purified by stabilization with ATP ( $1 \mathrm{mM}$ ) and 10 percent sucrose at pH 5.8 (54). Although not competely homogenous, the preparation was free from ATPase and phosphatase activities which 
would have interfered during the kinetic and substrate specificity studies.

The kinase requires ATP $-\mathrm{Mg}^{+2} \quad 1: 1$ complex as an active substrate. It has an apparent $k_{m}$ (Michaelis constant) for $\underline{D}-$ pantothenic acid of $0.011 \mathrm{mM}$ and $1 \mathrm{mM}$ for $\mathrm{ATP}-\mathrm{Mg}^{+2}$ at the $\mathrm{pH}$ optimum 6.1 (54). The rat liver pantothenic acid kinase shows broad substrate specificity by the ability to phosphorylate pantothenic acid, pantetheine, pantothenoyl-L-cysteine (52), and pantothenyl alcohol (55) at similar rates. These phosphorylating activities of the kinase should explain the conversion of pantetheine and pantothenoyl-L-cysteine to CoA observed by Hoagland and Novelli (50). Although pantothenyl alcohol can be phosphorylated by the kinase, it is probably first converted to pantothenic acid by liver alcohol dehydrogenase before use as a COA precursor (55). The D-configuration of the $2^{\prime}$-hydroxy form of pantothenic acid was a strict requirement as neither L-pantothenic acid nor $2^{\prime}$-ketopantetheine were substrates of the kinase (54). Pantothenic acid kinase from rat liver was inhibited to various extents by intermediates in the COA pathway, of which 4'-phosphopantetheine and $\mathrm{COA}$ are the most potent inhibitors; 50 percent inhibition at $0.25 \mathrm{mM}(54)$. Pantothenic acid kinase purified from $\underline{B}$. ammoniagenes showed properties similar to rat liver pantothenic acid kinase (40), but the bacterial source appeared to be a much richer source of the enzyme. 
The condensation reaction between $4^{\prime}$-phosphopantothenic acid and L-cysteine is catalyzed by $4^{\prime}$-phosphopantothenoyl-Lcysteine synthetase in the presence of $\mathrm{Mg}^{+2}$ and ATP to form 4'-phosphopantothenoyl-L-cysteine $(52,56)$. The mechanism is similar to the non-ribosomal formation of a peptide bond as in glutamine and glutathione synthesis which involve an activation step (56). The synthetase has been purified 120-fold over crude extracts from rat liver by protamine treatment, ammonium sulfate fractionation, calcium phosphate gel treatment, repeated chromatography on CM-Sephadex C-50, and Sephadex G-75 gel filtration $(52,56)$. Complete separation of the synthetase from pantothenic acid kinase was achieved by protamine treatment (52). The purified preparation was free of inorganic pyrophosphatase, adenylate kinase, and phosphatase thereby rendering an enzyme suitable for a stoichiometric study. The stoichiometric study of the synthetase reaction showed equimolar amounts of ADP, inorganic phosphate, and 4'-phosphopantothenoyl-L-cysteine accompanied by an equimolar decrease in $4^{\prime}$-phosphopantothenic acid (56).

The synthetase has a molecular weight of approximately 37,000 . The $K_{m}$ value of the synthetase is 0.071 to $0.083 \mathrm{mM}$ for $4^{\prime}$-phosphopantothenic acid at the optimal pH of 7.5 (52). Pantothenic acid could not be substituted in this reaction and its presence did not inhibit the rate of the condensation reaction. The synthetase requires $\mathrm{Mg}^{+2}$ for $\mathrm{its}$ action, and 
it was inhibited 50 percent by potassium chloride (KCl) and sodium chloride ( $\mathrm{NaCl}$ ) at $0.05 \mathrm{M}$, and completely by ethylenediamine tetracetic acid (EDTA) at $1 \mathrm{mM}$ and phosphate at $0.08 \mathrm{M}(52)$.

4 '-phosphopantothenoyl-L-cysteine is decarboxylated to 4 '-phosphopantetheine by the enzyme 4'-phosphopantothenoylL-cysteine decarboxylase. The decarboxylase has been purified 110-fold from crude rat liver extracts by ammonium sulfate fractionation, calcium phosphate gel treatment, and DEAE-cellulose chromatography after aging in the cold for three weeks (57). This preparation was free of phosphatase activity.

The $\mathrm{K}_{\mathrm{m}}$ for $4^{\prime}$-phosphopantothenoyl-L-cysteine is $0.133 \mathrm{mM}$ to $0.15 \mathrm{mM}$ at the optimal $\mathrm{pH}$ of 8.0 (57). Pantothenoyl-Lcysteine cannot be substituted as the substrate for the decarboxylase and this compound has no effect on the favored reaction. Although the decarboxylase cannot remove the carbon dioxide group from pantothenoyl-L-cysteine, it can, to a minor extent, remove the carboxyl moiety from dephospho- $\alpha-$ carboxy-COA and $\alpha$-carboxy-COA (58). Dephospho- $\alpha$-carboxy-COA is the hypothetical intermediate if $4^{\prime}$-phosphopantothenoylL-cysteine instead of 4'-phosphopantetheine were linked to the $5^{\prime}$-phosphoadenosine fragment. Dephospho- $\alpha$-carboxy-COA could not be formed when partially purified dephospho-CoA pyrophosphorylase was incubated with $4^{\prime}$-phosphopantothenoylL-cysteine and ATP (58). 
The purified decarboxylase was activated by cysteine or glutathione suggesting a sulfhydryl group function in the active site of the enzyme (57). Neither $\mathrm{Mg}^{+2}$ nor any other cofactors are required for decarboxylase activity. Although pyridoxal and pyridoxal phosphate inhibit the decarboxylase reaction (57), no requirement for pyridoxal could be demonstrated by dialyzing the enzyme or incubating it with semicarbazide. The reaction product of the decarboxylase, 4'phosphopantetheine, inhibits the reaction competitively with a $K_{i}$ (Michaelis inhibition constant) of $0.43 \mathrm{mM}$. Adenosine triphosphate is also inhibitory, but ADP and AMP have no effect.

Dephospho-COA pyrophosphorylase and dephospho-COA kinase catalyze the pyrophosphate bond formation between 4'phosphopantetheine and 5'-AMP, and the subsequent phosphorylation at the $3^{\prime}-\mathrm{OH}$ of the ribose moiety, respectively $(50,59)$. This sequence leading to $\operatorname{COA}$ is the only freely reversible part in the pathway (50). There has been no report on the separation of these two enzymes. During Hoagland and Novelli's work (50) with hog liver where they purified the enzymes about 100-fold, these activities were contained in the same ammonium sulfate fraction. The purification of the enzyme from the $59,000 \times \mathrm{g}$ supernatant of rat liver has been accomplished by protamine treatment, ammonium sulfate fractionation, calcium phosphate gel treatment, 
column chromatography on CM-cellulose and DEAE-cellulose, and Sephadex G-200, yielding a 248-fold purification of the pyrophosphorylase and a 266-fold purification of the kinase (59). Because the specific activities of the enzymes remained constant throughout the purification procedures, it was speculated that the catalytic activities were contained in the same protein or that the enzyme existed as a bifunctional complex (59). The latter possibility has been maintained, since in the presence of 0.2 percent deoxycholate the kinase activity was lost whereas the pyrophosphorylase activity appears to be stimulated.

The purified enzyme preparation has an optimal $\mathrm{pH}$ of 8 to 10 for the pyrophosphorylase reaction and 10 for the kinase reaction (59). Previously, it was shown that 100-fold purified preparations had pH optima of 7.5 and 9.0 , respectively $(50)$. The apparent $k_{m}$ values of the rat liver pyrophosphorylase were found to be $0.14 \mathrm{mM}$ for $4^{\prime}$-phosphopantetheine and $1 \mathrm{mM}$ for ATP. The $\mathrm{K}_{\mathrm{m}}$ values for the kinase are $0.12 \mathrm{mM}$ for dephospho-COA and $0.36 \mathrm{mM}$ for ATP. The complexed enzymes were found to be highly specific for their respective substrates (59). The pyrophosphorylase could not catalyze the formation of NAD from nicotinamide mononucleotide and ATP, and was thus shown to be distinct from NAD pyrophosphorylase. The kinase cannot phosphorylate NAD to NADP (53). The enzymes from both rat liver and hog liver require $\mathrm{Mg}^{+2}$, cysteine, and reduced substrates $(50,59)$. 
Since the pyrophosphorylase and kinase appear to exist in complex form, the synthetic system for COA production may be more efficient. The close proximity of the catalytic sites to each other can prevent dilution and diffusion of the substrates and products within the cell.

Yeasts

The pathway for the synthesis of COA shown in Figure 2, page 18, is commonly referred to as Brown's pathway for COA synthesis (43). During Brown's investigations of the synthetic pathways in rat liver and $\underline{\underline{P}}$. morgani $\mathbf{i}$ (43), Bakers' yeast

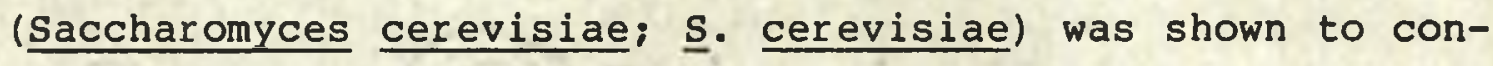
tain pantothenic acid kinase, no coupling activity, but did show decarboxylase activity (43). The investigation stated that the pathway shown in Figure 2, page 18, was likely to operate in an organism if the organism contains at least one of the three enzyme activities (43). Further work using Bakers' yeast for COA synthesis remained dormant until a more economical method for producing commercial COA was needed (44).

Air-dried Bakers' yeast cells were found to accumulate large quantities of $\mathrm{COA}$ from pantothenic acid, cysteine and AMP; however, a better system was found by using B. ammoniagenes cells incubated in the presence of pantothenic acid, cysteine and ATP (44). Further examination of Bakers' yeast cells showed that injured cells in the presence of a cationic 
surfactant were most efficient for the production of CoA (60). It was speculated that the accumulation may have been due to inhibition of enzymes that degradate COA (60), additional extraction of the product due to the detergent by breakdown of permeability barriers $(60)$, or the extraction of enzymes to provide extracellular synthesis of CoA (45).

Most recently, Bucovaz et al. $(61,62)$ have demonstrated a multienzyme complex from Bakers' yeast that contains all the catalytic activities to synthesize CoA, hence the name coenzyme A-synthesizing protein complex (COA-SPC). The multienzyme complex catalyzes the synthesis of CoA from Dpantothenic acid, L-cysteine and ATP. The COA-SPC has been shown to be gradually extracted or solubilized from Bakers' yeast cells by stirring cells, treated beforehand, with ether and dry ice, for a period of 18 hours (63 thru 69). The CoASPC has been purified about 200-fold by precipitating the crude extract with ammonium sulfate followed by sephadex G200 gel permeation chromatography $(63,68,69)$. The gel chromatography demonstrated COA-SPC had an apparent molecular weight in excess of 200,000 , and the presence of $0.02 \mathrm{mM}$ ATP in the elution buffer stabilized the COA-SPC activity $(63,67,68)$. The multienzyme complex theory was advanced by the fact that the complex was shown to give a progressive and corresponding increase in catalytic activity for each of the three substrates as COA-SPC was solubilized $(64,68)$. Also, Sephadex G-200 chromatography (63) and polyacrylamide gel 
electrophoresis (67) showed only one major band of catalytic activity regardless of the substrate. In addition, the temperature and $\mathrm{pH}$ optimum were the same for each catalytic activity.

The finding that $\mathrm{COA}$ was synthesized in Bakers' yeast by a multienzyme complex, led Bucovaz et al. $(61,62,65,66,68)$ to propose a new assembly sequence for the formation of COA. Employing radioactively labeled forms of ATP, D-pantothenic acid, and L-cysteine reaction products were identified by paper chromatography and electrophoretic mobility $(61,62,68)$. The proposed mechanism for the synthesis of COA by COA-SPC is shown in Figure 4. The heavy line represents the multienzyme complex. The initial reaction was believed to be between the B-phospate group of ATP and the 4'-hydroxyl group of D-pantothenic acid resulting in the formation of COA-SPC-bound 5'ADP-4'-pantothenic acid. The $\gamma$-phosphate of ATP was released into the reaction medium. L-Cysteine then reacts through its $\alpha$-amino group with the carboxyl group of the pantothenic acid moiety of the proposed bound 5'-ADP-4'-pantothenic acid. At the time of reaction, cysteine was decarboxylated forming COA-SPC-bound dephospho-COA. Although not shown in Figure 4, dephospho-COA was subsequently phosphorylated and released as COA. The sequence of assembly provides a convenient way to assay the enzymatic activity of COA-SPC $(65,66,68,69)$. The enzyme was incubated in the presence of $D$-pantothenic acid, $A T P$, and $\left[{ }^{35} S\right]-L-c y s t e i n e$ and then, at the end of the 


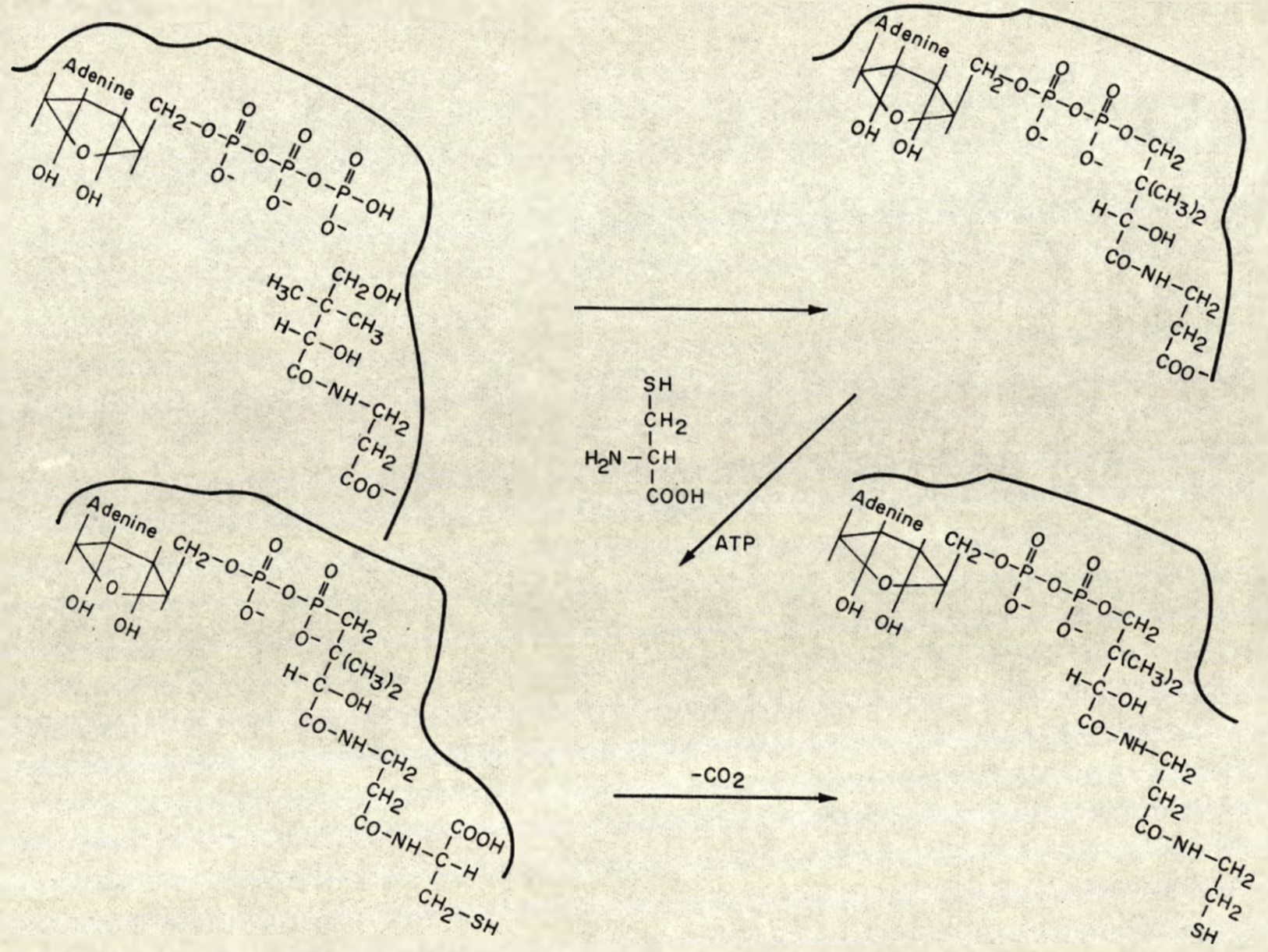

Figure 4. Assembly of dephospho-COA by the coenzyme A-synthesizing protein complex. 
incubation, the protein was precipitated with trichloroacetic acid and collected on a whatman No. 3 MM filter disc. The radioactivity in the collected precipate reflects the amount of dephospho-COA and COA bound to the COA-SPC.

The enzyme for the phosphorylation of dephospho-CoA to form COA was demonstrated to be dephospho-COA kinase. Alkali treatment of COA-SPC recovered from reaction mixtures yielded the intermediate dephospho- $\mathrm{COA}$ and a compound believed to be $5^{\prime}$-ADP-4'-pantothenic acid $(61,62,68)$. Therefore, dephosphoCOA has been shown to be one of the two proposed COA-SPCbound intermediates. It would appear that phosphorylation of COA-SPC-bound dephospho-COA to form COA may in some manner trigger its release from the multienzyme complex.

Inhibition studies of COA-SPC activity by proposed reaction products and compounds with structures related to the reaction products of L-cysteine or D-pantothenic acid supported the reaction sequence shown in Figure 4 (68).

\section{Possible Regulation in the Biosynthesis of Coenzyme $\underline{A}$}

The enzymology studies on the purified enzymes of rat liver have provided some speculation as to the possible regulatory mechanisms involved in the biosynthesis of COA. A scheme for the regulation of $C O A$ synthesis is presented in Figure 5. In rat liver, there appears to be a considerable pool of the COA intermediate 4'-phosphopantetheine, 219 nmoles/gm (70) which corresponds to more than $0.22 \mathrm{mM}$. The 
Pantothenic acid

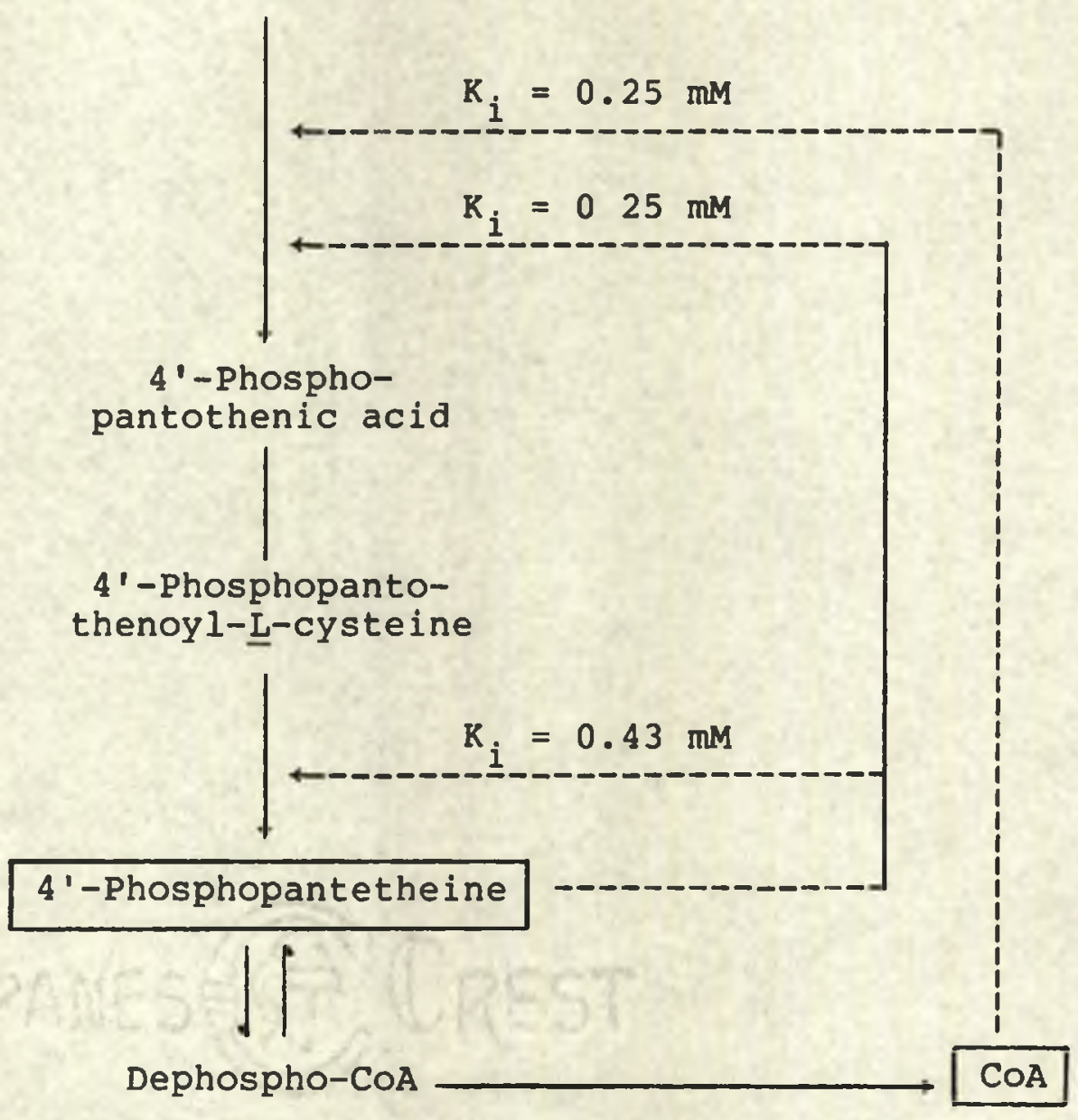

Figure 5. Possible regulation in biosynthesis of COA in the rat liver model. 
COA level in rat liver was 363 nmoles/gm (70), which corresponds to more than $0.36 \mathrm{mM}$. Pantothenic acid kinase was found to be strongly inhibited by 4'-phosphopantetheine and COA at $0.25 \mathrm{mM}(54)$. The liver levels of these two substances are very close to the effective inhibitory concentration, therefore suggesting that the kinase is not fully active in liver cells. A similar inhibition by $C O A$ on purified pantothenic acid kinase from B. ammoniagenes (40) was observed. Although the inhibition was observed, it was contradicted by the fact that this bacterium could accumulate large amounts of $\mathrm{COA}(40)$. Another possible site for the regulation may be 4'-phosphopantothenoyl-L-cysteine decarboxylase which was inhibited by $4^{\prime}$-phosphopantetheine at $0.43 \mathrm{mM}(57)$.

Degradation of Coenzyme $A$ in the Cell

Degradation of COA by cellular enzymes had been recognized early, during the structural elucidation of $\operatorname{COA}(5,29)$. The preoccupation with structure analyses and biosynthetic mechanisms has left the cellular degradative mechanisms virtually untouched until recently.

Rat liver homogenates were found to degrade COA rapidly, however, centrifugation at $100,000 \times \mathrm{g}$ could separate the degradative activity from the synthetic activity (71). COA was found to be first degraded to dephospho-COA by a nonspecific lysosomal acid phosphatase which was identified 
through the use of known inhibitors of lysosomal acid phosphatase (72). Inorganic phosphate, L-tartrate, and fluoride were found to strongly inhibit the dephosphorylation of COA. Dephospho-COA was found to be degraded by an enzyme insensitive to phosphate inhibition (72). The pyrophosphate bond cleavage to the products $4^{\prime}$-phosphopantetheine and $5^{\prime}$-AMP was catalyzed by the action of a nucleotide pyrophosphatase, sometimes referred to as dephospho-COA pyrophosphatase (73). The pyrophosphatase activity was found to be located in nuclear and microsomal fractions of rat liver, and particularly concentrated on the "plasma" membrane of those subcellular fractions (73). At the pH optimum of 7.8 , the pyrophosphatase has a $K_{m}$ value of $0.03 \mathrm{M}$ for dephospho-COA and $0.3 \mathrm{mM}$ for COA. This order of magnitude difference in reactivity suggests that the presence of the phosphate group of the $3^{\prime}$-hydroxyl position on the ribose moiety affords COA protection from action of the pyrophosphatase by sterically hindering access to the active site $(73,74)$. Particularly of interest was the fact that $\mathrm{NADH}$ strongly inhibited $\left(\mathrm{K}_{i}=4 \mu \mathrm{M}\right)$ the enzyme as did ATP and ADP $\left(K_{i}=0.02 \mathrm{mM}\right)$. Moderate inhibition was shown using $5^{\prime}-\mathrm{CTP}, 5^{\prime}$-AMP, and flavin adenosine dinucleotide (FAD) at $k_{i}$ of $0.1 \mathrm{mM}$ (73). Properties that differentiated the nucleotide pyrophosphatase activity from inorganic pyrophosphatase activity were that EDTA completely inhibited nucleotide pyrophosphatase, but inorganic pyrophosphate had little effect on nucleotide pyrophosphatase 
(73). Also, the pH optima of the two enzymes were different (73)

The 4'-phosphopantetheine product formed by the action of nucleotide pyrophosphatase may undergo dephosphorylation to pantetheine prior to degradation by the pantetheinesplitting enzyme, pantetheinase $(75,76)$. Pantetheinase has been highly purified from horse kidney (75) by procedures that included heat fractionation at $60^{\circ} \mathrm{C}$, centrifugation, ammonium sulfate precipitation, CM-cellulose chromatography, DEAE-cellulose chromatography, and zone electrophoresis. The enzyme was found to be highly specific for pantetheine and did not hydrolyze any other carboamide bonds such as those in B-alanylcysteamine and pantothenic acid, but it can hydrolyze only to a minor extent $4^{\prime}$-phosphopantetheine (75). Likewise, pantetheine was shown not to be hydrolyzed by some proteases (73). Although pantothenic acid was not hydrolyzed, it was found to show product inhibition of the pantetheinase reaction and therefore, could possibly be a regulatory point in the degradative pathway. At the $\mathrm{pH}$ optimum of 5 , substrate inhibition was shown by pantetheine (73). The other product of the pantetheinase reaction was shown to be cysteamine ( $\beta$ mercaptoethylamine). Cysteamine cannot be split off from CoA or dephospho-COA as these nucleotides are not substrates for pantetheinase (74).

Pantetheinase contains at least one active site thiol group as shown by the ability for mercaptoethanol and 
dithiothreitol to activate the enzyme, and iodoacetamide to inactivate the enzyme (75). Investigations of the intracellular distributions of pantetheinase in rat liver and kidney have shown that the activity was exclusive in the microsomal-lysososomal fraction in rat liver, and was distributed to both the soluble and microsomal-lysosomal fractions in the kidney (76). Both the liver and kidney enzymes were activated by cysteine. The liver pantetheinase was found highly specific for pantetheine, but the kidney enzymes could hydrolyze pantetheine and to a lesser extent $4^{\prime}$-phosphopantetheine (76).

The combined evidence for the degradation of COA in animals has shown that pantothenic acid and cysteamine are the final products. A summary of the degradative pathway is shown in Figure 6 . The degradative pathway could be a means to dissimilate $4^{\prime}$-phosphopantetheine for the conversion of apo-fatty acid synthetase to holo-fatty acid synthetase (77). Since no enzyme exists for the decarboxylation of cysteine to cysteamine, the degradative pathway for COA could provide the mechanism for cysteamine production and subsequent oxidation to hypotaurine $(78,79)$.

\section{Functional Group of Coenzyme $A$}

The discovery of $\mathrm{COA}$ (1) not only bestowed a metabolic function to pantothenic acid, but also a new bond for the transfer of certain metabolic intermediates (80). Good 


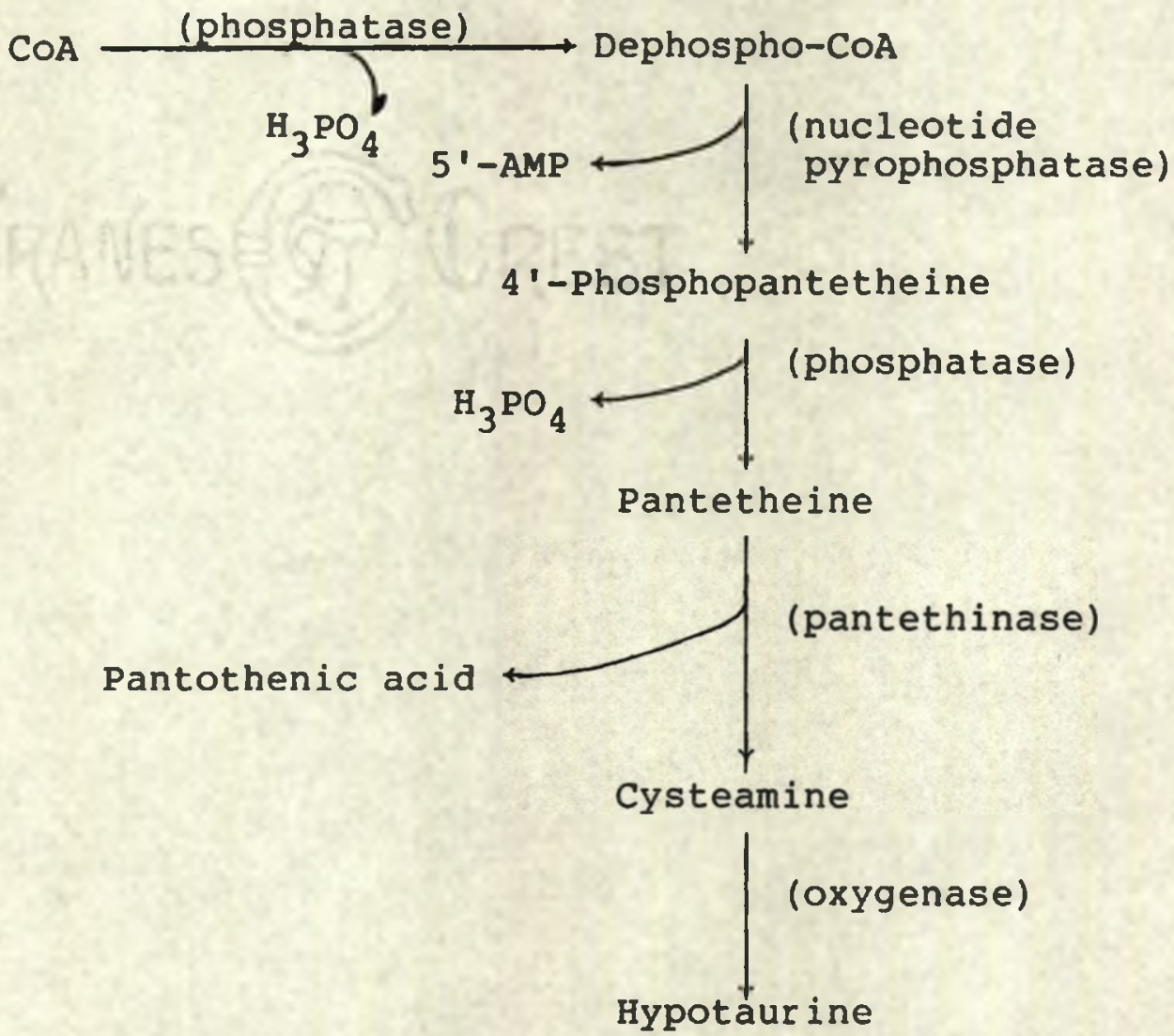

Figure 6. Possible pathway for the degradation of COA. 
evidence has been presented that the terminal thiol group is the reactive center of the COA molecule $(80)$. Originally, a partially purified pantothenic acid derivative from yeast appeared to be acetyl-COA (81). Proof that the acetyl group was bonded to the sulfhydryl of COA was shown by several characteristics: (1) sodium nitroprusside color reaction was indicative of an acetylmercaptan (80); (2) lability of acetylmercaptans upon treatment with mercury salts was demonstrated; (3) the maintenance of activity following treatment with iodoacetate was attributed to the protection afforded the sulfhydryl group by the acetate; (4) on mild alkaline hydrolysis sulfhydryl was liberated and the acetylating ability was lost; and (5) changes in the ultraviolet absorbance at $233 \mathrm{~m} \mu(80)$. These characteristics confirmed the belief that a thioester bond existed and the name "active acetate" was given to acetyl-COA (81). The thioester bond chemically resembles acid anhydrides $(80)$, and therefore has a high energy of hydrolysis, on the order of $-8,000 \mathrm{cal} / \mathrm{mole}$. The thioester bond is far more reactive than the corresponding oxyester bond.

Extensive investigations have led to the discoveries that $\mathrm{COA}$ is involved in many biological functions. For example, two carbon units are transferred as acetyl-CoA in fatty acid oxidation, in the formation of citric acid from oxaloacetic acid, and by combining with itself to form ketone bodies. More complex carboxylic acids can form thioesters 
43

with COA during the synthesis of long chain fatty acids and triglycerides. Table I (76) shows the known metabolic reartrons involving $C O A$ and acyl carrier protein which depicts the central role that these compounds play in cellular metaholism. 
TABLE I

REACTIONS INVOLVING COA AND ACYL CARRIER PROTEIN*

\begin{tabular}{|c|c|c|}
\hline & Reaction & Enzyme \\
\hline & & Oxidor eductase \\
\hline 1. & Aldehyde + COA $+\mathrm{NAD}=\operatorname{acetyl-COA}+\mathrm{NADH}_{2}$ & Aldehyde dehydrogenase \\
\hline 2. & Glyoxylate + COA $+\mathrm{NADP}=$ oxalyl-COA $+\mathrm{NADPH}_{2}$ & Glyoxylate dehydrogenase \\
\hline 3. & $\begin{array}{l}\text { Malonate semialdehyde }+\mathrm{COA}+\mathrm{NAD}(\mathrm{P})= \\
\text { acetyl-COA }+\mathrm{CO}_{2}+\mathrm{NAD}(\mathrm{P}) \mathrm{H}_{2}\end{array}$ & $\begin{array}{l}\text { Malonate semialdehyde } \\
\text { dehydrogenase }\end{array}$ \\
\hline 4 & $\mathrm{RCO}-\mathrm{COOH}+\mathrm{COA}+\mathrm{NAD}=\mathrm{RCO}-\mathrm{COA}+\mathrm{CO}_{2}+\mathrm{NADH}_{2}$ & $\begin{array}{l}\text { Branched chain a-keto acid } \\
\text { dehydrogenase }\end{array}$ \\
\hline 5. & $\begin{array}{l}\text { Butyryl-CoA + oxidized cyt } c=\text { crotonyl-CoA } \\
\quad+\text { reduced cyt } c\end{array}$ & Butyryl-CoA dehydrogenase \\
\hline 6. & $\begin{array}{l}\text { Acyl-COA + oxidized cyt } c=2,3 \text {-dehydroacyl- } \\
\text { COA }+ \text { reduced cyt } c\end{array}$ & Acyl-COA dehydrogenase \\
\hline 7. & $\begin{array}{l}\text { Acetoacetyl-ACP }+\mathrm{NADPH}_{2}=\text { B-hydroxybutyryl- } \\
\text { ACP }+\mathrm{NADP}\end{array}$ & B-Ketoacyl-ACP reductase \\
\hline 8. & $\mathrm{RCH}-\mathrm{CHCO}-\mathrm{ACP}+\mathrm{NADPH}_{2}=\mathrm{RCH}_{2} \mathrm{CH}_{2} \mathrm{CO}-\mathrm{ACP}+\mathrm{NADP}$ & $\begin{array}{l}\text { Enoyl-ACP reductase } \\
\text { Transferase }\end{array}$ \\
\hline 9. & $\begin{array}{l}\text { Methylmalonyl-CoA }+ \text { pyruvate = propionyl-CoA } \\
\quad+\text { oxalacetate }\end{array}$ & $\begin{array}{l}\text { Methylmalomyl-CoA carboxyl- } \\
\text { transferase }\end{array}$ \\
\hline 10. & $\begin{array}{l}\text { Acetyl-CoA }+ \text { L-glutamate }=\operatorname{COA}+\underline{N} \text {-acetyl- } \\
\text { L-glutamate }\end{array}$ & Aminoacid acetyltransferase \\
\hline 11. & $\begin{array}{l}\text { Acetyl-CoA + imidazole }=\mathrm{COA}+ \\
\mathrm{N}-\text { acetylimidazole }\end{array}$ & Imidazole acetyltransferase \\
\hline
\end{tabular}


TABLE I (continued)

\begin{tabular}{|c|c|c|}
\hline & Reaction & Enzyme \\
\hline 12. & $\begin{array}{l}\text { Acetyl-CoA + 2-amino-2-deoxy-D-glucose=CoA }+ \\
2 \text {-acetamido-2-deoxy-D-glucose }\end{array}$ & Glucosamine acetyltransferase \\
\hline 13. & $\begin{array}{l}\text { Acetyl-CoA }+2 \text {-amino-2-deoxy-D-glucose } \\
6-\text { phosphate }=\text { COA }+2 \text {-acetamido-2- } \\
\text { deoxy- -glucose 6-phosphate }\end{array}$ & $\begin{array}{l}\text { Glucosamine phosphate acetyl- } \\
\text { transferase }\end{array}$ \\
\hline 14. & $\begin{array}{l}\text { Acetyl-CoA }+ \text { arylamine }=\text { COA }+\underline{N} \text {-acetylaryl- } \\
\text { amine }\end{array}$ & Arylamine acetyltransferase \\
\hline 15. & Acetyl-COA + choline $=\operatorname{COA}+\underline{0}-$ acetylcholine & Choline acetyltransferase \\
\hline 16. & $\begin{array}{l}\text { Acetyl-CoA + carnitine }=\operatorname{COA}+\underline{o}-\operatorname{acety} 1- \\
\text { carnitine }\end{array}$ & Carnitine acetyltransferase \\
\hline 17. & $\begin{array}{l}\text { Palmityl-CoA + carnitine = palmitylcarnitine } \\
\quad+\text { COA }\end{array}$ & Carnitine palmityltransferase \\
\hline 18. & $\begin{array}{l}\text { Acyl-CoA }\left(<C_{10}\right)+\text { carnitine }=\text { COA }+ \\
\text { acylcarnithe }\end{array}$ & Carnitine acyltransferase \\
\hline 19. & $\begin{array}{l}\text { Acetyl-COA }+ \text { orthophosphage }=\text { COA }+ \\
\text { acetylphosphate }\end{array}$ & Phosphate acetyltransferase \\
\hline 20. & $\begin{array}{l}\text { Acetyl-COA }+\operatorname{acety} l-\operatorname{CoA}=\operatorname{CoA}+\text { acetoacetyl } \\
\operatorname{CoA}\end{array}$ & Acetyl-CoA acetyltransferase \\
\hline 21. & Acetyl-COA $+\mathrm{H}_{2} \mathrm{~S}=\mathrm{COA}+$ thioacetate & $\begin{array}{l}\text { Hydrogen sulfide acetyltrans- } \\
\text { ferase }\end{array}$ \\
\hline 22. & $\begin{array}{l}\text { Acetyl-CoA + thioethanolamine }=\operatorname{COA}+ \\
\text { s-acetylthioethanolamine }\end{array}$ & $\begin{array}{l}\text { Thioethanolamine acetyltrans- } \\
\text { ferase }\end{array}$ \\
\hline 23. & $\begin{array}{l}\text { Acetyl-CoA + dihydrolipoate }=\text { COA }+ \\
\text { 6- } \underline{-}-\text { acetylhydrolipoate }\end{array}$ & Lipoate acetyltransferase \\
\hline 24. & Acetyl-COA + glycine $=\operatorname{COA}+\underline{N}$-acetylglycine & Glycine acetyltransferase \\
\hline
\end{tabular}


TABLE I (continued)

\begin{tabular}{|c|c|c|}
\hline & Reaction & Enzyme \\
\hline 25. & $\begin{array}{c}\text { Phenylacetyl-COA }+\mathrm{L}-g \text { lutamine }=\text { COA }+ \\
\alpha-\underline{N}-\text { phenylacety } 1-L-g l u t a m i n e\end{array}$ & $\begin{array}{l}\text { Glutamine phenylacetyltrans- } \\
\text { ferase }\end{array}$ \\
\hline 26. & $\begin{array}{l}\text { Acyl-CoA }+\mathrm{L}-\text {-glycerol } 3 \text {-phosphate }=\text { COA }+ \\
\text { monoglyceride phosphate }\end{array}$ & $\begin{array}{l}\text { Glycerophosphate acyltrans- } \\
\text { ferase }\end{array}$ \\
\hline 27. & $A c y l-C O A+\operatorname{acetyl-COA}=\operatorname{CoA}+3-o x o a c y l-C O A$ & Acetyl-CoA acyltransferase \\
\hline 28. & $\begin{array}{l}\text { Acetyl-CoA }+ \text { L-aspartate }=\operatorname{CoA}+\underline{N}-\operatorname{acety} 1- \\
\quad \text {-aspartate }\end{array}$ & Aspartate acetyltransferase \\
\hline 29. & $\begin{array}{l}\text { Acetyl-CoA }+B-D-g a l a c t o s i d e=C o A+ \\
6-\text { acetyl-B-D-galactoside }\end{array}$ & Galactoside acetyltransferase \\
\hline 30. & $\begin{array}{l}\text { Butyryl-COA }+ \text { or thophosphate }=\text { COA }+ \\
\text { butyrylphosphate }\end{array}$ & Diglyceride acyltransferase \\
\hline 31. & $\begin{array}{l}\text { Acyl-CoA }+1,2-d i g l y c e r i d e=C O A+ \\
\quad \text { triglyceride }\end{array}$ & Diglyceride acyltransferase \\
\hline 32. & $\begin{array}{l}\text { Acetyl-COA + propionate = acetate }+ \\
\text { propionyl-COA }\end{array}$ & Propionate CoA-transferase \\
\hline 33. & $\begin{array}{l}\text { Succinyl COA + oxalate = succinate + oxalyl- } \\
\text { COA }\end{array}$ & Oxalate COA-transferase \\
\hline 34. & Acetyl-CoA + malonate $=$ acetate + malonyl-CoA & Malonate CoA-transferase \\
\hline 35. & $\begin{array}{l}\text { Succinyl-COA }+3 \text {-oxoacid }=\text { succinate }+ \\
\text { 3-oxoacyl-COA }\end{array}$ & 3-Ketoacid CoA-transferase \\
\hline 36. & $\begin{array}{l}\text { Succinyl COA }+3-\text {-oxoadipate }=\text { succinate }+ \\
\text { 3-oxoadipyl-COA }\end{array}$ & 3-oxoadipate CoA-transferase \\
\hline 37. & $A \operatorname{cet} y l-C O A+A C P=\operatorname{acetyl-ACP}+\operatorname{COA}$ & Acetyl-COA ACP-transferase \\
\hline 38. & Malonyl-COA $+A C P=\operatorname{malonyl-ACP}+\mathrm{COA}$ & Malonyl-COA ACP-transferase \\
\hline
\end{tabular}


TABLE I (continued)

\begin{tabular}{|c|c|c|}
\hline & Reaction & Enzyme \\
\hline 39. & B-Ketoacyl-COA $+A C P=B-$ ketoacyl-ACP + COA & $\begin{array}{l}\text { B-Ketoacyl-COA ACP-transferase } \\
\text { Hydrolase }\end{array}$ \\
\hline 40. & Acetyl-COA $+\mathrm{H}_{2} \mathrm{O}=\operatorname{COA}+$ acetate & Acetyl-CoA hydrolase \\
\hline 41. & Palmityl-CoA $+\mathrm{H}_{2} \mathrm{O}=\mathrm{COA}+$ palmitate & Palmityl-CoA hydrolase \\
\hline 42. & Succinyl-COA $+\mathrm{H}_{2} \mathrm{O}=\mathrm{COA}+$ succinate & Succinyl-COA hydrolase \\
\hline 43. & $\begin{array}{l}\text { 3-Hydroxyisobutyryl-COA } \\
\text { 3-hydroxyisobutyrate }\end{array}$ & $\begin{array}{l}\text { 3-Hydroxyisobutyryl-CoA hydro- } \\
\text { lase }\end{array}$ \\
\hline 44. & $\begin{array}{l}\text { 3-Hydroxy-3-methylglutaryl-CoA }+\mathrm{H}_{2} \mathrm{O}= \\
\text { COA }+3 \text {-hydroxy-3-methylglutarate }\end{array}$ & $\begin{array}{l}\text { 3-Hydroxy-3-methylglutaryl- } \\
\text { CoA hydrolase }\end{array}$ \\
\hline 45. & Palmityl-ACP $+\mathrm{H}_{2} \mathrm{O}=\mathrm{ACP}+$ palmitate & $\begin{array}{l}\text { Palmityl-ACP hydrolase } \\
\text { Lyase }\end{array}$ \\
\hline 46. & Oxalyl-COA $=$ formyl-COA $+\mathrm{CO}_{2}$ & Oxalyl-CoA decarboxylase \\
\hline 47. & Malonyl-COA $=\operatorname{acetyl-COA}+\mathrm{CO}_{2}$ & Malonyl-CoA decarboxylase \\
\hline 48 & $\begin{array}{l}\text { L-Malate }+\operatorname{COA}=\operatorname{acetyl-COA}+\mathrm{H}_{2} \mathrm{O}+ \\
\text { glyoxylate }\end{array}$ & Malate synthase \\
\hline 49. & $\begin{array}{l}\text { 3-Hydroxy-3-methylglutaryl-CoA }=\text { acetyl-CoA }+ \\
\text { acetoacetate }\end{array}$ & Hydroxymethylglutaryl-CoA lyase \\
\hline 50. & $\begin{array}{l}\text { 3-Hydroxy-3-methylglutaryl-CoA }+\mathrm{COA}= \\
\text { acetyl-CoA }+\mathrm{H}_{2} \mathrm{O}+\text { acetoacetyl-COA }\end{array}$ & $\begin{array}{l}\text { Hydroxymethylglutaryl-CoA } \\
\text { synthase }\end{array}$ \\
\hline 51. & $\begin{array}{l}\text { Citrate }+ \text { CoA }=\text { acetyl-CoA }+\mathrm{H}_{2} \mathrm{O}+ \\
\quad \text { oxaloacetate }\end{array}$ & Citrate synthase \\
\hline
\end{tabular}


TABLE I (continued)

\begin{tabular}{|c|c|c|}
\hline & Reaction & Enzyme \\
\hline 52. & $\begin{array}{l}\mathrm{ATP}+\text { citrate }+\mathrm{COA}=\mathrm{ADP}+\mathrm{P}_{\mathbf{i}}+\text { acetyl-COA}+ \\
\text { oxalacetate }\end{array}$ & $\begin{array}{l}\text { ATP citrate lyase } \\
\text { (citrate cleavage enzyme) }\end{array}$ \\
\hline 53. & $\begin{array}{l}\text { L-3-Hydroxyacyl-COA }=2,3 \text { (or } 3,4 \text { ) -trans- } \\
\text { enoyl-COA }+\mathrm{H}_{2} \mathrm{O}\end{array}$ & Enoyl-CoA hydratase \\
\hline 54. & $\begin{array}{l}\text { 3-Hydroxy-3-methylglutaryl-CoA }=\text { trans-3- } \\
\text { methylglutaryl-COA }+\mathrm{H}_{2} \mathrm{O}\end{array}$ & Methylglutaconyl-COA hydratase \\
\hline 55. & $B-A l a n y l-C O A=\operatorname{acr} y l y l-C O A+\mathrm{NH}_{3}$ & B-Alanyl-CoA ammonia-lyase \\
\hline 56. & $\begin{array}{l}\mathrm{D}-(-)-B-\text { Hydroxybutyryl-ACP }=\text { crotony } 1-\mathrm{ACP}+ \\
\mathrm{H}_{2} \mathrm{O}\end{array}$ & Enoyl-ACP hydratase \\
\hline & & Isomerase \\
\hline 57. & $\begin{array}{l}\text { L-3-Hydroxybutyryl-COA }=\text { D-3-hydroxybutyryl- } \\
\text { COA }\end{array}$ & 3-Hydroxybutyryl-COA epimerase \\
\hline 58. & D-Methylmalonyl-COA = L-methylmalonyl-COA & Methylmalonyl-COA racemase \\
\hline 59. & Vinylacetyl-CoA = crotonyl-CoA & Vinylacetyl-CoA isomerase \\
\hline 60. & Methylmalonyl-COA = succinyl-COA & Methylmalonyl-COA mutase \\
\hline & & $\underline{\text { Lyc }}$ \\
\hline 61. & $\mathrm{ATP}+$ acetate $+\mathrm{COA}=\mathrm{AMP}+\mathrm{PP}_{\mathbf{i}}+$ acetyl-Coa & Acetyl-CoA synthetase \\
\hline 62. & 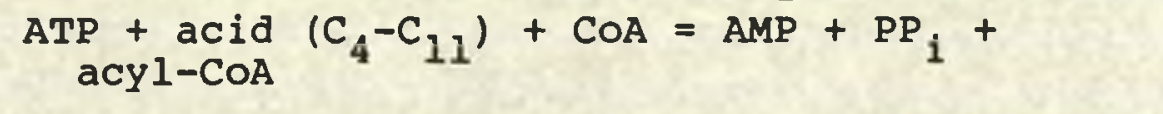 & Acyl-CoA $\left(C_{4}-C_{11}\right)$ synthetase \\
\hline 63. & $\begin{array}{l}\mathrm{ATP}+\operatorname{acid} \\
\operatorname{acy} 1-\operatorname{COA}\end{array}$ & Acyl-CoA $\left(C_{6}-C_{20}\right)$ synthetase \\
\hline
\end{tabular}


TABLE I (continued)

\begin{tabular}{|c|c|c|}
\hline & Reaction & Enzyme \\
\hline 64. & $\mathrm{GTP}+\mathrm{acid}+\mathrm{COA}=\mathrm{GDP}+\mathrm{P}_{i}+\operatorname{acyl-COA}$ & $\begin{array}{l}\text { Acyl-CoA synthetase (GTP- } \\
\text { dependent) }\end{array}$ \\
\hline 65 . & $\underset{\mathrm{COA}}{\mathrm{GTP}}+$ succinate $+\mathrm{COA}=\mathrm{GDP}+\mathrm{P}_{\mathrm{i}}+$ succinyl- & Succinyl-COA synthetase (GDP) \\
\hline 66. & $\begin{array}{l}\mathrm{ATP}+\text { succinate }+\mathrm{COA}=\mathrm{ADP}+\mathrm{P}_{1}+\text { succinyl- } \\
\text { COA }\end{array}$ & Succinyl-COA synthetase (ADP) \\
\hline 67. & $\underset{\text { COA }}{A T P}+$ glutarate $+\mathrm{COA}=\mathrm{ADP}+\mathrm{P}_{\mathbf{i}}+$ glutaryl- & Glutaryl-COA synthetase \\
\hline 68. & $\begin{array}{l}\mathrm{ATP} \\
\text { COA }\end{array}$ & Choloyl-CoA synthetase \\
\hline 69. & $\begin{array}{l}\mathrm{ATP}+\text { acetyl-COA }+\mathrm{CO}_{2}+\mathrm{H}_{2} \mathrm{O}=\mathrm{ADP}+\mathrm{P}_{\mathrm{i}}+ \\
\text { methylmalonyl-COA }\end{array}$ & Acetyl-CoA carboxylase \\
\hline 70. & $\begin{array}{l}\mathrm{ATP}+\text { propionyl-COA }+\mathrm{CO}_{2}+\mathrm{H}_{2} \mathrm{O}=\mathrm{ADP}+ \\
\mathrm{P}_{\mathrm{i}}+\text { methylmalonyl-COA}\end{array}$ & Propionyl-CoA carboxylase \\
\hline 71. & $\begin{array}{l}\mathrm{ATP}+3-\text { methylcrotonoyl-COA }+\mathrm{CO}_{2}+\mathrm{H}_{2} \mathrm{O}= \\
\mathrm{ADP}+\mathrm{P}_{\mathrm{i}}+3 \text {-methylglutaconyl-COA }\end{array}$ & Methylcrotonoyl-COA carboxylase \\
\hline 72. & $\begin{array}{l}\text { Acetyl-ACP }+ \text { malonyl-ACP }=\text { acetoacetyl-ACP }+ \\
\text { ACP }+\mathrm{CO}_{2}\end{array}$ & B-Ketoacyl-ACP synthetase \\
\hline
\end{tabular}


Studies in the laboratory of Dr. E. T. Bucovaz utilizing an economical source of biological material, Bakers' yeast (S. cerevisiae), have revealed the presence of a multienzyme complex which is gradually solubilized into the $105,000 \times \mathrm{g}$ supernatant fraction of cell lysates. The multienzyme complex was found to have the capacity to synthesize coenzyme A from the substrates ATP, D-pantothenic acid and L-cysteine. Concomitantly, a new assembly sequence for coenzyme $A$ was shown to exist. The multienzyme complex was named the coenzyme A-synthesizing protein complex (COA-SPC), because of its catalytic roles. During the elucidation of the new pathway for the synthesis of coenzyme A, a convenient method for the assay for activity of the multienzyme complex was developed. Dephospho-CoA, the intermediate one-step prior to the formation of COA, was found to remain bound to the multienzyme complex. By using a radioactively labeled substrate, measurement of radioactivity bound to the trichloroacetic acid protein precipitate was indicative of COA-SPC activity. The yeast cell lysate is conveniently produced in quantities of $1 \mathrm{~kg}$ to $2 \mathrm{~kg}$ by treatment of whole cells with a 
mixture of diethyl ether and solid carbon dioxide. The CoASPC is insoluble in the yeast cell lysate, and does not display its catalytic activities in an in vitro system until converted to the soluble form. It was observed that stirring the yeast cell lysate for 18 hours at $4^{\circ} \mathrm{C}$ gradually solubilized the COA-SPC. The gradual solubilization of COA-SPC appeared to indicate that the multienzyme complex is either trapped in sub-cellular organelles or bound in some manner to the insoluble components of the yeast cell lysate.

The research described in this dissertation centered around three primary problems which were apparent from the previous investigations on COA-SPC. While working with the preparation of COA-SPC, it appeared advisable to improve the preparation procedure; therefore, the author developed a new method for its preparation. In so doing, it was necessary to study in depth the solubilization characteristics. This study led to the discovery of a low molecular weight compound which functions in the solubilization of COA-SPC. This compound was named t-Factor. The small-scale production of the yeast cell lysate using diethyl ether was satisfactory for this research; however, when a greater quantity of COA-SPC was needed, the danger associated with the use of large quantities of diethyl ether was apparent. Therefore, the author studied and later developed an alternate method of cell lysis which does not require ether, and still provides an enzymatically active COA-SPC. Throughout all of the work described 
here, a greater understanding of the properties and characteristics of COA-SPC was accomplished. A better understanding of COA-SPC is important because of the nature of COA production. The assembly sequence of the substrates for the production of COA is significantly different from those previously reported for other systems. COA-SPC synthesizes dephospho-COA and $\mathrm{COA}$ in an in vitro system; therefore, COASPC provides a method for the production of COA and dephospho-COA whereby both compounds can be radioactively labeled at any desired position in their structure. Furthermore, considerable interest is being shown in the COA-SPC because of its important role in the B-Protein Assay for the detection of cancer. 
Involvement of t-Factor in the Preparation of the Coenzyme Asynthesizing Protein Complex of Bakers' Yeast

Preparation of pellets containing COA-SPC. Three $454 \mathrm{~g}$ cakes of Bakers' yeast (Federal Yeast Corporation, Baltimore, Maryland) were crumbled into a suitable glass vessel. Approximately $2.1 \mathrm{~kg}$ or 3.0 liters of anhydrous diethyl ether (Mallinckrodt Chemical Company, St. Louis, Missouri) were added, followed by the rapid addition of $6 \mathrm{~kg}$ of compressed $\mathrm{CO}_{2}$. The mixture was stirred continuously with a glass rod until all the yeast cells were frozen. The yeast cells were considered frozen when the pasty consistency of the mixture was converted to frozen grains, and when the original brown color of the yeast became a pale clay color. The frozen yeast cell mixture was allowed to thaw at $23^{\circ} \mathrm{C}$ to $24^{\circ} \mathrm{C}$ for seven hours at which time the yeast cells had been converted to a fluid state covered by a layer of ether. The mixture was transferred to a five liter flask and attached to a water aspirator vacuum line. The removal of ether was continued for eight to nine hours during which time the fluid yeast suspension was frozen and thawed one more time. The volume 
of the yeast suspension was approximately $1100 \mathrm{ml}$, but could vary depending upon the water content of the yeast. This suspension is referred to as the crude lysate.

The crude lysate was divided into $250 \mathrm{ml}$ centrifuge bottles and centrifuged at $1,000 \times \mathrm{g}$ for 10 minutes in an International centrifuge maintained at $4^{\circ} \mathrm{C}$. Whole cells and starch from the original blocks of Bakers' yeast were discarded. The remainder of the yeast suspension was divided into $250 \mathrm{ml}$ centrifuge bottles and centrifuged in a Beckman Model J-21 centrifuge using a JA-14 rotor. The centrifuge was maintained at $4^{\circ} \mathrm{C}$ and the suspensions were centrifuged at $10,000 \times \mathrm{g}$ for 30 minutes. The dark brown supernatant liquid that resulted following centrifugation was filtered through glass wool to remove the very prominent fat layer. This yielded approximately $400 \mathrm{ml}$ and was referred to as the crude supernatant.

The pellet material resulting from the above centrifugation step was resuspended in a volume of ice cold deionized water equivalent to the volume of the supernatant removed. This first wash of the pellet material, after centrifugation, was discarded. A second resuspension of the pellet material in $400 \mathrm{ml}$ of ice cold deionized water was divided into centrifuge tubes so that approximately $4 \mathrm{~g}$ of wet pellet material would be produced after centrifugation in a JA-20 rotor at $10,000 \times \mathrm{g}$ for 30 minutes at $4^{\circ} \mathrm{C}$. The wet pellet material could be stored at $-70^{\circ} \mathrm{C}$ for a period up to six months with 
neglible losses in activity. Prior to use, the pellets were thawed at $4^{\circ} \mathrm{C}$.

Preparation of $\underline{t-F a c t o r}$. The crude supernatant provided by the initial centrifugation of the crude lysate described under "Preparation of pellets containing COA-SPC," was a source of t-Factor. Heat fractionation of the crude supernatant liquid was achieved by heating a portion of the crude supernatant liquid in a water bath at $80^{\circ} \mathrm{C}$ for 10 minutes. The coagulated proteins were removed by centrifugation at $10,000 \times \mathrm{g}$ at $4^{\circ} \mathrm{C}$ for 30 minutes. The resulting supernatant liquid had an amber color and was referred to as the heattreated supernatant liquid. Both the crude supernatant liquid and heat-treated supernatant liquid could be stored at $-70^{\circ} \mathrm{C}$.

\section{Assay for CoA-SPC Activity}

Components of the reaction mixture. The reaction mixture contained the following components: 2.76 umoles disodium ATP (Sigma Chemical Company, st. Louis, Missouri), 0.77 umoles calcium salt of D-pantothenic acid (ICN Pharmaceuticals, Cleveland, Ohio), 0.50 umoles L-[ ${ }^{35}$ s]-cysteine (Schwarz/Mann, Orangeburg, New York), 126,000 counts per minute $(\mathrm{cpm}) ; 0.5 \mathrm{ml}$ of buffer containing 50 moles Tris acetate (Tris-hydroxymethyl-aminomethane), pH $7.2 ; 2.5$ mmoles potassium chloride; 5 moles magnesium acetate (all buffer components were purchased from Fischer scientific Company, Fair 
Lawn, New Jersey); $0.05 \mathrm{ml}$ of the supernatant fraction to be tested, and water to a total volume of $1 \mathrm{ml}$. Reaction mixtures without ATP served for background activity. Each assay was run in duplicate.

Incubation of the reaction mixture. The reaction components were added to borosilicate glass test tubes (15 mm $x$ $100 \mathrm{~mm}$ ) in no particular order, except that the enzyme was added prior to the water addition so that the enzyme would be completely rinsed into the tube. The tubes were incubated for one hour in a constant temperature water bath at $36^{\circ} \mathrm{C}$. The reaction was terminated by adding $2 \mathrm{ml}$ of 10 percent trichloroacetic acid (TCA; Fischer Scientific Company, Fair Lawn, New Jersey) at room temperature.

Precipitation procedure. The precipitated protein was further coagulated by heating the tubes in a boiling water bath for five minutes. The tubes were cooled to room temperature prior to collection of the precipitated proteins.

Collection of protein precipitates. The protein precipitates were collected by the use of a 30-port Millipore filtration apparatus (Millipore Corporation, Bedford, Massachusetts) attached to a water aspirator pulling a vacuum of 30 pounds per square inch. Filtration discs $25 \mathrm{~mm}$ in diameter were hand punched from whatman No. 3 MM filter paper (Whatman, Incorporated, Clifton, New Jersey). The filter discs 
were numbered with a No. 2 lead pencil to correspond to the reaction tubes. With the filter discs in place, each tube contents were poured into the appropriate well and the tube rinsed into the well with approximately $2 \mathrm{ml}$ of deionized water at room temperature. Each well was allowed to evacuate and the protein precipitates collected were rinsed four times with approximately $2 \mathrm{ml}$ of deionized water per rinse. Following the washing procedure, the filter discs were removed and dried in an oven at $80^{\circ} \mathrm{C}$.

Determination of Radioactivity

The measurement of $\left[{ }^{35} \mathrm{~S}\right]$ was by liquid scintillation counting using the 14-carbon window of a Nuclear Chicago Mark II liquid scintillation counter that had a counting efficiency of 87 percent. The dried filter discs containing the precipitated proteins were placed into glass scintillation vials (Kimble, Toledo, Ohio) and $4 \mathrm{ml}$ of scintillation liquid was added. The scintillation liquid was that described by Hoskinson and Khorana (82) composed of $4 \mathrm{~g}$, 2,5-diphenyloxazole (PPO), $50 \mathrm{mg}, 1,4$-bis-2-(4-methyl-5-phenyloxazoly1)benzene (dimethyl-POPOP), and toluene to a final volume of one liter. The components for the scintillation fluid were provided by the Fischer Scientific Company, Fair Lawn, New Jersey. 


\section{Calculations}

COA-SPC activity. Duplicate samples were averaged and corrected for background by subtracting the cpm provided by the sample to which no ATP was added. COA-SPC activity was expressed as bound $\left[{ }^{35} S\right]$-dephospho-COA since one mole of cysteine was needed to form one mole of dephospho-COA. The following relationship was used to calculate bound dephosphoCOA:

$(0.50$ umoles) $\times$ (cmp bound to protein precipitates) $(1000 \mathrm{nmoles} / \mu \mathrm{mole})=$ $126,000 \mathrm{cpm}$

nmoles $\left[{ }^{35} \mathrm{~S}\right]$-dephospho-COA bound in one hour at $36^{\circ} \mathrm{C}$.

Specific activity. Specific activity was based on the soluble protein concentration contained in the supernatant liquid following the extraction of COA-SPC from insoluble pellet material. Activity was determined by measuring the nmoles of $\left[{ }^{35} \mathrm{~S}\right]$-dephospho-COA-bound to trichloroacetic acid protein precipitates in one hour at $36^{\circ} \mathrm{C}$. Specific activity was expressed as the nmoles of $\left[{ }^{35} \mathrm{~S}\right]$-dephospho-CoA-bound per milligram of soluble protein per hour.

\section{Determination of Protein}

Soluble protein concentrations from yeast supernatants were estimated by the method of Lowry (83). Aliquots of the yeast supernatant material were diluted seriatim 500- and 1000-fold with $0.1 \mathrm{~N} \mathrm{NaOH}$ so that the color development would be within range of the standard curve. Aliquots, $0.5 \mathrm{ml}$, of 
the diluted supernatant were pipetted into duplicate tubes. Five milliliters of alkaline copper reagent (see page 61) were added to the tubes, after which the components were mixed with a vortex mixer and allowed to stand exactly 10 minutes at room temperature. Following the 10 minute incubation, $0.5 \mathrm{ml}$ of $1 \mathrm{~N}$ Folin-Ciocalteau reagent (Fischer Scientific Company, Fair Lawn, New Jersey) was added and immediately mixed. The reaction mixtures were allowed to develop for exactly 30 minutes during which time the yellow color turned to a blue color. After full color development, the tubes were read in a Klett-Summerson photoelectric spectrophotometer (New York, New York) using a green filter for obtaining the wavelength band of 500 to $570 \mathrm{m \mu}$. Duplicate Klett units were averaged and plotted on a standard curve as average klett units versus bovine serum albumin concentration in $\mathrm{mg} / \mathrm{ml}$ (see "Preparation of protein standards").

Preparation of protein standards. Thirty milligrams of crystalline bovine serum albumin (BSA) (Sigma Chemical Company, st. Louis, Missouri) was placed onto the surface of $30 \mathrm{ml}$ of deionized water. The BSA was allowed to stand at $4^{\circ} \mathrm{C}$ until completely dissolved, then it was transferred to a $100 \mathrm{ml}$ volumetric flask and diluted to exactly $100 \mathrm{ml}$ with deionized water. The concentration of this solution was measured based on the specific absorbance for BSA (84). Using a Gilford Spectrophotometer (Gilford Laboratories, Oberlin, Ohio) with the wavelength set at $280 \mathrm{m \mu}$, the absorbance of 
the BSA solution in a $1 \mathrm{~cm}$ path length quartz cuvette was determined. Deionized water was used as the reagent blank. The relationship that $1 \mathrm{mg} B S A$ per $\mathrm{ml}$ has an absorbance of 0.66 (84) allowed the concentration of the stock BSA solution to be determined:

$$
\mathrm{mg} B S A / \mathrm{ml}=\frac{\text { ABSORBANCE at } 280 \mathrm{~m} \mu}{.66}
$$

Appropriate dilutions with deionized water of the above stock BSA solution were used to make three other protein standards. The other protein standards were checked at $280 \mathrm{~m}$ and their concentrations calculated based on the above relatonship. The standards were stored at $4^{\circ} \mathrm{C}$ with a few milliliters of chloroform to inhibit bacteria growth.

Protein standard curve. The BSA standards were allowed to react with the Lowry Reagents (83) as described above for the soluble yeast protein. A reagent blank was made by replacing BSA with an equivalent amount of deionized water. The reagent blank was not subtracted from either the standards or yeast samples, but was used as a point on the standard curve. Deionized water was used to electronically balance the Klett meter. For each set of yeast protein determinations, a set of standards was used to maintain reliability and compensate for any time dependent decay of Lowry reagents.

Duplicate standards were averaged and plotted on graph paper as average klett units versus BSA $\mathrm{mg}$ per $\mathrm{ml}$. The points 
were fitted to the best straight line using the linear regression program supplied with the Hewlett-Packard table top computer, model 9801A (Hewlett-Packard Corporation, Houston, Texas).

Calculation of protein concentration. The line, generated by the BSA standards supplied a y-intercept value (b) and a slope value (m). By rearranging the equation for a line $y=m x+b$, where $y$ was average klett units and $x$ was protein concentration in $\mathrm{mg} / \mathrm{ml}$, the protein concentration in a diluted yeast sample could be determined. The original concentration could be determined by simply multiplying the diluted soluble yeast protein concentration by the appropriate dilution factor. The calculation is summarized in the following equation:

$$
\begin{gathered}
x(m g \text { soluble yeast protein } / m l)= \\
\frac{Y \text { (average Klett units) }-b(y-\text { intercept })}{m(\text { slope })} \times \text { Dilution factor }
\end{gathered}
$$

Preparation of reagents for protein determinations. The alkaline copper reagent was prepared by mixing the following reagents $(83)$ :

1. $10 \mathrm{ml}$ of $\mathrm{Na}_{2} \mathrm{CO}_{3}-\mathrm{NaOH}$ reagent prepared by dissolving $20 \mathrm{~g}$ of $\mathrm{Na}_{2} \mathrm{CO}_{3}$ and diluting to $100 \mathrm{ml}$ of $1 \mathrm{~N} \mathrm{NaOH}$. The $1 \mathrm{~N}$ $\mathrm{NaOH}$ was prepared by dissolving $40 \mathrm{~g}$ of $\mathrm{NaOH}$ in $1000 \mathrm{ml}$ of deionized water;

2. $90 \mathrm{ml}$ of deionized water; 
3. $2 \mathrm{ml}$ of one percent sodium-potassium tartrate prepared by dissolving $1 \mathrm{~g}$ of the compound in a final volume of $100 \mathrm{ml}$ of deionized water;

4. $2 \mathrm{ml}$ of 0.5 percent of $\mathrm{CuSO}_{4} 5 \mathrm{H}_{2} \mathrm{O}$ prepared by dissolving $0.5 \mathrm{~g}$ of $\mathrm{CusO}_{4} 5 \mathrm{H}_{2} \mathrm{O}$ in a final volume of $100 \mathrm{ml}$ of deionized water;

5. Deionized water was added to the $100 \mathrm{ml}$ mark of a graduate cylinder.

The solution was mixed by pouring back and forth between a beaker and a graduate cylinder. The alkaline copper reagent was stored on ice and considered good until the solution became cloudy. The reagent was made just prior to use and discarded after the last protein sample was assayed. Large volumes of the alkaline copper reagent were obtained by measuring multiple volumes of the above components.

The Folin-Ciocalteau reagent was purchased as a $2 \mathrm{~N}$ solution and diluted one volume of reagent to one volume of deionized water. The solution was good for several months at $4^{\circ} \mathrm{C}$.

All the components for the protein determination reagents were purchased from Fischer Scientific Company, Fair Lawn, New Jersey.

Assay for t-Factor Activity by the Solubilization of COA-SPC The fraction of the soluble portion of the yeast cell to be tested was mixed with washed pellet material described 
under "Preparation of pellets containing COA-SPC" in a volume of $2 \mathrm{ml}$. Larger suspension volumes could be produced as long as the pellet to soluble fraction ratio was maintained. To the suspension was added potassium chloride $(\mathrm{KCl}$; Fischer Scientific Company, Fair Lawn, New, Jersey) so that the concentration was $10 \mathrm{mg} \mathrm{KCl}$ per milliliter of yeast suspension. The mixtures were mechanically agitated at $4^{\circ} \mathrm{C}$ for 18 hours by an overhead stirring motor, magnetic stirring motor, or by rocking on a Buchler shaker (Buchler Instruments, Fort Lee, New Jersey). These conditions were standard except where noted. Following the stirring step, the suspensions were centrifuged at $105,000 \times \mathrm{g}$ at $4^{\circ} \mathrm{C}$ for 20 minutes in a Beckman Model L3-50 (Beckman Instruments, Fort Lee, New Jersey) using the appropriate rotor for the volume of yeast supernatants. Control samples were handled identically, except the t-Factor solution was replaced by deionized water or $0.05 \mathrm{M}$ sodium acetate buffer, $\mathrm{pH} 5.8$. The supernatant produced by the centrifugation step was tested for COA-SPC activity as described under "Assay for COA-SPC Activity."

\section{Alternate Method for the Preparation of t-Factor}

Three $454 \mathrm{~g}$ cakes of fresh Bakers' yeast were crumbled, by hand, into approximately four to five liters of liquid nitrogen. The frozen granules of yeast were thawed by running cold tap water over the outside of the container. The yeast was liquified by this process. The liquified yeast 
was frozen and thawed two more times using liquid nitrogen. The liquified yeast was divided into $250 \mathrm{ml}$ centrifuge bottles and centrifuged at $10,000 \times \mathrm{g}$ for 30 minutes at $4^{\circ} \mathrm{C}$ as described under "Preparation of pellets containing COASPC."

The supernatant was treated as described for the "Preparation of t-Factor." Although t-Factor could be extracted, the pellet material produced by this process was unacceptable for obtaining COA-SPC.

Filtration of the t-Factor through Dialysis Tubing

The t-Factor could be recovered from crude supernatant, heat treated supernatant, and COA-SPC solution obtained following solubilization of the enzyme with the t-Factor by use of vacuum filtration (85). The tubing utilized was size No. 8 (Union Carbide, Chicago, Illinois). The tubing was first rinsed in a $250 \mathrm{ml}$ beaker with ten changes of distilled water. One end of a length of tubing was tied with a double knot. The open end of the tubing was threaded through the hole of a No. 10 rubber stopper. A glass tube with capillary tubing attached was introduced into the dialysis tubing opening and then through the hole in the stopper, thus forming a seal. The tubing was placed into a five liter side arm flask and stopper was fitted in the mouth of the flask. The capillary tubing was placed into a solution of $t$-Factor and the flask was attached to a water aspirator. The vacuum was 
continued until the t-Factor solution no longer entered the dialysis tubing. The connection to the water aspirator was clamped off and stoppered, and the filtration was allowed to continue overnight at $4^{\circ} \mathrm{C}$. A reservoir of $t$-Factor could be situated so that the capillary entry tube was at the bottom of the reservoir, and as dialysis proceeded, solution was replaced inside the dialysis tubing. The fluid passing through the tubing could be stored at $-70^{\circ} \mathrm{C}$ and tested for activity as described under "Assay for t-Factor Activity by the Solubilization of COA-SPC." A smaller apparatus could be used for smaller volumes.

\section{Cone Filtration of t-Factor}

Filtration cones (Amicon Corporation, Lexington, Massachusetts) that retain molecules greater than 25,000 molecular weight (CF 25) were used to fractionate the heat treated supernatant. Filter cones were filled to capacity $(7 \mathrm{ml})$ and centrifuged in an International Centrifuge equipped with a seven inch radius head at $1,000 \times \mathrm{g}$ at $4^{\circ} \mathrm{C}$ for two hours. The filtrate collected was tested for activity as described under "Assay for t-Factor Activity by the solubilization of CoASPC."

Membrane Ultrafiltration of t-Factor

Amicon ultrafiltration membranes of the UM series were used to fractionate the heat treated supernatant liquid containing $t$-Factor. The membranes employed were the UM-2 for 
the retention of compounds greater than 1000 molecular weight and UM-05 for the retention of compounds greater than 500 molecular weight. The membranes, $76 \mathrm{~mm}$ in diameter, were placed into an appropriate stirring cell, and were flushed with approximately $100 \mathrm{ml}$ of deionized water to remove glycerol and trace ultraviolet absorbing material, and to condition the membrane to the pressurized situation. Heat teated supernatant liquid was placed into the cell containing the UM-2 ultrafilter and stirred. The heat treated supernatant was forced through the membrane under 40 pounds per square inch (psi) nitrogen gas. The process was carried out at $4^{\circ} \mathrm{C}$ and the filtrate was collected and stored at $-70^{\circ} \mathrm{C}$. The filtration process was quite slow taking as long as seven days to filter $250 \mathrm{ml}$ of supernatant liquid. When the filtration was completed, the filtrate was tested as described under "Assay for t-Factor Activity by the Solubilization of COA-SPC," and the retentate was diluted to the original volume with deionized water and tested for activity.

When an adequate volume of UM-2 filtrate was collected, the filtrate was subsequently passed through a UM-05 filter. Retained material and the UM-05 filtrate were tested for activity as described under "Assay for t-Factor Activity by the Solubilization of COA-SPC."

Membranes were cleaned for reuse after $200 \mathrm{ml}$ of material had been filtered. The cleaning procedure began with submerging the membrane in a one percent solution of pepsin 
in $1 \mathrm{~N} \mathrm{HCl}$ for several hours at $36^{\circ} \mathrm{C}$. The surface of the membrane was rinsed with $200 \mathrm{ml}$ of five percent sodium chloride (Fischer Scientific Company, Fair Lawn, New Jersey) and then generously with distilled water. The membrane could be immediately reused or stored in 10 percent ethyl alcohol (Mallinckrodt Chemical Company, st. Louis, Missouri) at $4^{\circ} \mathrm{C}$.

\section{Heat Stability of t-Factor}

Aliquots of the UM-05 filtrate, $2 \mathrm{mI}$ in volume, were placed into sealed tubes and heated in a water bath at $80^{\circ} \mathrm{C}$ for a period of 24 hours. At prescribed intervals, a tube was removed and cooled to $4^{\circ} \mathrm{C}$. After the cooling period, tFactor activity was assessed as described under "Assay for $t-$ Factor Activity by the Solubilization of COA-SPC."

\section{Proteolytic Treatment of t-Factor}

A portion of the UM-05 filtrate was lyophilized in $4 \mathrm{ml}$ aliquots to dryness. One aliquot of the filtrate was dissolved in $10 \mathrm{ml}$ of $0.13 \mathrm{M}$ ammonium bicarbonate (Fischer Scientific Company, Fair Lawn, New Jersey), and to this $100 \mathrm{\mu g}$ of trypsin, twice crystallized (worthington Biochemical, Freehold, New Jersey) were added. The $\mathrm{pH}$ of the solution was adjusted to 8.0 with $1 \mathrm{~N} \mathrm{NH}_{4} \mathrm{OH}$ (Mallinckrodt Chemical Company, st. Louis, Missouri). A control sample was prepared in a similar manner, except the trypsin was inactivated by boiling for two minutes prior to its addition to the lyophilized UM-05 filtrate. 
Two additional aliquots were subjected to protease digestion. The protease was purified type VI obtained from Streptomyces griseus (Sigma Chemical Company, St. Louis, Missouri). To one aliquot of the lyophilized filtrate, dissolved in $10 \mathrm{ml}$ of $0.13 \mathrm{M}$ ammonium bicarbonate, $100 \mathrm{\mu g}$ of protease were added and the $\mathrm{pH}$ adjusted to 7.2 with $1 \mathrm{~N} \mathrm{HCl}$ (Mallinckrodt Chemical Company, st. Louis, Missouri). A control for protease was prepared identically, except the enzyme was boiled for two minutes prior to its addition to the lyophilized UM-05 filtrate.

Incubation of the samples. All four samples were incubated for six hours at $37^{\circ} \mathrm{C}$. During the incubation, the $\mathrm{pH}$ was monitored by testing the reaction mixture with $\mathrm{pH}$ paper.

Recovery of samples. Following the incubation period, the enzymatic reactions were terminated by boiling the reaction mixtures for three minutes. Centrifugation was used to remove any denatured debris and the supernatant liquids were filtered through No. 8 tubing at $4^{\circ} \mathrm{C}$ against reduced pressure (see "Filtration of the t-Factor through Dialysis Tubing"). The dialysates were lyophilized to dryness and dissolved in $4 \mathrm{ml}$ of deionized water. The $\mathrm{pH}$ of these solutions were adjusted to $\mathrm{pH} 5.8$ with $1 \mathrm{~N} \mathrm{HCl}$, if necessary.

Assessment of t-Factor. The solutions recovered from the proteolytic enzyme reaction mixtures were mixed with 
pellet material as described under "Assay of t-Factor Activity by the Solubilization of COA-SPC."

\section{Proteolytic Activity Assessment}

Qualitative. The protease detection kit (Bio-Rad Laboratories, Richmond, California), utilizing the principle of radial diffusion in gel (86), was used to qualitatively determine proteolytic activity.

Two agar gel tablets containing casein and $\mathrm{Tr}$ is- $\mathrm{HCl}$ were placed in a $25 \mathrm{ml}$ side arm flask and suspended in $15 \mathrm{ml}$ deionized water. After 15 minutes, the suspension was mixed thoroughly and then heated in a boilng water bath until the agar gel completely dissolved. The agar solution was vacuum aspirated to remove trapped air. The solution was cooled to about $50^{\circ} \mathrm{C}$ and then poured onto glass Petri dishes. After the agar solidified, $4.0 \mathrm{~mm}$ uniform sample wells were punched into the gel. The gel contained approximately one percent casein at $\mathrm{pH} 7.2$. Using a micropipet, the sample wells were filled with 10 to $30 \mu \mathrm{l}$ of solution to be tested for proteolytic activity.

plate incubation. The agar plates were incubated at room temperature $\left(20^{\circ} \mathrm{C}\right.$ to $\left.25^{\circ} \mathrm{C}\right)$ for 16 hours. During the incubation period, the plates were covered to prevent evaporation. 
Detection. At the end of the 16-hour incubation time, the presence of transparent diffusion zones in the opalescent agar around a sample well was indicative of proteolytic activity. The diffusion zones which are indicative of proteolytic digestion of casein were enhanced by overlaying the agar plate with a solution of three percent $(v / v)$ acetic acid (Mallinckrodt Chemical Company, st. Louis, Missouri). After 10 minutes, the plate was rinsed with water. A comparison could be made between identical samples applied to the agar plate in different volumes by measuring the diameter of the diffusion zone.

Controls for diffusion zone visualization. Urokinase provided in the protease detection kit was diluted to 600 units per ml with deionized water. Combined were $30 \mu l$ of the urokinase solution and $30 \mu l$ of a serum sample. The solution was incubated for 15 minutes at $37^{\circ} \mathrm{C}$. Following the incubation period, a $30 \mu \mathrm{l}$ aliquot was removed and applied to a sample well of an agar plate. A sample of the incubation mixture served as the positive control since the plasmin converted from plasminogen is proteolytically active toward casein. A negative control was demonstrated by applying $30 \mu l$ of urokinase to a sample well. Following application, the samples were handled as described under "Plate incubation" and "Detection." Positive and negative controls were utilized on each plate. 
Samples for qualitative detection of proteolytic activity. Samples of t-Factor were tested for proteolytic activity by the gel diffusion method. Samples of the crude supernatant liquid, heat treated supernatant liquid, and UM05 filtrate containing t-Factor as well as COA-SPC solubilized by these fractions were tested for proteolytic activity.

The Effect of the Concentration of t-Factor on the Solubilization of COA-SPC.

The ultrafiltrate provided by the Amicon filtration through the UM-05 membrane (see Membrane Ultrafiltration of t-Factor") was the source of t-Factor for this study. $t-$ Factor was concentrated by lyophilizing $4 \mathrm{ml}$ of the filtrate to dryness and then dissolving the material in $2 \mathrm{ml}$ of deionized water. Dilutions of the $t$-Factor solution were made by taking an appropriate aliquot of the UM-05 filtrate and diluting the material to a total volume of $2 \mathrm{ml}$ with deionized water. The cellular t-Factor concentration was assumed to be that contained in the untreated UM-05 filtrate. Each of the solutions were handled as described under "Assay for t-Factor Activity by the Solubilization of COA-SPC."

\section{Ashing of t-Factor}

The procedure, with slight modifications, for ashing tFactor was that which DeRenzo (88) used for identifying 
molybdenum as the factor that stimulated the level of xanthine oxidase in rat intestine. Two milliliter portions of UM-05 filtrate (see "Membrane Ultrafiltration of t-Factor") were placed in clean, porcelain crucibles (Coors, Boulder, Colorado). The amber fluid was evaporated with a very low flame. The filtrate material charred, and heavy black smoke evolved during the evaporation period. The residue that remained was charred further by increasing the intensity of the flame until the bottom of the crucible was heated to dull red. The crucible was then placed into a small electric muffle furnace (Thermo Electric Mfg. Co., Dubuque, Iowa) and heated for approximately two hours at $800^{\circ} \mathrm{C}$.

Treatment of the ash. After cooling $2 \mathrm{ml}$ of deionized water was added to the white ash and the mixture was mixed thoroughly. All of the ash that remained was not soluble. The suspension was centrifuged in a clinical centrifuge at room temperature and the liquid portion was tested for $t$ Factor activity as described under "Assay for t-Factor Activity by the Solubilization of COA-SPC."

Another portion of the ashed material was suspended in I $\mathrm{N}$ hydrochloric acid to dissolve insoluble oxides of compounds produced during the ashing procedure. Most of the ash was soluble, but the small amount that was insoluble was removed by centrifugation. The acidic ash solution was adjusted to $\mathrm{pH} 5.8$ with $10 \mathrm{~N} \mathrm{NaOH}$ and tested for t-Factor as 
described under "Assay for t-Factor Activity by the Solubilization of COA-SPC."

\section{Paper Chromatography}

Development of preparative chromatograms. Descending paper chromatography of t-Factor was performed on 1 MM whatman paper $(56 \mathrm{~cm} \times 32 \mathrm{~cm})$ at room temperature. Ten milliliters of UM-05 filtrate were lyophilized to dryness and redissolved in $1 \mathrm{ml}$ of deionized water. The total volume was applied in a narrow band onto several sheets of chromatography paper and dried with a stream of warm air.

The chromatograms were allowed to develop for 16 to 18 hours at room temperature.

Chromatographic solvents. The following solvents (88) were used to develop the chromatograms: Solvent I, $\underline{n}-$ butanol:glacial acetic acid:water $(12: 3: 5 \mathrm{v} / \mathrm{v} / \mathrm{v})$; Solvent II, n-butanol:glacial acetic acid:water $(3: 2: 3 \mathrm{v} / \mathrm{v} / \mathrm{v})$. The solvents, prior to development of the chromatogram, were placed in beakers and allowed to saturate the atmosphere of the chromatography chamber. The solvents for the systems were products of Mallinckrodt Chemical Company, st. Louis, Missouri.

Extraction of paper chromatograms. After development, the paper chromatograms were dried until no solvent vapors could be detected. A $1 \mathrm{~cm}$ strip was cut from each side of the 
chromatogram from the origin to the solvent front. These strips were sprayed with ninhydrin independently of the rest of the chromatograms and the migration of ninhydrin positive material was used as markers for segmenting the paper. The chromatograms were cut into segments parallel to the origin at the convenient breaks in the ninhydrin staining (see below, "Detection of separated compounds") materials.

The material on each segment was extracted by placing the paper into a $250 \mathrm{ml}$ bottle containing $100 \mathrm{ml}$ of deionized water at $4^{\circ} \mathrm{C}$. The extraction fluid was removed and replaced with fresh water once during a 24-hour period. Following the 24 hour extraction period at $4^{\circ} \mathrm{C}$, the second portion of extraction fluid was decanted and combined with the fluid of the first extraction. The bottles containing wet, fragmented chromatography paper were centrifuged at $10,000 \times \mathrm{g}$ for 30 minutes to squeeze the remaining water from the chromatography paper. The residual water was combined with the first two extractions and the entire volume was filtered through a Millipore HA $0.45 \mu$ filter to remove paper fibers.

The extracted material from each segment was lyophilized to dryness and dissolved in $10 \mathrm{ml}$ of deionized water for testing as described under "Assay for t-Factor Activity by the Solubilization of COA-SPC."

Qualitative paper chromatography. Purification of $t-$ Factor beyond the UM-05 filtration step was monitored by 
paper chromatography using the developing solution described under "Chromatographic Solvents." Likewise, when it was of interest to know if certain compounds might be contained in a particular segment of a chromatogram, $20 \mu l$ of the authentic compounds dissolved to a concentration of $1 \mathrm{mg} / \mathrm{ml}$ were applied and allowed to migrate in the solvent systems.

Detection of separated compounds. At the end of the developing period for the particular solvent, the chromatograms were removed from the solvent, dried, then the separated compunds were detected by: (1) absorption of ultraviolet (UV) light, (2) color reaction, and (3) radioactivity measurement.

(1) Absorption of UV light. The chromatograms were exposed to a source of UV light $(260 \mathrm{~m} \mu)$ in a darkened room. All compounds containing adenine absorb uV light and can be located.

(2) Color reaction. The chromatograms were sprayed with one of the following solutions:

(a) Five milliliters 60 percent $(w / w)$ perchloric acid, $10 \mathrm{ml}$ of $1 \mathrm{~N}$ hydrochloric acid, $25 \mathrm{ml}$ of four percent $(w / v)$ ammonium molybdate, and water to $100 \mathrm{ml}$. Compounds containing phosphate esters appeared as blue spots when the sprayed chromatograms were heated or exposed to UV light as reported by Hanes and Isherood (89). 
(b) Compounds containing SH-groups or disulfide groups were detected with the nitroprusside spray described by Toennies and Kolb (90). The nitroprusside spray consists of two reagents: (1) $1.5 \mathrm{~g}$ sodium nitroprusside mixed in $5 \mathrm{ml}$ of $2 \mathrm{~N}$ sulfuric acid plus $95 \mathrm{ml}$ methanol plus $10 \mathrm{ml}$ of 28 percent ammonia, then filtered and the collected filtrate was used in the detection of SH-containing compounds; (2) two percent $\mathrm{NaCN}$ in 95 percent methanol was used following nitroprusside treatment to detect disulfide-containing compounds. The chromatograms were dipped in reagent (1) and while still damp were dipped next in reagent (2). The position of compounds containing SH-groups or disulfide groups is indicated by red spots (89).

(c) The ninhydrin spray consisted of $0.5 \mathrm{~g} \mathrm{1,2,3-tri-}$ ketohydrindene in $100 \mathrm{ml}$ acetone (91). Heating the sprayed chromatograms at $75^{\circ} \mathrm{C}$ for one minute caused violet colored spots to appear indicating the position of $\alpha$-amino acids.

(3) Radioactivity measurements. When desired, each dried developed chromatogram was cut into successive segments one-half inch in length, then each segment was placed in a vial and the radioactivity measured as described under "Determination of Radioactivity."

Permeation Chromatography of t-Factor on Sephadex G-10

Preparation of the column. Approximately $50 \mathrm{~g}$ of Sephadex G 10 fine grade with particle size 40-120 $\mu$ (Pharmacia, 
Piscataway, New Jersey), were equilibrated for three hours in approximately twice its volume of deionized water. Following the three hour period, the gel beads were degassed by vacuum. After settling, any super fine material was aspirated away. Part of the equilibration volume was removed so that a smooth slurry remained. A column of bed dimensions $0.9 \mathrm{~cm} \times 163 \mathrm{~cm}$ was prepared, pouring the gel slurry onto a cushion of $20 \mathrm{ml}$ of deionized water. After column packing was complete, a flow rate of $1 \mathrm{ml}$ per minute was maintained with a Buchler peristalic pump (Buchler Instruments, Fort Lee, New Jersey). The column was maintained at room temperature throughout its preparation and usage. Between fractionations the column was treated with $0.001 \mathrm{M}$ EDTA to prevent microbial growth.

The following defined volumes were determined for the column:

$v_{t}=$ total bed volume; calculated by the equation of the volume of a cylinder $V=\pi r^{2} I$;

$v_{0}=$ void volume; by monitoring the elution of the blue dextran (Pharmacia, Piscataway, New Jersey) peak. One milliliter of a solution $2 \mathrm{mg} / \mathrm{ml}$ in blue dextran was applied to the column for this measurement.

Elution method. Ten milliliters of UM-05 filtrate was lyophilized to dryness and redissolved in $1 \mathrm{ml}$ of deionized water. The total volume, plus $0.5 \mathrm{ml}$ rinse were placed onto the column bed surface. When the solution had penetrated the 
bed, the elution was started by supplying deionized water via the peristalic pump at a flow rate of $1 \mathrm{ml}$ per minute. The column could be eluted with $0.03 \mathrm{M} \mathrm{KCl}$ with no difference in elution pattern noted; however, water was the preferred eluent since the additional salt provided by the $\mathrm{KCl}$ could not be conveniently removed. The column was monitored by allowing the effluent to pass through a $1 \mathrm{~mm}$ path length flow cell monitored at $260 \mathrm{~m} \mu$ by a Beckman Acta II Dual Beam spectrophotometer (Beckman Instruments, Fullerton, California). Air was used for the reference beam. In addition to recording the elution pattern at $260 \mathrm{m \mu}, 5 \mathrm{ml}$ fractions were collected in a refrigerated fraction collector.

Assay method. The elution volume $\left(v_{e}\right)$ for $t$-Factor was determined by pooling fractions collected from the column, reducing the volume by lyophilization and redissolving the particular pool to a concentration approximately that applied to the column. Each pool was tested for t-Factor activity as described under "Assay for t-Factor Activity by the Solubilization of COA-SPC."

Molecular Weight Estimation of t-Factor

The molecular weight range for the components contained in the Sephadex G-10 pool that contained t-Factor were estimated using a calibration curve plotted as the logarithm of molecular weight versus the ratio of $v_{e} / v_{o}$, a technique similar to the one employed by Marzullo (92). The calibration 
curve was produced by the elution of compounds of known molecular weights and different enough in molecular weight so they could be conveniently separated by the G-10 column. For this purpose, blue dextran (molecular weight $>200,000$ ), NADP (molecular weight 743), adenosine diphosphate (ADP; molecular weight 427), AMP (molecular weight 347), uridine (molecular weight 243), and nicotinamide (molecular weight 123) were chosen. All of these compounds, except blue dextran, were purchased from Sigma Chemical Company, st. Louis, Missouri.

The Sephadex G-10 was reequilibrated with several column volumes of $0.03 \mathrm{M} \mathrm{KCl}$. Each of the compounds for the calibration curve were dissolved to a concentration of $2 \mathrm{mg} / \mathrm{ml}$ in $0.03 \mathrm{M} \mathrm{KCl}$. Each compound was applied to the column individually and eluted to confirm the order at which they emerged from the column. The compounds were monitored at $260 \mathrm{m \mu}$ through a $1 \mathrm{~mm}$ flow cell; the peak of the elution pattern for the compounds was considered its $\mathrm{V}_{e} \cdot$ All the compounds were mixed, except blue dextran, at a concentration of $2 \mathrm{mg} / \mathrm{ml}$. The mixture was applied and eluted from the column. The elution volume of blue dextran was considered the void volume $\left(v_{o}\right)$ of the column and the ratio of the elution volume to the void volume $\left(\mathrm{v}_{\mathrm{e}} / \mathrm{v}_{\mathrm{o}}\right)$ for each compound was calculated relative to blue dextran. The relationship between molecular weight and $\mathrm{V}_{\mathrm{e}} / \mathrm{V}_{\mathrm{o}}$ was plotted on semi-logarithmic paper. The approximate molecular weight range of $t$-Factor was estimated by plotting the $\mathrm{v}_{\mathrm{e}} / \mathrm{v}_{\mathrm{o}}$ of the pool on the calibration curve. 
Treatment of t-Factor with Charcoal

The UM-05 filtrate was treated with charcoal to remove the $260 \mathrm{~m} \mu$ absorbing material. The procedure for the adsorption was essentially that of Bergkvist (93) and Persson (94). The charcoal pellets were six to fourteen mesh activated petroleum base obtained from Matheson, Coleman and Bell (Norwood, Ohio). Before use, the charcoal was washed several times on a funnel with each of the following solvents: 50 percent aqueous ethanol containing two percent concentrated ammonia hydroxide; $1 \mathrm{~N}$ hydrochloric acid; and deionized water. Following the rinse with water, the charcoal was suctioned dry and considered ready for use.

The ultraviolet absorption at $260 \mathrm{m \mu}$ in a $1 \mathrm{~cm}$ quartz cuvette was measured for the UM-05 filtrate using deionized water as the reagent blank. The UM-05 filtrate was combined with the charcoal in the ratio, $1 \mathrm{ml}$ filtrate to $1 \mathrm{~g}$ charcoal. The mixture was stirred for 30 minutes at $4^{\circ} \mathrm{C}$. Following the stirring period, the fluid was collected from the charcoal by suction filtration and was referred to as the "charcoal extract". The charcoal was resuspended several times in a total of $500 \mathrm{ml}$ of cold deionized water, and these washes were combined with the "charcoal extract". The "charcoal extract" and washes were concentrated by evaporation at $40^{\circ} \mathrm{C}$, so that concentration of the extract was close to the original applied to the charcoal. 
The charcoal extracted with water was suspended and eluted several times on a Buchner funnel with a total volume of $500 \mathrm{ml}$ of cold 25 percent aqueous ethanol containing 0.5 percent concentrated ammonium hydroxide. The "charcoal eluate" was evaporated at $40^{\circ} \mathrm{C}$ to dryness and redissolved in deionized water to approximately the original concentration of the applied UM-05 filtrate. The pH of the solution was adjusted to 5.8 with $I \mathrm{~N}$ hydrochloric acid, if necessary.

The ultraviolet absorption at $260 \mathrm{m \mu}$ of the "charcoal extract" and "charcoal eluate" were determined to assess the removal of nucleotide compounds by the charcoal adsorption procedure.

Assay. Both the "charcoal extract" and "charcoal eluate" were tested for activity as described under "Assay for t-Factor Activity by the Solubilization of COA-SPC."

Treatment of t-Factor with Ion-Exchange Resin

The large amino acid and peptide pool contained in the "charcoal extract" was subjected to batch ion-exchange chromatography (95). The "charcoal extract" was applied to Amberlite IR-120 cation exchange resin (Rohm \& Haas Comapny, Philadelphia, Pennsylvania) in the hydrogen $\left(\mathrm{H}^{+}\right)$form. The ratio $1 \mathrm{ml}$ "charcoal extract" to $3 \mathrm{~g}$ IR-120 was used.

The Amberlite IR-120 was washed several times on a Buchner funnel with deionized water followed by several washes with $1 \mathrm{~N}$ acetic acid. The $\mathrm{pH}$ of the "charcoal 
extract" was lowered to $\mathrm{pH} 3.1$ with glacial acetic acid. The pH adjusted "charcoal extract" and IR-120 resin were stirred together for a period of two hours at $4^{\circ} \mathrm{C}$. The "ion-exchange extract" was obtained by suction filtration followed by several washes of the ion-exchange resin with a total of $200 \mathrm{ml}$ of cold deionized water. The combined "ion-exchange extract" was concentrated by evaporation at $40^{\circ} \mathrm{C}$. The "ionexchange eluate" was formed by eluting the resin on a Buchner funnel with a total of $200 \mathrm{ml}$ of $1.5 \mathrm{~N}$ ammonium hydroxide. The "ion-exchange eluate" was concentrated by rotary evaporation and the $\mathrm{pH}$ adjusted to 5.8 with $1 \mathrm{~N}$ hydrochloric acid.

Assay. Both the "ion-exchange extract" and the "ionexchange eluate" were tested for $t$-Factor as described under "Assay for t-Factor Activity by the Solubilization of COASPC."

The Effect of Various Salts on the Recovery of COA-SPC

The following salts were tested for their ability to replace $\mathrm{KCl}$ for the enhancement of the solubilization of COASPC by t-Factor: sodium chloride ( $\mathrm{NaCl}$ ), magnesium chloride $\left(\mathrm{MgCl}_{2}\right)$, calcium chloride $\left(\mathrm{CaCl}_{2}\right)$, manganese chloride $\left(\mathrm{MnCl}_{2}\right)$, lithium chloride ( $\mathrm{LiCl})$, potassium acetate $\left(\mathrm{KC}_{2} \mathrm{H}_{3} \mathrm{O}_{2}\right)$, sodium acetate $\left(\mathrm{NaC}_{2} \mathrm{H}_{3} \mathrm{O}_{2}\right)$, potassium iodide (KI), sodium sulfate $\left(\mathrm{Na}_{2} \mathrm{SO}_{4}\right)$, potassium nitrate $\left(\mathrm{KNO}_{3}\right)$, and calcium phosphate $\left(\mathrm{Ca}_{2}\left(\mathrm{PO}_{4}\right)_{2}\right)$. All analytical reagents were purchased from J. T. Baker Chemical Company, Phillipsburg, New Jersey. 
The dichloride salts were dissolved in UM-05 filtrate containing $t$-Factor so that the chloride concentration was equivalent to the chloride concentration when $\mathrm{KCl}$ and $\mathrm{t}-$ Factor were mixed as described under "Assay for $t$-Factor Activity by the Solubilization of COA-SPC." The salts without a chloride anion were dissolved in t-Factor so that the concentration was $10 \mathrm{mg} / \mathrm{ml}$ of yeast suspension.

Controls were samples of yeast pellet material mixed with t-Factor but without salt addition, and pellet material mixed with salt and deionized water without t-Factor.

Assay. The t-Factor solutions with various salts and controls were tested as described under "Assay for $t$-Factor Activity by the Solubilization of COA-SPC."

\section{Estimation of Endogenous Chloride}

The mercurimetric method of Schales and Schales (96) was used for the estimation of chloride in UM-05 filtrate containing t-Factor. The method is a titration based on the ability to detect excess free mercuric ions after all the chloride ion is combined with the mercuric ion. The excess free mercuric ions are detected by the purple end-point color formed in the presence of diphenylcarbazone.

Reagents. $0.01 \mathrm{~N}$ mercuric nitrate (Mallinckrodt Chemical Company, st. Louis, Missouri) was prepared by dissolving 2.9 to $3.0 \mathrm{~g}$ of mercuric nitrate in a few hundred milliliters 
of deionized water with the addition of $20 \mathrm{ml}$ of $2 \mathrm{~N}$ nitric acid (J. T. Baker Chemical Company, Phillipsburg, New Jersey). The solution was made up with deionized water up to $1000 \mathrm{ml}$.

Diphenylcarbazone indicator (Eastman Kodak Company, Rochester, New York) was made by dissolving $0.4 \mathrm{~g}$ in $100 \mathrm{ml}$ of 95 percent ethyl alcohol.

The chloride standard was made by dissolving $584.5 \mathrm{mg}$ of sodium chloride in deionized water up to $1000 \mathrm{ml}$. This solution contained $0.355 \mathrm{mg}$ of chloride per milliliter.

Standardization of mercuric nitrate. Triplicate samples of $2 \mathrm{ml}$ aliquots of the chloride standard in $25 \mathrm{ml}$ Erlenmeyer flasks were titrated with the mercuric nitrate solution from a micro burette. Four drops of the indicator solution were added to each sample. Blank titrations were made by replacing the chloride standard with deionized water. The blank titration was subtracted from the milliliters of mercuric nitrate solution needed to titrate the chloride standard. The titrations were, averaged and the number of milligrams of chloride which react with $1.0 \mathrm{ml}$ of mercuric nitrate solution was calculated.

Sample titrations. Samples of the UM-05 filtrate were handled as the chloride standards above. Although the amber color of the filtrate obscurred the purple end-point, it could be detected. The number of milliliters of standardized 
mercuric nitrate solution needed to titrate a sample was used to calculate the milligrams per milliliter of chloride in a sample.

\section{Assessment of t-Factor Purity}

An estimation of the extent to which t-Factor was purified as compared to that in the crude supernatant, was based on the weight of total lyophilized solids contained in any particular fraction and on the extent it solubilized CoA-SPC.

\section{Testing Known Compounds for t-Factor Activity}

The compounds shown in Table $\mathrm{X}$, page 119 ("Results and Discussion"), were tested for their ability to be substituted for $t$-Factor by the method described under "Assay for $t$ Factor Activity by the Solubilization of COA-SPC." All components were the best analytical reagent available from sigma Chemical Company, st. Louis, Missouri.

Alternate Procedure for the Preparation of COA-SPC from Bakers' Yeast

Estimation of yeast cell volume. A weighed amount of fresh Bakers' yeast was suspended in a known volume of deionized water. The total volume of the yeast cells and water was noted. The difference between the total volume and the volume of water added was considered the approximate yeast cell volume. It was from this volume that dried yeast cell 
residues (to be described) were diluted for extraction of COA-SPC.

Drying the yeast cells. Thirty grams of fresh compressed Bakers' yeast was weighed into tared plastic petri dishes. The yeast was crumbled and spread evenly over the surface of the dishes. The yeast cells were placed at $4^{\circ} \mathrm{C}$, room temperature $\left(24^{\circ} \mathrm{C}\right)$, and in an oven at $50^{\circ} \mathrm{C}$. At 12-hour intervals, a plate at each temperature was removed and weighed to determine the percent of weight remaining. When the most appropriate drying period was determined, yeast cells were dried for that length of time for routine preparations and examination of other variables.

Rehydration of dried yeast cell residue. Dried yeast cell residues were ground with a porcelain mortar and pestle at $24^{\circ} \mathrm{C}$ to a particle size range of $38 \mu$ to $425 \mu$. Deionized water was added to dried, ground yeast cell residues to obtain the original wet weight before drying. Alternatively, water could be added to obtain the original yeast cell volume before drying. Potassium chloride was added to the smooth, uniformly suspended yeast residue at $10 \mathrm{mg} / \mathrm{ml}$ of yeast suspension. The water for rehydration was maintained at $4{ }^{\circ} \mathrm{C}$ except where noted.

Solubilization of COA-SPC. The rehydrated yeast cell residues and $\mathrm{KCl}$ mixtures were stirred for 18 hours at $4^{\circ} \mathrm{C}$. 
Alternative stirring temperatures were examined to see if the time for solubilization of COA-SPC could be shortened.

Assays of yeast cell extract. Following the 18-hour stirring step, the mixtures were centrifuged at 105,000 $\times \mathrm{g}$ for one hour at $4^{\circ} \mathrm{C}$. The supernatant liquid recovered was assayed for protein content as described under "Determination of Protein" and for COA-SPC activity as described under "Assay for COA-SPC Activity." 
CHAPTER IV

RESULTS AND DISCUSSION

Recovery of COA-SPC

Following the removal of the ether from the Bakers' yeast cells, a portion of the liquified yeast cell lysate was centrifuged to obtain the crude supernatant liquid (Materials and Methods, "Preparation of pellets containing COA-SPC"). This crude supernatant was assayed for COA-SPC activity by measuring the formation of $\left[{ }^{35} S\right]$-dephospho-COA-bound from the substrates ATP, D-pantothenic acid and $\left[{ }^{35} \mathrm{~S}\right]-\mathrm{L}$-cysteine. The crude supernatant fraction is shown in Table II as "stirring time, zero hours." Although this fraction contains protein which has been solubilized from the yeast cells, no COA-SPC activity was detected. However, as shown in Table II, COASPC activity gradually appeared after stirring the yeast cell lysate at $4^{\circ} \mathrm{C}$ in the presence of $10 \mathrm{mg} \mathrm{KCl}$ per milliliter of yeast lysate. This concentration of $\mathrm{KCl}$ was chosen because the storage properties of COA-SPC were shown to be better at this concentration than at other $\mathrm{KCl}$ concentrations $(63,64$, 68). At three-hour intervals during the stirring procedure, 10-ml samples of the crude yeast cell lysate were removed from the stirring vessel and centrifuged to obtain the crude 
TABLE II

COA-SPC ACTIVITY OF THE YEAST CELL LYSATE ${ }^{a}$

\begin{tabular}{cccc}
\hline \hline $\begin{array}{c}\text { Stirring } \\
\text { Time }\end{array}$ & $\begin{array}{c}\text { CoA-SPC } \\
\text { Activity }\end{array}$ & $\begin{array}{c}\text { Soluble } \\
\text { Protein }\end{array}$ & $\begin{array}{c}\text { Specific } \\
\text { Activity }\end{array}$ \\
\hline$\frac{\text { (hours) }}{0}$ & $\frac{\text { (nmoles) }}{(\mathrm{mg} / \mathrm{ml})}$ & $\frac{(\text { nmoles } / \mathrm{mg} / \mathrm{h})}{25}$ & 0 \\
3 & 0 & 26 & 0 \\
6 & 0 & 29 & 5.6 \\
9 & 8.1 & 46 & 5.8 \\
12 & 14.4 & 96 & 6.3 \\
15 & 30.3 & 118 & 6.3 \\
18 & 36.9 & 120 & 6.3 \\
\hline \hline
\end{tabular}

$a_{A t}$ each stirring time indicated, a sample of the crude homogenate was removed, centrifuged at $105,000 \mathrm{x} g$ for one hour at $4^{\circ} \mathrm{C}$. The crude extract was assayed for COA-SPC as described under "Assay for COA-SPC Activity," and for protein as described under "Determination of Protein." Activity and specific activity calculations are described under "Assay for COA-SPC ACtivity." 0 indicates no activity. 
extract for assay of soluble protein content and COA-SPC. Although it was observed that stirring was not an absolute requirement for the recovery of COA-SPC activity, since simply allowing the crude yeast cell lysate to stand in the cold or by bubbling nitrogen or air through the lysate proved to be almost as effective, the practice of stirring was followed. Table II shows that COA-SPC activity was first detected in the six-hour crude extract. Once activity was detected, a progressive increase in activity was observed during the ensuing 18 hours of stirring. Although not shown in Table II, some COA-SPC preparations using other sources of commercial yeast required additional stirring time for maximum activity of COA-SPC, but most preparations showed a progressive decrease in COA-SPC activity after 18 hours. The 18-hour stirring time has resulted in the optimum level of COA-SPC activity for most preparations and has been adopted as the time to indicate the optimal level of COA-SPC activity from pellet preparations.

The gradual recovery of COA-SPC seems to suggest the enzyme complex is trapped or attached in some manner in the insoluble portion of the yeast cell lysate. There also appears to be a requirement for the ether treatment, because simply freezing and thawing fresh Bakers' yeast alone or in buffer fail to yield COA-SPC. Likewise, substitution of other organic solvents give little or no CoA-SPC activity. 
The requirement for ether therefore, may suggest some alteration of the yeast cell membrane which allows the enzyme access to the liquid portion of the cell.

\section{Discovery of the Yeast Component t-Factor}

Taking advantage of the observation that COA-SPC appeared to remain within the insoluble fractions of the yeast cell lysate prior to stirring, it was hypothesized that a simple purification of COA-SPC could be obtained. The approach was simply to separate, by centrifugation, the insoluble portion of the yeast cell lysate from the soluble portion (crude supernatant liquid). Discarding the crude supernatant liquid to remove proteins and other soluble components of the yeast cell, followed by washing the pellet material to remove loosely bound cellular components, the pellet material could then be resuspended in buffer to be stirred for 18 hours. This process, however, did not yield active COA-SPC.

The process was reexamined, speculating that a natural component of the yeast cell lysate may be involved in the solubilization of COA-SPC. Another possibility was that COASPC may be in the soluble fraction of the yeast cell lysate in an inactive form. Figure 7 shows a diagrammatic summary of the procedures involved, and Table III presents evidence that a yeast component is required for the solubilization of COASPC. 


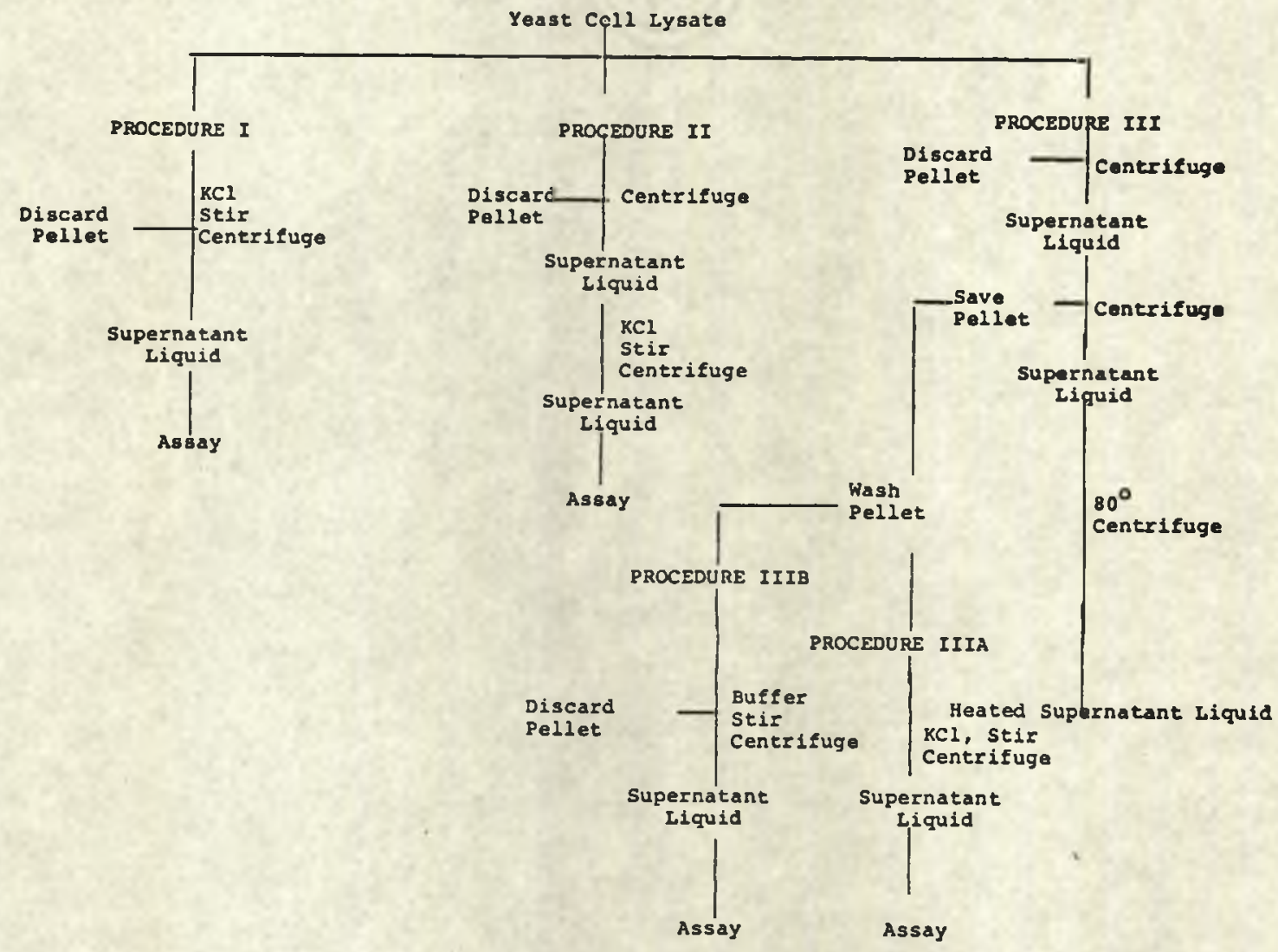

Figure 7. Diagrammatic summary of the procedures for the preparation of COA-SPC and involvement of a cellular component for its recovery. 
TABLE III

YEAST CELL COMPONENT ESSENTIAL FOR THE SOLUBILIZATION OF COA-SPC

\begin{tabular}{lccc}
\hline \hline Procedure $^{a}$ & CoA-SPC Activity $^{b}$ & $\begin{array}{c}\text { Soluble } \\
\text { Protein }\end{array}$ & $\begin{array}{c}\text { Specific } \\
\text { Activity }\end{array}$ \\
\hline$\underline{\text { (nmoles) }}$ & $\underline{(\mathrm{mg} / \mathrm{ml})}$ & $\underline{(\text { nmoles } / \mathrm{mg} / \mathrm{h})}$ \\
I & 18.8 & 60 & 6.2 \\
II & .7 & 26 & 0.6 \\
IIIA & 17.9 & 40 & 8.9 \\
IIIB & 0.4 & 10 & 0.8 \\
IIIC & 16.8 & 30 & 11.2 \\
\hline \hline
\end{tabular}

${ }^{a}$ See Figure 7, "Results and Discussion."

beasured and calculated according to "Assay for CoA-SPC Activity." 
The yeast cell lysate in Figure 7 was produced by exposure of Bakers' yeast to ether and dry ice as described under "Preparation of pellets containing COA-SPC," and the liquified cell lysate was divided into three equal parts. One portion of the lysate, procedure I, was stirred in the presence of $\mathrm{KCl}$ for 18 hours. The supernatant liquid produced by the $105,000 \times \mathrm{g}$ centrifugation step was tested and found to contain COA-SPC activity, as shown in Table III. The second portion of the lysate was treated according to procedure II, Figure 7. The crude yeast cell lysate was initially centrifuged at $105,000 \times \mathrm{g}$ and the pellet material discarded. The crude supernatant then had $\mathrm{KCl}$ added in a concentration equivalent to $10 \mathrm{mg} / \mathrm{ml}$ of yeast cell lysate. The mixture was stirred for 18 hours and tested for COA-SPC activity. As shown in Table III, procedure II was essentially void of CoASPC activity. This confirmed that COA-SPC was associated with the insoluble portion of the lysate and also supported the fact that COA-SPC was not made by catalytic conversion of the proenzyme form to the active enzyme form.

The third portion of the crude yeast cell lysate, procedure III, was centrifuged at $1,000 \times \mathrm{g}$ for 10 minutes to $\mathrm{rid}$ the lysate of whole cells and starch added during the processing of commercial compressed Bakers' yeast. The $1,000 \mathrm{x}$ g pellet material was discarded and the remainder of the suspended lysate was centrifuged at $105,000 \times \mathrm{g}$ for one hour. 
The pellet material and crude supernatant liquid were separated and saved. The pellet material was washed two times as described under "Preparation of pellets containing COA-SPC." The crude supernatant was heat treated as described under "Preparation of t-Factor."

In procedure IIIA, Figure 7, page 92, heat treated supernatant liquid was combined with washed pellet material. Potassium chloride was added and the mixture was stirred for 18 hours. The supernatant liquid recovered by centrifugation as shown in Table III, page 93, contained active COA-SPC. This was very significant since procedure III B was void of COA-SPC activity. Procedure III B was performed by stirring for 18 hours washed pellet material suspended in $0.05 \mathrm{M}$ sodium acetate, $\mathrm{pH} 5.8$ and $\mathrm{KCl}$. The $\mathrm{pH} 5.8$ was chosen since the crude supernatant and heat treat supernatant liquids had $\mathrm{pH}$ values close to 5.8. In procedure III $\mathrm{C}$, not shown in Figure 7, page 92, heat treated supernatant liquid and $\mathrm{KCl}$ were mixed for an additional 18 hours with the pellet material recovered from procedure III B. The supernatant liquid recovered from procedure III C contained active COA-SPC.

The information presented thus far contains two vitally important characteristics of COA-SPC: (I) COA-SPC appears to be bound to or trapped in an extremely heavy, insoluble yeast cell component(s), and will remain in that state unless conditions described under procedure I, procedure III $A$ and procedure III $C$ are followed; and (2) a soluble component(s) of 
the yeast cell is essential for the release or solubilization of COA-SPC. Because the component(s) is yet to be identified, it will be referred to as t-Factor, named for the author. t-Factor does not appear simply to be the autolytic enzyme system that digests the complex polysaccharide wall of the yeast cell and thus allows the release of COA-SPC. It has been reported that the autolytic enzymes are completely inactivated by heating at $60^{\circ} \mathrm{C}$ for 10 minutes (97). The fact that the autolytic enzyme system could play a role in the solubilization of COA-SPC is not discounted. There exist cases where organic solvents, such as ether, induce autolysis (98). Solvent induced autolysis may activate phospholipases and cause disorganization of membrane structure. In the case of COA-SPC solubilization, the ether may render the location of COA-SPC in the yeast cell accessible to t-Factor. Although other proteinacous materials are solubilized by the stirring process, t-Factor appears to be rather specific for the solubilization of COA-SPC. For instance, protein was solubilized in procedure III B, Table III, page 93, by buffer and $\mathrm{KCl}$, but the buffer and $\mathrm{KCl}$ did not solubilize COA-SPC until t-Factor was added, procedure IIIC, Table III, page 93. Since the identity of t-Factor is unknown, its presence in a particular fraction of yeast cell supernatant liquid can be detected only by indirect assay; that is, assaying for activity of COA-SPC solubilized by t-Factor. The unique role 
t-Factor plays in the yeast cell made it essential to understand further characteristics of the component.

\section{Alternate Methods for the Isolation of t-Factor}

Since the data in Table III, page 93, appeared to suggest that the components of $t-F a c t o r$ may be heat stable and easily extracted from the yeast cell, an alternate procedure for the extraction of t-Factor was attempted (see "Alternate Method for the Preparation of t-Factor"). Freezing and thawing of fresh Bakers' yeast with liquid nitrogen rendered a liquified suspension similar to the crude yeast cell lysate produced by the ether-dry ice method of preparation. It was apparent that some cellular damage had been accomplished by this technique based on the protein, and $280 \mathrm{m \mu}$ and $260 \mathrm{m \mu}$ absorbing material in the crude supernatant fraction. However, when the liquified suspension produced by the liquid nitrogen freeze-thaw procedure was stirred in the presence of $\mathrm{KCl}$ for 18 hours, no COA-SPC activity could be detected. When the crude supernatant liquid of the liquid nitrogen procedure was combined with pellet material (see "Preparation of pellets containing COA-SPC") from the ether-dry ice procedure and stirred in the presence of $\mathrm{KCl}$ for 18 hours, COA-SPC was solubilized. It was judged at this time that the ether treatment was necessary for COA-SPC to be solubilized by $t-$ Factor and that $t$-Factor was recovered from the yeast cell by the liquid nitrogen procedure. 
Although the freeze-thaw method provided by the liquid nitrogen treatment was unsuccessful in terms of producing COA-SPC pellets, it did however allow for a more time efficient method for the production and study of $t$-Factor. Since evidence exists that t-Factor was contained in the heat treated supernatant liquid of crude yeast cell lysates and because of this heat treatment was probably not an autolytic enzyme (97), methods were designed to isolate a pool of tFactor material. Figure 8 shows a diagrammatic summary of the techniques used to isolate a pool containing t-Factor.

As shown in Table IV, when heat treated supernatant was dialysed according to "Filtration of the t-Factor through Dialysis Tubing," the t-Factor activity was shown to be present in the material that passed through the membrane. Likewise, when heat treated supernatant was filtered according to "Cone filtration of t-Factor," the COA-SPC solubilizing activity was evident in the filtrate. Since the No. 8 dialyzing tubing employed in the experiment was supposed to retain molecules greater than 20,000 molecular weight, a molecular weight of less than 20,000 was suggested for tFactor. However, since vacuum dialysis was employed, the stretching of the membrane pores could have allowed molecules greater than 20000 molecular weight to pass into the dialysate. The activity present in the cone filtrate, however, also supported a molecular weight for $t$-Factor of less than 25:000. It would have been expected that t-Factor would 


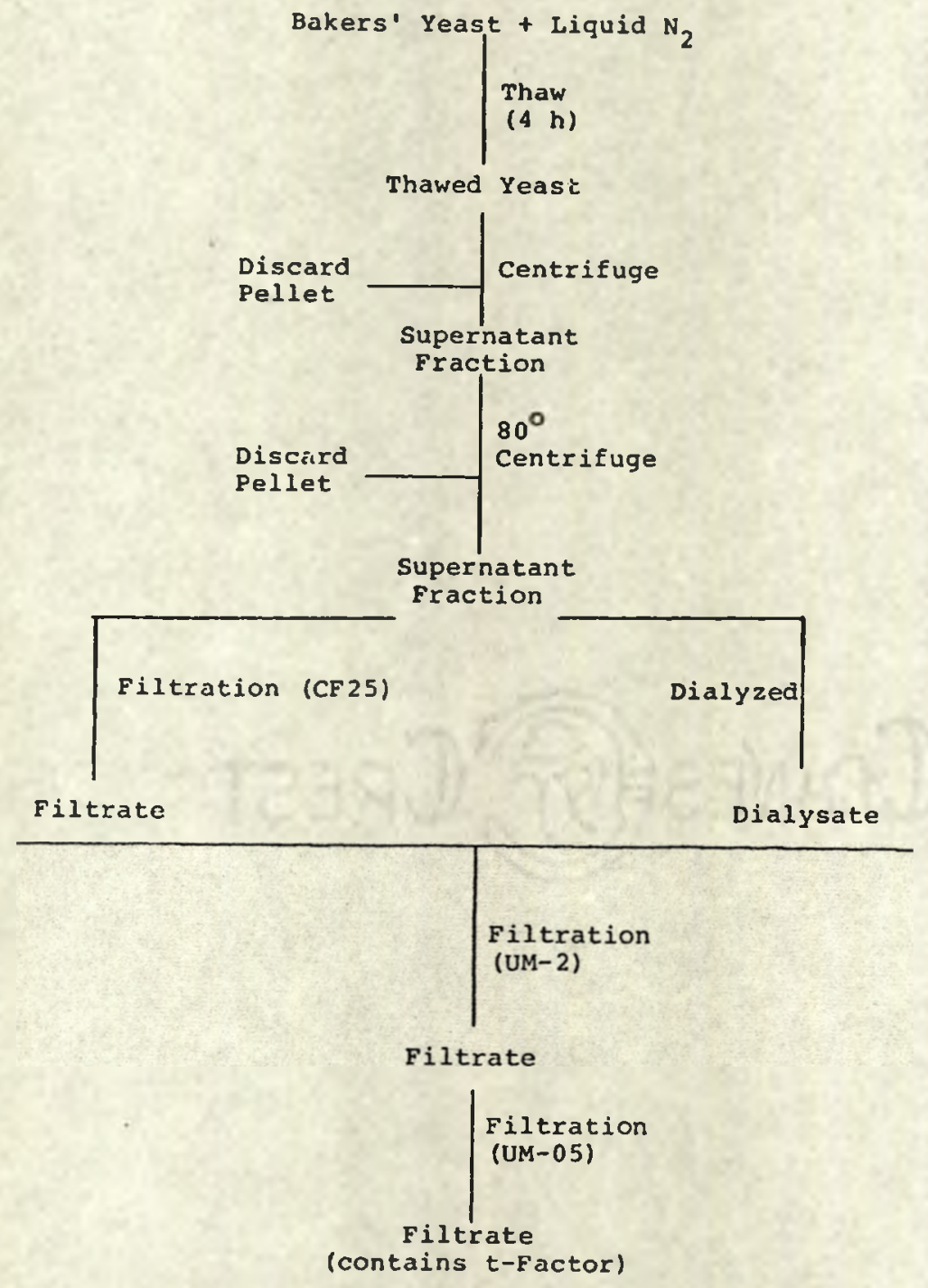

Figure 8. Diagrammatic summary of the procedures for the isolation of $t$-Factor. 
TABLE IV

SOLUBILIZATION OF COA-SPC WITH VARIOUS SUBFRACTIONS

OF THE CRUDE SUPERNATANT

\begin{tabular}{ll}
\hline \hline Fraction & \\
& $\begin{array}{c}\text { CoA-SPC } \\
\text { Activity }\end{array}$ \\
\hline Heat Treated Supernatant & (nmoles) \\
Dialysate & 17.9 \\
Cone Filtrate & 17.0 \\
UM-2 Filtrate & 17.2 \\
UM-05 Filtrate & 16.0 \\
\hline \hline
\end{tabular}

asee Figure 8, "Results and Discussion." COA-SPC was solubilized by mixing the sub-fraction and $\mathrm{KCl}$ with pellet material prepared as described under "Preparation of pellets containing COA-SPC." The mixture was stirred at $4{ }^{\circ} \mathrm{C}$ for 18 hours.

beasured and calculated according to "Assay for COA-SPC Activity." 
remain with the components retained by the cone or retained following dialysis if it were a protein, such as a heat stable proteolytic enzyme, with a specificity for the solubilization of COA-SPC.

In a related study (data not shown), it was found that if crude supernatant liquid was substituted for heat treated supernatant liquid and subjected to dialysis and filtration, the resulting filtrate and dialysate showed a decreased solubilization of COA-SPC. It was therefore speculated that endogenous enzymes with the ability to destroy t-Factor may be contained in the crude supernatant liquid and as the liquid was concentrated by dialysis and filtration, the enzyme action on t-Factor was enhanced. Alternatively, it was speculated that as the macromolecules were concentrated within the bag or cone, t-Factor may bind and not be allowed to pass through the membranes. In order to determine which speculation was correct, studies were designed in which the crude supernatant liquid was incubated at $36^{\circ} \mathrm{C}$ for two and four hours followed by heat treatment. However, this resulting supernatant liquid had t-Factor activity. Therefore, this study did not support either of the above speculations. The dialysate or filtrate containing t-Factor was ultrafiltered through an Amicon UM-2 filter. Table IV shows tFactor activity was expressed in the filtrate, thus suggesting a molecular weight for t-Factor of less than 1,000. Furthermore, when the UM-2 filtrate was passed through the 
UM-05 filter, the t-Factor activity also was contained in that filtrate. This suggested a molecular weight of less than 500 for $t-F a c t o r$. It became obvious at this time that $t-$ Factor was not a macromolecule but appeared to be a heat stable, low molecular weight component; a description used frequently to describe cofactors and vitamins. The UM-05 ultrafilter was tested for its retainability of COA (molecular weight 767) and angiotensin II (molecular weight 1026). Coenzyme $A$ appeared to be freely filterable, but angiotensin II was not. It was apparent that the UM-05 filter was not completely reliable to prevent the passage of compounds greater than 500 molecular weight. Therefore, a reasonable estimate for the upper limit of the molecular weight range of t-Factor was 1,000 .

Effect of Heat on t-Factor

The apparent non-lability of t-Factor demonstrated by its presence in the heat treated supernatant was more rigorously examined. Table $V$ shows that heating t-Factor contained in the UM-05 filtrate at $80^{\circ} \mathrm{C}$, an additional 24 hours beyond the initial heat treatment, resulted in little or no loss of $t$-Factor activity. As shown in Table $v$, the apparent decrease in t-Factor activity was approximately 10 percent based on solubilized COA-SPC activity. This may represent inherent characteristics of the recovery procedure for $t$ Factor because in a similar experiment carried out at $100^{\circ} \mathrm{C}$, parallel results were obtained. 


\section{TABLE V}

THE EFFECT OF HEAT ON $t$-FACTOR ACTIVITY *

\begin{tabular}{cc}
\hline $\begin{array}{c}\text { Time } \\
\text { (hours) }\end{array}$ & $\frac{\text { CoA-SPC Activity }}{\text { (nmoles) }}$ \\
\hline 0 & 20.6 \\
0.5 & 19.4 \\
1 & 19.8 \\
3 & 19.1 \\
5 & 19.0 \\
24 & 18.7 \\
\hline
\end{tabular}

${ }^{*} t$-Factor in the UM-05 filtrate was heated at $80^{\circ} \mathrm{C}$ for the period of time indicated. Following the heating procedure, t-Factor was added to pellet material obtained by centrifugation of the crude yeast cell lysate and stirred as described under "Assay for t-Factor Activity by the Solubilization of COA-SPC."

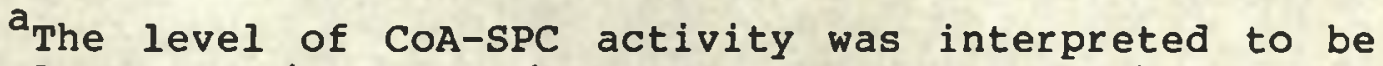
directly proportional to the amount of $t$-Factor stirred with the insoluble pellet material. COA-SPC activity was determined as described under "Assay for COA-SPC Activity." 
The UM-05 filtrate was also treated according to the methods outlined under "Ashing of t-Factor." when the amber solution of UM-05 filtrate was evaporated to dryness and charred, heavy black smoke evolved. After ashing at $800^{\circ} \mathrm{C}$ for two hours, the white powder that remained was tested for t-Factor activity. Since oxides are formed upon ashing, part of the ashed material was insoluble in water. The soluble portion of the ashed material was tested for $t$-Factor activity as described under "Assay for t-Factor Activity by the Solubilization of COA-SPC." Another portion of the ash was dissolved in hydrochloric acid to solubilize oxides of compounds formed. Even in the acid solution, a small amount of the material was insoluble. The acid ash was neutralized to pH 5.8 and tested for t-Factor activity. Although protein material was solubilized from pellet material, no COA-SPC activity was evident. The information provided by ashing the UM-05 filtrate would appear to suggest that $t$-Factor is not an inorganic compound such as salt or metal cofactor. Although t-Factor activity could have been lost during the evaporation procedure or could still be present in the small amount of residue not soluble after ashing, the evidence suggests $t$-Factor is probably organic in nature.

Concentration of t-Factor on the Solubilization of COA-SPC

A relationship between the solubilization of COA-SPC and the amount of t-Factor present was studied. The UM-05 
filtrate employed in this experiment was prepared from a crude supernatant of cell lysate that appeared to give optimal COA-SPC activity after 18 hours stirring (see Table II, page 89). Since the composition of $t$-Factor is unknown and at this time cannot be quantitated, dilutions were made with water of the $t$-Factor contained in the UM-05 filtrate. It is shown in Table VI that as the t-Factor solution was diluted, the level of COA-SPC activity decreased proportionally. In its most diluted form, the $t$-Factor preparation does not solubilize COA-SPC but other proteins continue to be solubilized. The extraneous proteins solubilized were due to the presence of $\mathrm{KCl}$ added when $t$-Factor activity was assayed. since decreasing the concentration of $t$-Factor resulted in a proportional decrease in the solubilization of COA-SPC it seemed logical that increasing the concentration of $t$-Factor above that which was initially present in the yeast cell might increase the amount of COA-SPC solubilized. These studies were repeated using the "charcoal extract" as a source of $t$-Factor (see Table XII, page 127). Although $t-$ Factor in the "charcoal extract" was purified to a greater extent than in the UM-05 filtrate, a similar pattern of COASPC solubilization was obtained related to t-Factor concentration.

Many other low molecular weight components of the yeast cell are contained in the UM-05 filtrate. Some of these components (i.e., COA) are inhibitors of COA-SPC activity. 
TABLE VI

EFFECT OF THE CONCENTRATION OF T-FACTOR

ON THE SOLUBILIZATION OF COA-SPC

\begin{tabular}{lccc}
\hline $\begin{array}{l}\text { Concentration of } \\
\text { t-Factor Relative } \\
\text { to Original }\end{array}$ & $\begin{array}{c}\text { CoA-SPC } \\
\text { Activity }\end{array}$ & $\begin{array}{l}\text { Soluble } \\
\text { Protein }\end{array}$ & $\begin{array}{c}\text { Specific } \\
\text { Activity }\end{array}$ \\
\hline & $\underline{\text { (nmoles) }}$ & $\underline{\text { (mg/ml) }}$ & (nmoles $/ \mathrm{mg} / \mathrm{h})$ \\
2.00 & 28.2 & 21.0 & 26.9 \\
1.00 & 29.6 & 15.0 & 39.5 \\
0.75 & 21.0 & 13.5 & 31.3 \\
0.50 & 15.2 & 12.0 & 25.3 \\
0.20 & 5.7 & 11.4 & 10.0 \\
0.10 & 0.0 & 10 & 0.0 \\
\hline \hline
\end{tabular}

a UM-05 filtrate obtained from crude supernatant with apparent maximal COA-SPC solubilizing activity as diluted with deionized water. The 1.00 refers to the original concentration and the decimal fractions to the dilution; the quantity 2.00 refers to the twice concentrated UM-05 filtrate. Each sample was assayed for $t$-Factor activity as described in "Materials and Methods, Assay for t-Factor Activity by the Solubilization of COA-SPC." 
Thus, when the UM-05 filtrate containing t-Factor is concentrated, any inhibitors present are also concentrated, therefore the inability to detect increased solubilization of additional COA-SPC by adding higher concentrations of $t-$ Factor could be due to an increased concentration of inhibitors on COA-SPC activity. Although the "charcoal extract" is more purified than the UM-05 filtrate, cellular components other than t-Factor are present. Consequently, inhibition of COA-SPC activity may still be present in this extract.

\section{Action of Proteolytic Enzymes on t-Factor}

The data in Table VII shows that t-Factor is not digested by either trypsin or protease. Although it was apparent by the filterability of t-Factor through the UM-05 that $t-$ Factor was not a protein-like molecule, the possiblity did exist that t-Factor could be a peptide. It could be argued that the large pool of low molecular weight compounds could contain other peptides competing with t-Factor for the action by the proteolytic enzymes; but since there was not an indication of any decrease in t-Factor activity, it was concluded that t-Factor was not susceptible to attack by these proteases. Therefore, t-Factor apparently contained no peptide bonds (protease), or arginine or lysine residues (trypsin).

\section{Preparative Paper Chromatography}

When UM-05 filtrates containing t-Factor activity were chromatogramed in Solvent I (see "Paper Chromatography"), 
TABLE VII

EFFECT OF PROTEOLYTIC ENZYMES ON $t$-FACTOR

\begin{tabular}{lc}
\hline Treatment $^{a}$ & $\begin{array}{c}\text { CoA-SPC } \\
\text { Activity }\end{array}$ \\
\hline & $\frac{\text { (nmoles) }}{}$ \\
Trypsin & 20.6 \\
Trypsin Control & 20.4 \\
Protease & 20.6 \\
Protease Control & 20.5 \\
\hline \hline
\end{tabular}

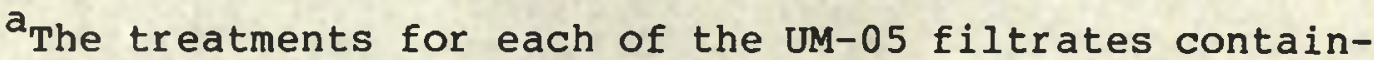
ing $t-F a c t o r$ was described under "Proteolytic Treatment of $t$ Factor." Controls were incubated with proteolytic enzymes that were first inactivated by boiling. Following the digestion incubations, treated $t$-Factor solutions were recovered for testing by vacuum dialysis.

$b_{\text {The solutions recovered by vacuum dialysis were tested }}$ for $t$-Factor activity as described under "Assay for $t$-Factor Activity by the Solubilization of COA-SPC." 
ninhydrin positive material was spread from the origin to the solvent front in at least thirteen overlapping spots. The chromatograms were cut into four segments as shown in Figure 9; segment $1 \mathrm{R}_{\mathrm{f}}=.000$ to .075 , segment $2=.075$ to .410 , segment $3 \mathrm{R}_{\mathrm{f}}=.410$ to .765 , and segment $4 \mathrm{R}_{\mathrm{f}}=.765$ to 1.00 . The t-Factor was localized in segment 1 of the chromatogram run in Solvent I. Although paper chromatography resulted in further purification of t-Factor, the material in segment 1 showed heterogeneity based upon ninhydrin positive, ultraviolet absorbing, organophosphate compounds and sulfhydryl compounds. The abundance of organic phosphate and ultraviolet absorbing material could be attributed to adenine nucleotide compounds that are easily extracted from yeast and from the observation that COA, ATP, AMP, ADP, and cyclic AMP all stayed within the $R_{f}$ zone 0.075 when chromatographed in Solvent I. Rechromatography of the extract from segment 1 in Solvent II further separated ultraviolet absorbing and ninhydrin staining compounds. In this solvent system, t-Factor also remained in segment $I\left(R_{f}=.000\right.$ to 0.361$)$ (Table VIII).

\section{Elution Pattern of t-Factor on Sephadex G-10}

The equivalent of $10 \mathrm{ml}$ of UM-05 filtrate containing tFactor was passed through a Sephadex G-10 column as described under "Permeation Chromatography of t-Factor on Sephadex G10." The typical elution pattern as monitored at $260 \mathrm{~m} \mu$ with water as the eluent is shown in Figure 10. Although it is not 


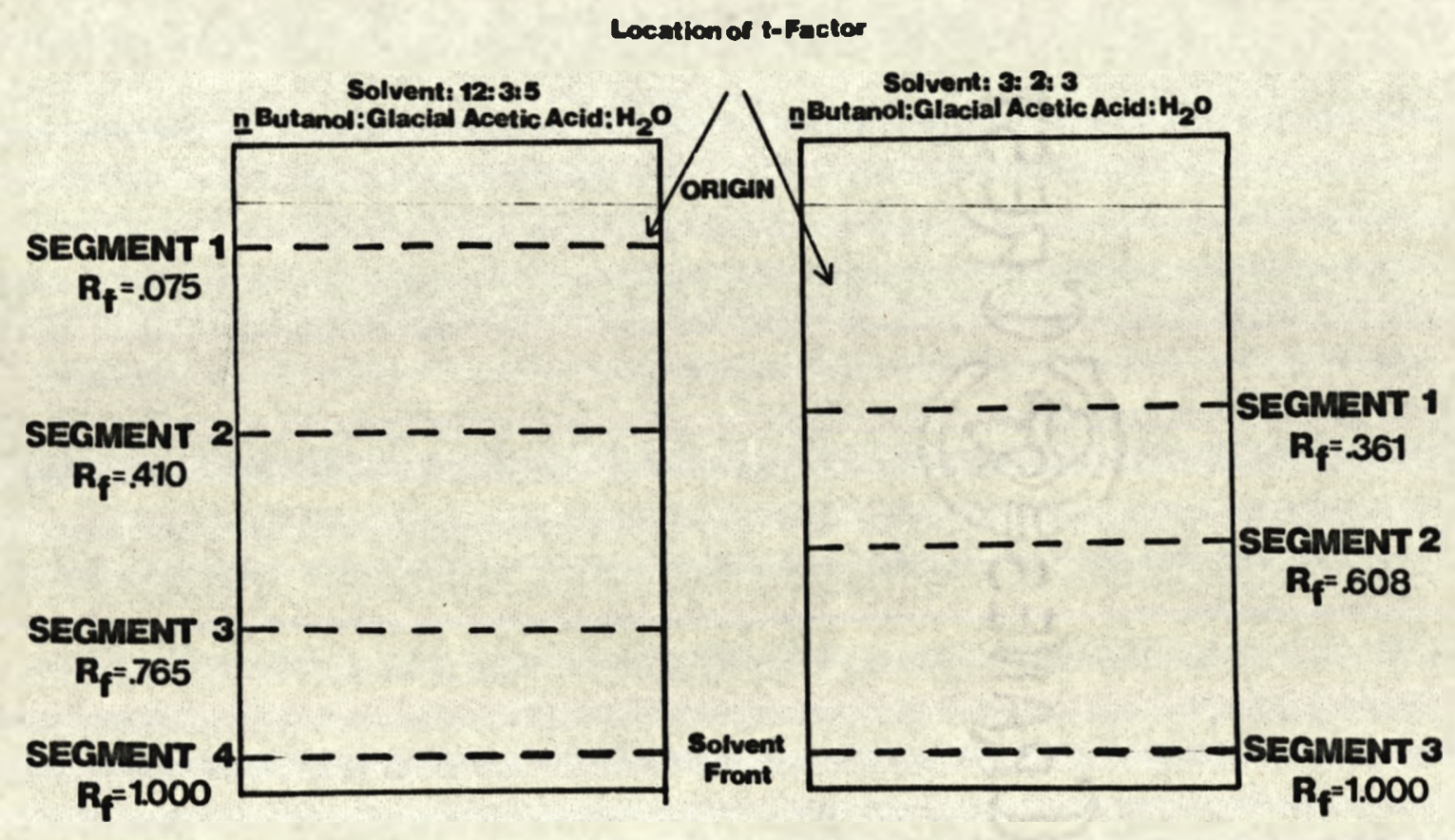

Figure 9. The location of t-Factor after paper chromatography. 
TABLE VIII

\section{PREPARATIVE PAPER CHROMATOGRAPHY OF $t$-FACTOR}

\begin{tabular}{ccc}
\hline Segments $^{a}$ & $\frac{\text { COA-SPC Activity }}{\text { (nmoles) }^{\mathrm{b}}}$ \\
\hline 1 & $\mathrm{I}^{\text {Solvent }}$ II \\
2 & 22.0 & 21.0 \\
3 & 0 & 0 \\
4 & 0 & 0 \\
\hline \hline
\end{tabular}

asee Figure 9 and "Paper Chromatography" for details of segmentation.

$b_{\text {Extracts from the paper chromatogram were handled as }}$ described under "Paper Chromatography" and tested for tFactor activity as described under "Assay for t-FActor Activity by the Solubilization of COA SPC." 


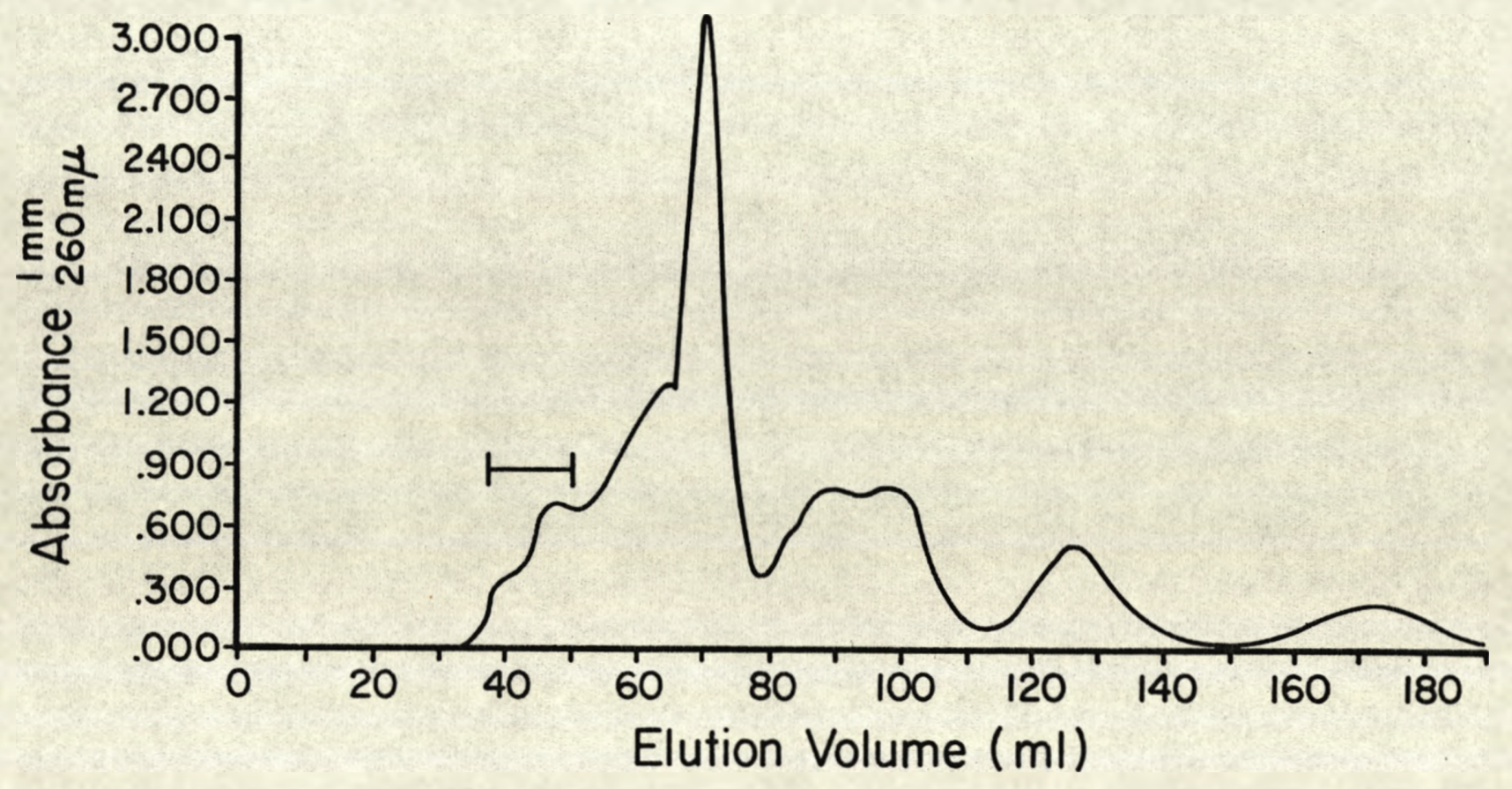

Figure 10. The Sephadex G-10 elution pattern of the Amicon UM-05 filtrate fraction containing t-Factor. 
known whether t-Factor absorbs ultraviolet light at $260 \mathrm{m \mu}$, other components of the UM-05 filtrate do. To determine the portion of the elution volume that contained t-Factor activity, fractions were pooled, lyophilized and tested for activity as described under "Assay for t-Factor Activity by the Solubilization of COA-SPC."

The t-Factor active material was eluted in the fraction volume $39.6 \mathrm{ml}$ to $51.7 \mathrm{ml}$ shown as the bracket in Figure 10 . The pattern of $260 \mathrm{~m}_{\mu}$ absorbing components of the UM-05 filtrate suggests that some of the components may have an affinity for the column matrix. The suggestion arises from the fact that the last two eluting peaks require an elution volume larger than the total column volume $(1.08 \mathrm{ml})$. In an effort to minimize these effects, the UM-05 filtrate was eluted with $0.03 \mathrm{M} \mathrm{KCl}$, however, no difference in the elution pattern of $t$-Factor or $260 \mathrm{m \mu}$ absorbing compounds were noted. Therefore, it was decided to use water as the eluent routinely.

Paper chromatography of the t-Factor active fraction contained contaminating components that absorbed ultraviolet light, were ninhydrin positive, and contained organic phosphates. Column chromatography of t-Factor purified by paper chromatography failed to resolve t-Factor from many of these contaminating components (see "Paper Chromatography"). 
Molecular Weight Estimation of t-Factor

A mixture of compounds with strong ultraviolet absorption at $260 \mathrm{~m}$ and of known molecular weights were chromatographed on the Sephadex G-10 column to obtain a calibration curve. In Figure 11, the calibration curve is plotted according to the method of Marzullo et al. (92). The molecular weight assigned to t-Factor based on its elution pattern on Sephadex G-10 is approximately 400 to 550 (see Figure 10, page 112). However, since compounds as large as 1,000 molecular weight could be contained in the UM-05 filtrate, and since t-Factor activity begins to appear close to the void volume of the column, a more liberal molecular weight estimate may be 400 to 1,000 .

Requirement for $\mathrm{KCl}$ or Chloride Ion

Solubilization of COA-SPC by $t$-Factor is enhanced when $\mathrm{KCl}$ is added to the mixture (Table IX). Because of the presence of endogenous chloride ion (average $0.92 \mathrm{mg} / \mathrm{ml}$ ) in the UM-05 filtrate containing t-Factor, some COA-SPC activity was detected without the addition of exogenous $\mathrm{KCl}$ to the stirring flask. However, $\mathrm{KCl}$ in $\mathrm{H}_{2} \mathrm{O}$ or in $0.05 \mathrm{M}$ Trisacetate, $\mathrm{pH} 7.2$, in the absence of $t$-Factor did not release COA-SPC from yeast pellet material. Although t-Factor is required and may be specific for the release of COA-SPC, the amount of protein present in the supernatant fraction following the stirring of pellet material with t-Factor and $\mathrm{KCl}$ is 


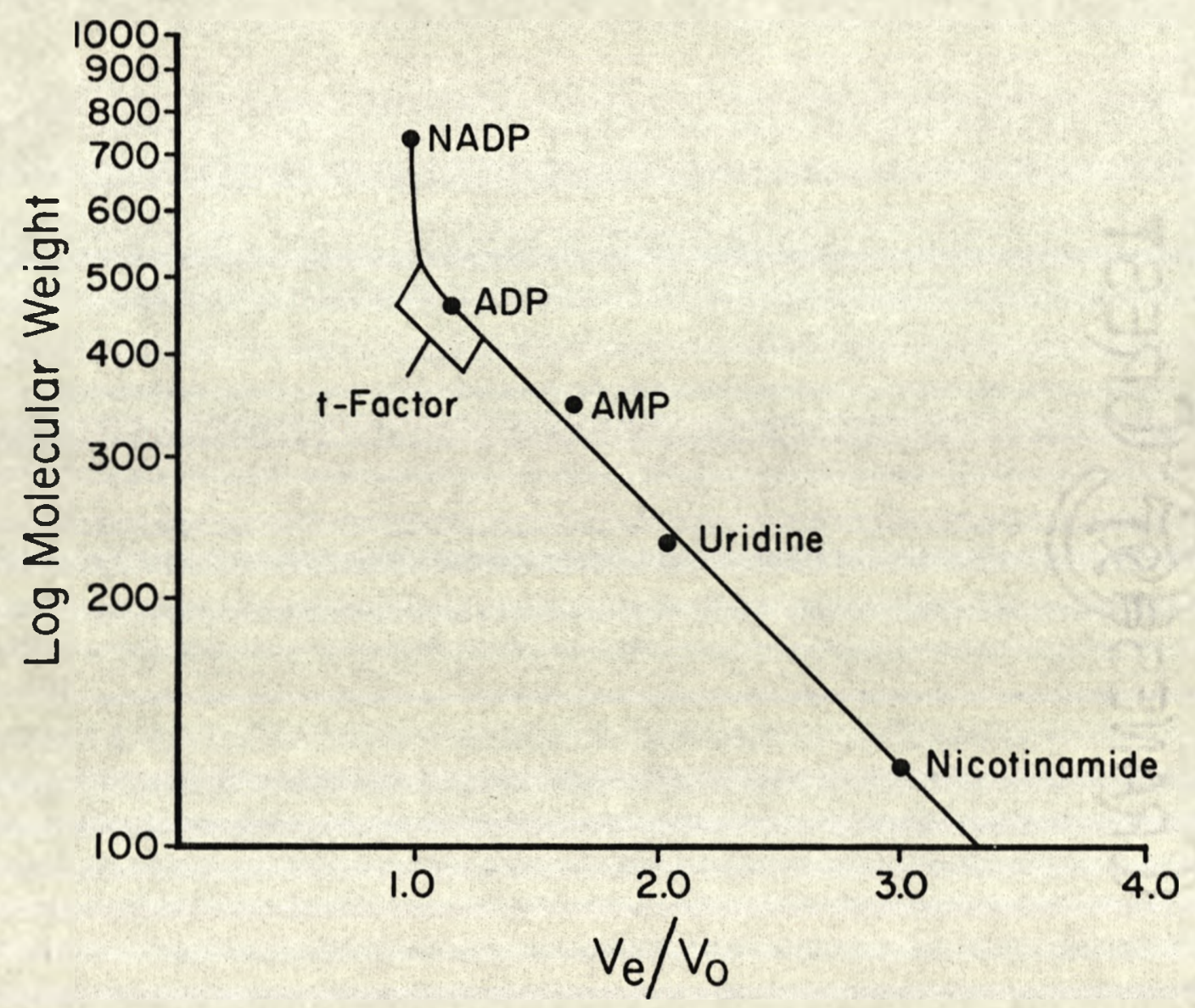

Figure 11. The sephadex G-10 calibration curve for the estimation of the molecular weight of t-Factor. 
TABLE IX

EFFECT OF VARIOUS SALTS ON THE SOLUBILIZATION OF COA-SPC

\begin{tabular}{|c|c|c|}
\hline \multicolumn{2}{|c|}{ Components Added ${ }^{\mathrm{a}}$} & \multirow{2}{*}{$\frac{\text { CoA-SPC Activity }}{\text { (nmoles) }}$} \\
\hline t-Factor & Salt & \\
\hline+ & - & 5.2 \\
\hline+ & $\mathrm{KCl}$ & 19.8 \\
\hline - & $\mathrm{KCl}^{\mathrm{b}}$ & 0.5 \\
\hline+ & $\mathrm{NaCl}$ & 18.2 \\
\hline+ & $\mathrm{MgCl}_{2}$ & 19.3 \\
\hline+ & $\mathrm{CaCl}_{2}$ & 25.0 \\
\hline+ & $\mathrm{MnCl}_{2}$ & 29.3 \\
\hline+ & $\mathrm{LiCl}^{\mathrm{C}}$ & 0.3 \\
\hline+ & $\mathrm{KC}_{2} \mathrm{H}_{3} \mathrm{O}_{2}$ & 7.6 \\
\hline+ & $\mathrm{NaC}_{2} \mathrm{H}_{3} \mathrm{O}_{2}$ & 4.9 \\
\hline+ & $\mathrm{KI}$ & 3.1 \\
\hline+ & $\mathrm{Na}_{2} \mathrm{SO}_{4}$ & 5.2 \\
\hline+ & $\mathrm{KNO}_{3}$ & 18.9 \\
\hline+ & $\mathrm{Ca}_{3}\left(\mathrm{PO}_{4}\right)_{2}$ & 0.1 \\
\hline - & $\mathrm{CaCl}_{2}$ & 0.2 \\
\hline
\end{tabular}

${ }^{a}(t)$ indicate $t$-Factor added, $(-)$ indicate either $t-$ Factor or salt is omitted from the mixture. The average endogenous $\mathrm{Cl}^{-}$concentration based on several batches of yeast was $0.92 \mathrm{mg} / \mathrm{ml}$ of UM-05 filtrate. The $10 \mathrm{mg} / \mathrm{ml}$ of exogenous $\mathrm{KCl}$ added is based on the total yeast cell suspension. Other salts tested were adjusted to approximately the $\mathrm{KCl}$ concentration.

${ }^{b} \mathrm{KCl}$ in the absence of $t$-Factor was dissolved in $2 \mathrm{ml}$ of $\mathrm{H}_{2} \mathrm{O}$ and then mixed with pellet material as described under "Assay for t-Factor Activity by the Solubilization of COASPC."

CAnions associated with cations such as $\mathrm{Li}, \mathrm{Hg}, \mathrm{Pb}, \mathrm{Zn}$, Fe appear to inhibit the catalytic activity of COA-SPC (66). 
greater than the amount of protein which would be accounted for by COA-SPC alone. Solubilized extraneous protein was shown to be due to mechanical stirring and salt concentration of the mixture (see Table III, Procedure IIIB, page 93).

The chloride ion, not $\mathrm{KCl}$, appears to be essential for the solubilization of COA-SPC. To investigate this, chloride salts other than $\mathrm{KCl}$ were tested. Mono and dichloride salts at approximately equivalent chloride ion concentrations were mixed with pellet material and t-Factor, and were shown to function equally well in the solubilization of COA-SPC. With the exception of $\mathrm{KNO}_{3}$, the addition of salts not containing chloride (e.g., KAC, NaAc, $\mathrm{Na}_{2} \mathrm{SO}_{4}, \mathrm{KI}$ ) did not elevate the level of COA-SPC activity above that shown for endogenous chloride (Table IX). Consequently, it would appear that the salts tested which do not contain $\mathrm{Cl}^{-}$or $\mathrm{NO}_{3}{ }^{-}$do not function for solubilization of COA-SPC. Utilizing COA-SPC solubilized by $\mathrm{t}$-Factor and $\mathrm{KCl}$, varying amounts of $\mathrm{CaCl}_{2}$ and $\mathrm{MnCl}_{2}$ were added to the solubilized COA-SPC. Because the activity of the COA-SPC was not stimulated by the presence of these two salt forms, it was assumed that the difference in COA-SPC activity in Table IX between the $\mathrm{KCl}$ preparations and the $\mathrm{MnCl}_{2}$ and $\mathrm{CaCl}_{2}$ were not due to activation. Instead, since the salt forms were weighed rather than titrated to the appropriate concentrations, an error may have arisen, or the inconsistencies of the COA-SPC content of pellet preparations would also cause some could cause variation. Since the 
specific activities were comparable, these differences were judged insignificant. In the case of $\mathrm{LiCl}$, the chloride may have solubilized the COA-SPC, but because $\mathrm{Li}^{+}$is inhibitory (66) to the catalytic action of $\mathrm{COA}-\mathrm{SPC}$, no activity would be expected.

In other studies, experiments were conducted using $\left[{ }^{36} \mathrm{Cl}\right]-\mathrm{NaCl}$ to determine if the chloride ion exerts its action by binding to COA-SPC, heavy components of the yeast cell lysate or t-Factor. Results of these experiments did not indicate that $\left[{ }^{36} \mathrm{Cl}^{-}\right]$was binding to any of these fractions. Therefore, if $\left[{ }^{36} \mathrm{Cl}^{-}\right]$binding does take place, the bond between $\left[{ }^{36} \mathrm{Cl}^{-}\right]$and its site of binding is broken during the recovery of COA-SPC, other cell components or t-Factor.

Moreover, once t-Factor has been used for the solubilization of COA-SPC, it may be recovered by vacuum dialysis and reused without an apparent loss of activity.

\section{Compounds Tested for t-Factor Activity}

Table $X$ shows the various compounds tested for t-Factor activity. The biological compounds were selected based on their characteristics of molecular weight, heat stability, solubility in water, ultraviolet absorption at $260 \mathrm{m \mu}$ and ease of extractability from yeast. The detergents Triton $\mathrm{x}$ 100, cetylpyridinium chloride (CPC), sodium deoxycholate, and the reducing agents ethylenediamine tetracetic acid (EDTA), $B$-mercaptoethanol, and glutathione were also chosen because 
TABLE $X$

COMPOUNDS TESTED FOR $t$-FACTOR ACTIVITY

Coenzyme A

Acetyl-COA

Malonyl-COA

Cyclic-AMP

Adenosine- $5^{\circ}$-Monophosphate (AMP)

Adenosine-5'-Diphosphate (ADP)

Adenosine-5'-Triphosphate (ATP)

Adenine

Thymine

Guanine

Guanosine-5'-Triphosphate (GTP)

Guanosine-5'-Diphosphate (GDP)

Cytidine-5'-Triphosphate (CTP)

Cytidine-5 $5^{\prime}-D$ iphosphate (CDP)

Uridine-5'-Triphosphate (UTP)

Uridine-5'-Diphosphate (UDP)

Uridine-5'-Monophosphate (UMP)

Nicotinamide Adenine Dinucleotide

(Red) (NADH)

Nicotinamide Adenine Dinucleotide (Ox) (NAD)

Flavin Mononucleotide (FMN)

Flavin Adenine Dinucleotide (FAD)

Nicotinamide Adenine Dinucleotide

Phosphate (NADP)

Tetrahydrofolic Acid

N-5-Methyl Tetrahydrofolic Acid

Thiamine 
TABLE $\times$ (continued)

Folic Acid

Thiamine Pyrophosphate

Sodium Deoxycholate

Ethylenediamine Tetracetic Acid (EDTA)

Glutathione (GSH)

B-Mercaptoethanol

Cetylpyridinium Chloride (CPC)

Triton $\mathrm{X}-100$

a Each compound was tested by dissolving the compound in deionized water to a concentration of $0.1 \mathrm{mg} / \mathrm{ml}$. The detergents and reducing agents were tested at a concentration of $1 \mathrm{mg} / \mathrm{ml}$. The solution was combined with pellet material containing COA-SPC and $10 \mathrm{mg} \mathrm{KCl}$ per milliliter of yeast suspension was added. The suspension was mixed at $4{ }^{\circ} \mathrm{C}$ for 18 hours and centrifuged at $105,000 \times \mathrm{g}$ at $4^{\circ} \mathrm{C}$ for one hour. The supernatant was tested for solubilized COA-SPC as described in "Assay for COA-SPC Activity." 
these agents are commonly used in various systems to solubilize proteins. Each compound was first tested individually and then, many were tested as various combinations with other compounds in Table $x$. As Table $x$ shows, none of the compounds tested were able to be substituted for t-Factor as measured by the indirect assay method.

Testing t-Factor and Solubilized COA-SPC for proteolytic Activity

In Figure 12, a photograph of the casein agar plate used to detect proteolytic activity is shown. The positive and negative controls (see "Proteolytic Activity Assessment") are contained in Row 3. In Row 3, sample well 2 is the negative control, and in sample wells 3,4 , and 5 are progressively increasing concentrations of the positive control. The positive controls show the clearing zone that appears around the sample well when proteolytic attack has occurred. Although Row 3, sample well 5 was poorly photographed, sample wells 3 and 4 demonstrate that the diameters of the clearing zones are increased when increased proteolytically active enzyme are present.

Sample well 3 of Rows 1 and 2 show that crude supernatant containing t-Factor has proteolytic activity. Sample well 2 of Rows 1 and 2 show that heat treating the crude supernatant destroys the proteolytic activity, and the lack of proteolytic activity remaining with the UM-05 filtrate 


\section{R O W 1}

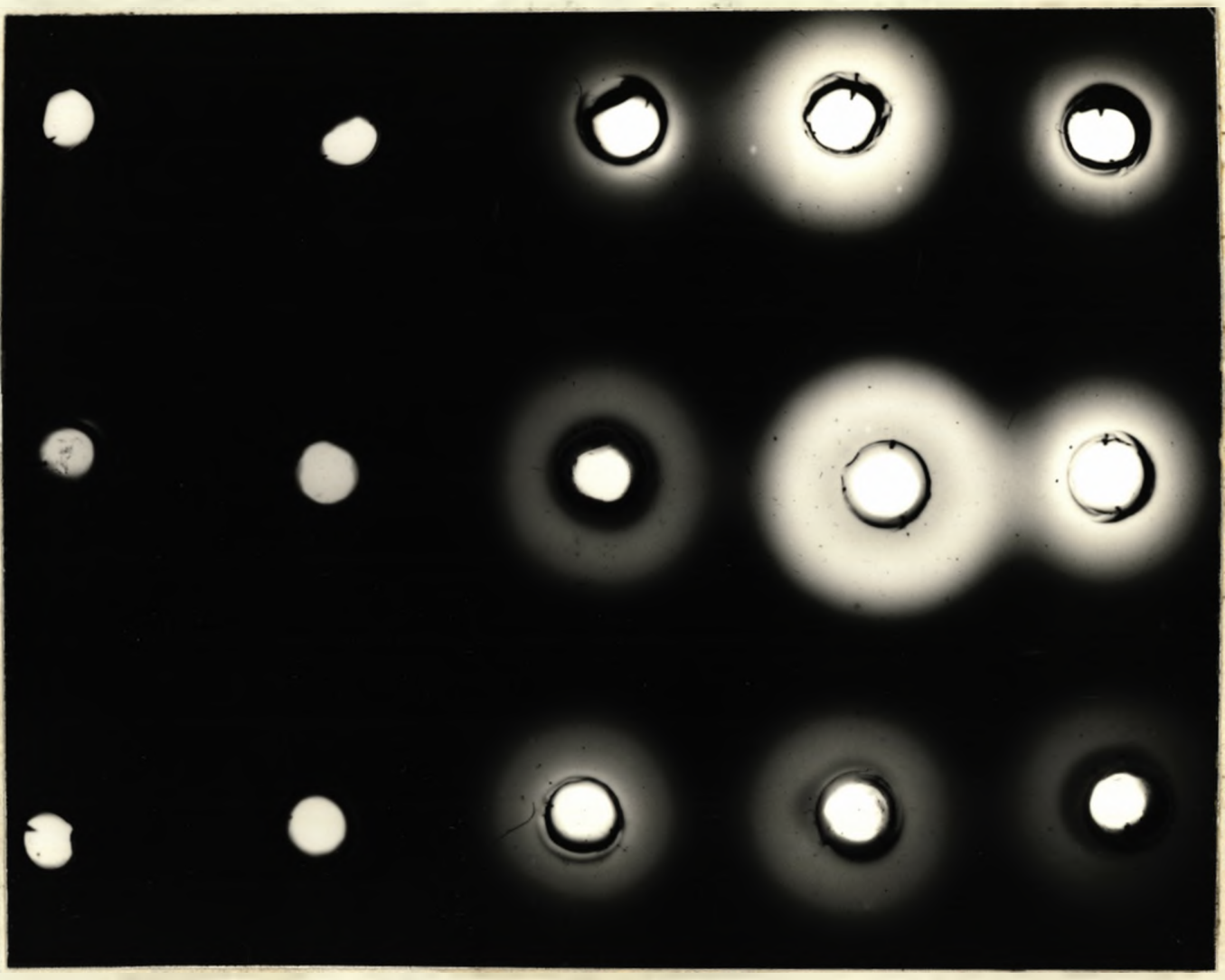

Figure 12. Testing proteolytic activity in various t-Factor fractions and COA-SPC solubilized by crude and purified t-Factor.

The casein agar plate was photographed by direct light; the clearing zones are in white and the agar plate in black. The samples were applied to each row in the plate and each well assigned a number reading from left to right. Row 1: 10 ul UM-05 filtrate; $10 \mu l$ heat treated supernatant; $10 \mu l$ crude supernatant; $10 \mu l$ crude CoA-SPC; $10 \mu l$ COA-SPC solubilized with purified t-Factor. Row 2: Same as Row 1 except the amount applied of each sample was $30 \mu \mathrm{l}$. Row 3: $30 \mu \mathrm{l}$ of heat treated CoA-SPC; $30 \mu \mathrm{l}$ negative control; $10 \mu l$ positive control; $20 \mu l$ positive control; $30 \mu l$ positive control. 
(sample 1, Rows 1 and 2). Sample well 4 of Rows 1 and 2 show COA-SPC solubilized with crude t-Factor (crude supernatant) and sample well 5 of Rows 1 and 2 show COA-SPC solubilized by t-Factor contained in the UM-05 filtrate.

Comparing the diameters of the clearing zones around sample wells 4 and 5 , the proteolytic activity shown in the COA-SPC solubilized by purified $t-F a c t o r$ is greatly reduced when compared to that solubilized by the crude supernatant. The reduced proteolytic activity could provide preparations more stable for storage. Since no proteolytic activity is added to pellet containing COA-SPC when purified t-Factor is used to solubilize COA-SPC, it is reasonable to assume that the proteolytic activity in sample well 5 is the result of the treatment of pellet material with $t$-Factor and $\mathrm{kCl}$. If the solubilization of COA-SPC is accomplished by the hydrolysis of the enzyme from its attachment site in the insoluble yeast residue, t-Factor may function to solubilize or activate a proteolytic enzyme to carry out this function

In Row 3, sample well 1, a sample of heat denatured CoASPC was applied and no proteolytic activity was evident.

Treatment of t-Factor with Charcoal

Amicon UM-05 filtrate containing t-Factor has significant ultraviolet absorption at $260 \mathrm{~m} \mu$. For example, a typical UM-05 filtrate diluted 100 times has $A_{260}$ equal to 1.450 , therefore the original filtrate contains approximately 145 
absorbance units. After exposure to charcoal (see "Treatment of t-Factor with Charcoal") for 30 minutes, the $A_{260}$ of the "charcoal extract" was decreased to 1.25 absorbance units. Longer exposure to the charcoal did not decrease the $A_{260}$ further. Since t-Factor appears in the "charcoal extract", this 100-fold decrease in the absorbance would suggest that t-Factor does not have the characteristic absorbance or that it represents only a small portion of the overall $A_{260}$ content of the UM-05 filtrate. The adsorption step results in a further purification of t-Factor. Following this preliminary observation on the UM-05 filtrate, the Sephadex G-10 fraction containing t-Factor was exposed to charcoal. The charcoal removed the ultraviolet absorbing material and the t-Factor activity was not decreased from the activity observed in the G-10 fraction (see Table XII, page 127).

Treatment of t-Factor with Ion-Exchange Resin

When the "charcoal extract" containing t-Factor activity was subjected to ion-exchange chromatography (see Materials and Methods, "Treatment of t-Factor with Ion-Exchange Resin"); the activity appeared in the "ion-exchange extract". The t-Factor activity of this fraction was decreased based on its ability to solubilize COA-SPC. When the "ion-exchange eluate" was recombined with the "ion-exchange extract", the activity in the original "charcoal extract" was recovered. This observation suggests t-Factor may require a second 
component for optimal activity or it may have some affinity for the ion-exchange resin (see Table XII).

\section{Purification of t-Factor}

The assay for the presence of $t$-Factor activity is shown by the ability of a particular fraction to solubilize catalytically active COA-SPC. This indirect method for assay does not provide a convenient method for establishing the t-Factor content in a particular fraction. To estimate the extent to which a particular t-Factor fraction was purified, one must first prove that the fraction solubilizes COA-SPC. Once COASPC activity was established, the $t$-Factor active fraction was lyophilized to dryness and weighed. Table XI shows the estimated purity of $t$-Factor by this method as 677-fold over crude preparations.

Purification of COA-SPC Utilizing t-Factor

The evidence presented that t-Factor solubilizes COA-SPC suggested that a single "one-step" purification of COA-SPC could be obtained by combining purified t-Factor with washed pellet material obtained from "Preparation of pellets containing COA-SPC." Table XII shows the purification of COASPC with t-Factor obtained from the Sephadex G-10 chromatography and that following treatment with charcoal provides the most pure COA-SPC preparations. Although the COA-SPC prepared by the $t$-Factor purified by ion-exchange chromatography is purified over crude COA-SPC preparations, the 
TABLE XI

ESTIMATE OF THE PURIFICATION OF $t$-FACTOR

BASED UPON INDIRECT ASSAY

\begin{tabular}{|c|c|c|c|c|}
\hline Fraction ${ }^{a}$ & $\begin{array}{l}\text { Total } \\
\text { Volume }\end{array}$ & $\begin{array}{l}\text { Total } \\
\text { Protein }\end{array}$ & $\begin{array}{l}\text { Total } \\
\text { Solids }\end{array}$ & Purification ${ }^{d}$ \\
\hline & $\underline{\mathrm{ml}}$ & $\underline{\mathrm{mg}}$ & $\underline{\mathrm{mg}}$ & -fold \\
\hline Crude supernatant & 25 & 645 & 3250 & 1 \\
\hline $\begin{array}{l}\text { Heat treated } \\
\text { supernatant }\end{array}$ & 21.5 & 150 & 2400 & 1.4 \\
\hline $\begin{array}{c}\text { Amicon UM-05 } \\
\text { filtrate }\end{array}$ & 10 & - & 581 & 5.6 \\
\hline Sephadex G-10 & 1 & - & 5.2 & 625 \\
\hline Charcoal extract & 1 & - & 4.8 & 677 \\
\hline
\end{tabular}

asee Figure 7, page 92, Figure 8, page 99, "Permeation Chromatography of $t$-Factor on Sephadex G-10," and "Treatment of t-Factor with Charcoal." tein."

${ }^{b}$ Determined as described under "Determination of Pro-

chyophilized to dryness in tared bottles and weighed.

dpurification is based on the weight ratios of equivalently active t-Factor fractions. 
TABLE XII

PURIFICATION OF THE COA-SYNTHESIZING PROTEIN COMPLEX

(COA-SPC) BY PURIFIED t-FACTOR

\begin{tabular}{|c|c|c|c|c|c|c|}
\hline Fraction ${ }^{a}$ & Volume $\mathrm{f}$ & Protein 9 & $\begin{array}{l}\text { CoA-sPC } \\
\text { Activity }\end{array}$ & $\begin{array}{l}\text { Specific } \\
\text { Activity }\end{array}$ & Yield & Purification \\
\hline 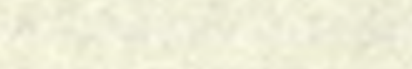 & $\underline{\mathrm{ml}}$ & $\mathrm{mg} / \mathrm{ml}$ & (nmoles) & (nmoles/mg/h) & $\underline{8}$ & -fold \\
\hline Crude Extract ${ }^{b}$ & 175 & 131.0 & 28.0 & 4.4 & 100 & 1.0 \\
\hline $\begin{array}{l}\text { Pellet Extract } \\
\qquad(\mathrm{G}-10)^{c}\end{array}$ & 175 & 4.1 & 38.0 & 185.5 & 132 & 42.2 \\
\hline $\begin{array}{l}\text { Pellet Extract } \\
(\text { Charcoal) }\end{array}$ & 175 & 3.8 & 35.2 & 185.5 & 132 & 42.2 \\
\hline $\begin{array}{l}\text { Pellet Extract } \\
(\text { Ion-Exchange) }\end{array}$ & 175 & 3.6 & 26.7 & 148.4 & 106 & 33.8 \\
\hline
\end{tabular}

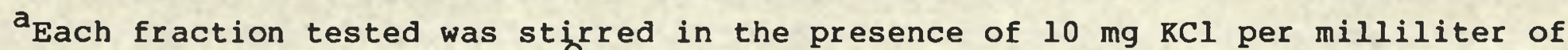
yeast suspension for 18 hours at $4^{\circ} \mathrm{C}$ as described under "Assay for $t-F a c t o r$ Activity by the Solubilization of COA-SPS." The extracts were obtained by centrifugation at $105,000 \times \mathrm{g}$ for one hour at $4 \mathrm{C}$.

b This fraction was obtained by stirring the crude yeast cell lysate obtained by treatment of the compressed Bakers' yeast with ether and dry ice.

$C_{\text {This }}$ fraction was obtained by mixing pellet material with the t-Factor active portion obtained by Sephadex G-10 chromatography of the Amicon UM-05 filtrate. 
$d_{\text {This }}$ fraction was obtained by mixing pellet material with the t-Factor contained in "charcoal extract" (see "Treatment of t-Factor with Charcoal").

$e_{\text {This }}$ fraction was obtained by mixing pellet material with the "ion-exchange extract" of the "charcoal extract" (see "Treatment of t-Factor with Ion-Exchange Resin").

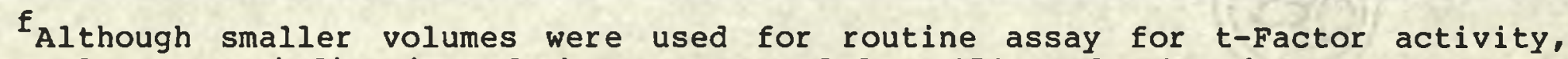
these volumes are indicative of those recovered from $454 \mathrm{~g}$ of Bakers' yeast.

${ }^{g}$ Determined as described under "Determination of Protein."

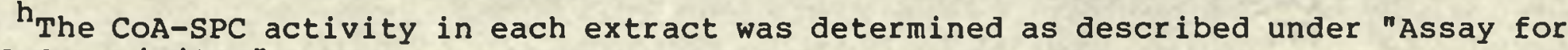
COA-SPC ACtivity." 
procedure is not attractive since there is a decrease in COASPC activity when compared to the Sephadex G-10 and charcoal preparations.

This method of purification of COA-SPC utilizing tFactor is attractive from the standpoint that pellets containing COA-SPC activity may be stored, and purified t-Factor added when a COA-SPC preparation is desired. This initial purification may provide a convenient starting point to examine other characteristics of COA-SPC that would otherwise require time consuming purification procedures which usually result in significant losses of the desired enzyme.

\section{Alternate Method for the Production of COA-SPC}

The ether-solid carbon dioxide method for the production of COA-SPC is satisfactory on a laboratory scale. Therefore, it was of interest to learn if other methods of obtaining a cell lysate still required t-Factor for the solubilization of COA-SPC. Of the methods attempted, only the alternate method as described proved to be successful and has the potential for large scale development.

Fresh compressed Bakers' yeast ( $30 \mathrm{~g})$ was crumbled, spread uniformly over the surfaces of three trays and each was dried at different temperatures as shown in Table XIII. The attempt to dry yeast at $4^{\circ} \mathrm{C}$ for 72 hours with or without vacuum ( 30 p.s.i.) was not successful. Only 25.80 percent of the weight was lost after 72 hours, and no detectable COA-SPC 
TABLE XIII

EFFECT OF DRYING TIME AND TEMPERATURE ON EXTRACTION

OF COA-SPC FROM FRESH BAKERS' YEAST

\begin{tabular}{|c|c|c|c|c|c|c|c|c|c|c|c|c|}
\hline \multirow[b]{3}{*}{ TIME } & \multicolumn{8}{|c|}{ DRYING TEMPERATURE ${ }^{+}$} & \multicolumn{4}{|c|}{$50^{\circ}$} \\
\hline & \multicolumn{4}{|c|}{$4^{\circ}$} & \multicolumn{4}{|c|}{$\begin{array}{c}\text { REHYDRATION TEMPERATURE } \\
4^{\circ} \\
\end{array}$} & \multicolumn{4}{|c|}{$4^{\circ}$} \\
\hline & $\begin{array}{l}\text { Weight }{ }^{c} \\
\text { Remaining }\end{array}$ & $\begin{array}{l}\text { CoA-SPCd } \\
\text { Activity }\end{array}$ & $\begin{array}{l}\text { Soluble } \\
\text { Protein }\end{array}$ & $\begin{array}{l}\text { Specific } \\
\text { Activity }\end{array}$ & $\begin{array}{l}\text { Weight } \\
\text { Remaining }\end{array}$ & $\begin{array}{l}\text { COA-SPC } \\
\text { ACtivity }\end{array}$ & $\begin{array}{l}\text { Soluble } \\
\text { Protein }\end{array}$ & $\begin{array}{l}\text { Specific } \\
\text { Activity }\end{array}$ & $\begin{array}{l}\text { Welght } \\
\text { Remalning }\end{array}$ & $\begin{array}{l}\text { COA-SPC } \\
\text { Activity }\end{array}$ & $\begin{array}{l}\text { Soluble } \\
\text { Protein }\end{array}$ & $\begin{array}{l}\text { Specific } \\
\text { Activity }\end{array}$ \\
\hline & & (nmoles) & $(\mathrm{mg} / \mathrm{ml})$ & $\begin{array}{l}\text { (nmoles/ } \\
\mathrm{mg} / \mathrm{h} \text { ) }\end{array}$ & & (nmoles) & $(\mathrm{mg} / \mathrm{ml})$ & $\begin{array}{l}\text { (nmoles) } \\
(\mathrm{mg} / \mathrm{h})\end{array}$ & & (nmoles) & $(m g / m 1)$ & $\begin{array}{c}\text { (nmoles/ } \\
\mathrm{mg} / \mathrm{h} \text { ) }\end{array}$ \\
\hline 12 & 95.64 & 0 & 2 & 0 & 53.00 & 9.9 & 40 & 5.0 & 33.70 & 23.5 & 68 & 6.9 \\
\hline 24 & 91.46 & 0 & 19 & 0 & 37.70 & 13.0 & 50 & 5.2 & 31.60 & 23.5 & 69 & 6.8 \\
\hline 36 & 87.12 & 0 & 11 & 0 & 34.00 & 21.1 & 61 & 6.9 & 31.60 & 23.5 & 69 & 6.8 \\
\hline 48 & 83.60 & 0 & 11 & 0 & 33.70 & 23.5 & 68 & 6.9 & 31.20 & 23.5 & 63 & 7.5 \\
\hline 60 & 78.90 & 0 & 11 & 0 & 33.90 & 21.1 & 61 & 6.9 & 31.00 & 23.5 & 64 & 7.3 \\
\hline
\end{tabular}
trays.

+Drying was accomplished by crumbling fresh Bakers' yeast and spreading the yeast to a uniform surface in glass or plastic

Extraction of COA-SPC was carried out on the yeast cell lysate by mechanical mixing at $4^{\circ}$ for $18 \mathrm{~h}$ with $10 \mathrm{mg}$ KCl/al of rehydrated yeast suspension. Centrifugation followed at $105,000 \times \mathrm{g}$ one hour at $4^{\circ} \mathrm{C}$ to recover the 1 iquid portion of the rehydrated mixture.

behydration was accomplished utilizing delonized $\mathrm{H}_{2} \mathrm{O}$ in a volume equivalent to the weight loss during the drying process. with the notable exception that the weight lost due to moisture by the yeast dried at 4 was insufficient for mechanical mixing to be achieved when rehydrated, additiongl deionized water was added to the yeast paste. All dried yeast solids were ground with a porcelain mortar and pestle at $24^{\circ}$ prior to rehydration.

cThe initial weight of the fresh compress Bakers' yeast was $30 \mathrm{~g} ; 26 \mathrm{ml}$ yeast cell volume.

dAs described under "Assay for CoA-SPC Activity," the values listed represent the formation of ( $^{35}$ s)-dephospho-CoA-bound to COA-SPC.

"Soluble protein measurements are described under "Determination of Protein." 
activity was obtained. If the drying time had been extended, COA-SPC activity may have been observed. The highest COA-SPC activity was obtained when the yeast was dried at $50^{\circ} \mathrm{C}$ for 72 hours; however, the activity level of various preparations was inconsistent. The most consistent specific activity level for COA-SPC was observed when yeast was dried at $24^{\circ} \mathrm{C}$ for 36 hours to 72 hours. Forty hours at $24^{\circ} \mathrm{C}$ was chosen as the drying conditions for this study. If faster drying rates are desired, it is possible to dry the yeast in a vacuum while maintaining the yeast temperature at a level at which autolysis occurs.

As the yeast dried, its color darkened. Yeast $(30 \mathrm{~g})$ was dried until at least 66 percent of its original wet weight was removed (Table XIII). Some of the weight remaining was attributed to water (approximately three percent) and to starch and other components of the growth medium present in the commercial yeast cake. After drying, the yeast was used immediately for the preparation of COA-SPC, or it was stored under dry conditions for an extended time without harmful effects to its COA-SPC content.

Preparation of the COA-SPC was facilitated by grinding the dried yeast with a mortar and pestle, or by some other method, until the yeast appeared as a uniform powder prior to rehydration. The grinding process appeared to facilitate rehydration and had a destructive effect on the cell wall. 
Table XIV compares recovery of COA-SPC from yeast prepared by the original method using ether-solid $\mathrm{CO}_{2}$ with $\mathrm{COA}-$ SPC recovered by the alternate procedure before and after grinding. As shown, grinding of the dried yeast did not appear to be essential. Whether the standard procedure of grinding with a mortar and pestle was used, or alumina or sand paper was used to facilitate cell breakage, the amount of COA-SPC activity recovered was approximately the same. Moreover, approximately the same level of COA-SPC activity was recovered from the yeast whether the original method or a modified procedure was used.

It was interesting to note that yeast dried by lyophilization instead of by the slow drying process used in the modified procedure did not have COA-SPC activity whether ground or not ground. Slow drying at higher temperatures appeared to provide a condition favorable for the autolytic process in the yeast cell which contributed to the recovery of COA-SPC.

Experiments studying the effect of grinding on the recovery of COA-SPC are shown in Table XV. There was a difference in the level of COA-SPC activity recovered between unground (particle size $5600 \mu$ to $425 \mu$ ) yeast and ground (particle size $425 \mu$ to $125 \mu$, and $125 \mu$ to $38 \mu$ ) yeast. Ground Bakers' yeast of particle size ranging from $425 \mu$ to $38 \mu$ yielded the greatest amount of COA-SPC activity. Therefore, these data indicate that there was a decided advantage 
TABLE XIV

EFFECT OF GRINDING ON THE ABILITY TO EXTRACT
COA-SPC FROM DRIED YEAST SOLIDS

\begin{tabular}{|c|c|c|c|}
\hline Condition & $\begin{array}{l}\text { COA-SPC } \\
\text { Activity }\end{array}$ & $\begin{array}{l}\text { Soluble } \\
\text { Protein }\end{array}$ & $\begin{array}{l}\text { Specific } \\
\text { Activity }\end{array}$ \\
\hline & (nmoles) & $(\mathrm{mg} / \mathrm{ml})$ & (nmoles/mg/h) \\
\hline Original Method ${ }^{b}$ & 25.6 & 74 & 6.9 \\
\hline No grinding ${ }^{c}$ & 15.3 & 68 & 4.5 \\
\hline $\begin{array}{l}\text { Grinding with mortar } \\
\text { \& pestle }\end{array}$ & 27.1 & 75 & 7.2 \\
\hline $\begin{array}{l}\text { Grinding with one part } \\
\text { alumina \& nine parts } \\
\text { dry yeast solide }\end{array}$ & 29.4 & 81 & 7.3 \\
\hline $\begin{array}{r}\text { Grinding freeze-dried } \\
\text { yeast }\end{array}$ & 0 & 81 & 0 \\
\hline Sandpaper disc ${ }^{9}$ & 25.9 & 80 & 6.5 \\
\hline
\end{tabular}

${ }^{a}$ Rehydration by adding deionized $\mathrm{H}_{2} \mathrm{O}\left(4^{\circ} \mathrm{C}\right)$ equivalent to the weight lost by drying $30 \mathrm{~g}$ compressed yeast. Following the addition of $\mathrm{H}_{2} \mathrm{O}$, the yeast was mixed 18 hours at $4^{\circ} \mathrm{C}$ with $10 \mathrm{mg} / \mathrm{ml}$ of yeast suspension, centrifuged at $105,000 \mathrm{x} \mathrm{g}$ for one hour at $4^{\circ} \mathrm{C}$ to recover the soluble portion.

'Fresh Bakers' yeast was prepared by the ether-solid $\mathrm{CO}_{2}$ method (see "Preparation of pellets containing CoA-SPC").

${ }^{C}$ Dried yeast solids (34 percent of the original wet weight) were rehydrated without grinding following the drying period.

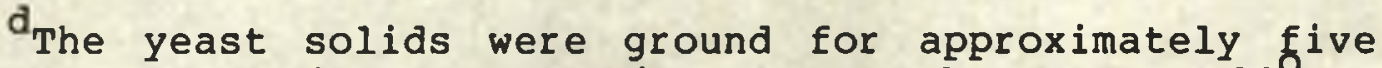
minutes by hand with a porcelain mortar and pestle at $24^{\circ} \mathrm{C}$.

eAlcoa chromatographic alumina $\mathrm{F}-20$ was not removed prior to rehydration and mixing.

${ }^{\mathrm{f}}$ Compressed yeast was shell frozen and lyophilized to dryness and ground prior to rehydration.

${ }^{9}$ Coarse sand paper glued to the bottom of a container and to the flat surface of a disc which was attached to a drill press was used to grind the dried yeast. The dried yeast was sandwiched between these two sandpaper discs and ground for five minutes at low speed to prevent the generation of excess heat. 
TABLE XV

EFFECT OF PARTICLE SIZE OF DRIED BAKERS' YEAST ON THE EXTRACTION OF COA-SPC

\begin{tabular}{cccc}
$\begin{array}{c}\text { Particle Size Range } \\
\text { (microns) }\end{array}$ & $\begin{array}{l}\text { CoA-SPC } \\
\text { Activity }\end{array}$ & $\begin{array}{c}\text { Soluble } \\
\text { Protein }\end{array}$ & $\begin{array}{c}\text { Specific } \\
\text { Activity }\end{array}$ \\
\hline $5600-425$ & (nmoles) & (mg/ml) & (nmoles/mg/h) \\
$425-125$ & 15.3 & 68 & 4.5 \\
$125-38$ & 22.7 & 76 & 6.0 \\
\hline
\end{tabular}

'Dried, unground Bakers' yeast (34 percent of the original wet weight) contained particles ranging from 5600 microns to 88 microns. Ground Bakers' yeast contained particles ranging from 425 microns to 38 microns. Particle sizes were determined through use of the U. S. Standard Sieve Series, W. S. Tyler Company. Grinding was achieved by use of a porcelain mortar and pestle at $24{ }^{\circ} \mathrm{C}$. Extraction of COA-SPC was with deionized $\mathrm{H}_{2} \mathrm{O}$ at $4^{\circ} \mathrm{C}$, followed by mixing for 18 hours at $4^{\circ} \mathrm{C}$ with $10 \mathrm{mg} \mathrm{KCl}$ per milliliter of yeast suspension. The soluble portion was recovered by centrifugation at $105,000 \times \mathrm{g}$ for one hour at $4^{\circ} \mathrm{C}$. 
to grinding the dried yeast which contributed to the destruction of the cell wall, and that the more extensive the grinding procedure, the more efficient the recovery of COA-SPC.

The dried yeast powder was rehydrated by the addition of an amount of deionized water equivalent to the original weight of the compressed yeast ( 34 percent). As shown in Table XVI, rehydration to 34 percent yeast solids was the chosen condition. Higher concentrations of yeast were more difficult to stir, and the amount of COA-SPC recovered was less. Whereas, lower concentrations of yeast solids resulted in decreased concentration of $t$-Factor below that essential for COA-SPC solubilization. The rehydration process was conducted at $4^{\circ} \mathrm{C}$ as shown in Table XIII, page 130. Rehydration temperature of $4^{\circ} \mathrm{C}$ to $65^{\circ} \mathrm{C}$ were tested as shown in Table XVII; however, the most effective temperature range was between $4^{\circ} \mathrm{C}$ and $24^{\circ} \mathrm{C}$. After the addition of water, the mixture was stirred until the yeast was uniformly resuspended. Then $\mathrm{KCl}$ was added to a concentration of $10 \mathrm{mg} / \mathrm{ml}$ of yeast suspension of wet yeast and the stirring was continued for 18 hours at $4^{\circ} \mathrm{C}$. Temperatures other than $4^{\circ} \mathrm{C}$ (i.e., $24^{\circ} \mathrm{C}$ and $36^{\circ} \mathrm{C}$ ) were tested during the stirring step, but the alternative temperatures were detrimental to COA-SPC (Table XVIII). Following the 18-hour stirring step, the mixture was centrifuged at $105,000 \times \mathrm{g}$ for one hour at $4^{\circ} \mathrm{C}$. The supernatant liquid was recovered and the protein content and COA-SPC 
TABLE XVI

EFFECT OF THE CONCENTRATION OF DRIED BAKERS' YEAST SOLIDS IN SUSPENSION ON THE EXTRACTION OF COA-SPC ACTIVITY

\begin{tabular}{cccc}
$\begin{array}{c}\text { Concentration } \\
(\mathrm{w} / \mathrm{w} 8)\end{array}$ & $\begin{array}{c}\text { CoA-SPC } \\
\text { Activity }\end{array}$ & $\begin{array}{c}\text { Soluble } \\
\text { Protein }\end{array}$ & $\begin{array}{c}\text { Specific } \\
\text { Activity }\end{array}$ \\
\hline & (nmoles/ml) & (mg/ml) & (nmoles $/ \mathrm{mg} / \mathrm{h})$ \\
34 & 23.5 & 68 & 6.9 \\
20 & 4.0 & 27 & 3.0 \\
17 & 0.9 & 14 & 1.3 \\
15 & 0 & 13 & 0 \\
10 & 0 & 10 & 0 \\
8.5 & 0 & 6 & 0 \\
\hline \hline
\end{tabular}

'Dried Bakers' yeast solids ( 34 percent of the original wet weight) were ground with a porcelain mortar and pestle at $24^{\circ} \mathrm{C}$ to a particle size range of $425 \mathrm{microns}$ to $38 \mathrm{microns}$. The yeast particles were rehydrated with deionized $\mathrm{H}_{2} \mathrm{O}$ at $4{ }^{\circ} \mathrm{C}$ to the concentrations prescribed based on weight. ${ }^{2} \mathrm{KCl}$ was added to each yeast suspension at a concentration of $10 \mathrm{mg} / \mathrm{ml}$ of yeast suspension. The yeast suspension was mixed at $4^{\circ} \mathrm{C}$ for 18 hours and the soluble portion recovered by centrifugation at $105,000 \times \mathrm{g}$ for one hour at $4{ }^{\circ} \mathrm{C}$. A normal suspension of ground Bakers' yeast solids was 34 percent (w/w). 
TABLE XVII

EFFECT OF THE TEMPERATURE OF THE WATER OF

REHYDRATION ON THE EXTRACTION OF COA-SPC

FROM DRIED BAKERS' YEAST SOLIDS

\begin{tabular}{|c|c|c|c|}
\hline Water ${ }_{\left({ }_{C}\right)}^{\text {Temperature }}$ & $\begin{array}{l}\text { COA-SPC } \\
\text { Activity }\end{array}$ & $\begin{array}{l}\text { Soluble } \\
\text { Protein }\end{array}$ & $\begin{array}{l}\text { Specific } \\
\text { Activity }\end{array}$ \\
\hline & (nmoles) & $(\mathrm{mg} / \mathrm{ml})$ & (nmoles/mg/h) \\
\hline 4 & 25.6 & 74 & 6.9 \\
\hline 24 & 25.6 & 76 & 6.7 \\
\hline 36 & 22.5 & 75 & 6.0 \\
\hline 50 & 18.7 & 76 & 4.9 \\
\hline 65 & 0 & 32 & 0 \\
\hline
\end{tabular}

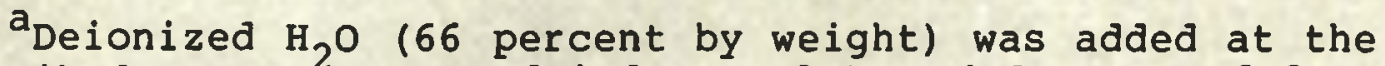
prescribed temperature to dried ground (particles ranged from 425 microns to 38 microns) Bakers' yeast solids equivalent to the weight lost during the drying procedure. $\mathrm{KCl}$ was added to a concentration of $10 \mathrm{mg} / \mathrm{ml}$ of yeast suspension and the suspension was mixed at $4{ }^{\circ} \mathrm{C}$ for 18 hours. The soluble portion was recovered by centrifugation at $105,000 \times \mathrm{g}$ for one hour at $4^{\circ} \mathrm{C}$.

$b_{\text {The water and }}$ dried $(34$ percent of the original wet weight) Bakers' yeast admixtures were maintained at the indicated water temperature until all solids were suspended. 
TABLE XVIII

EFFECT OF TEMPERATURE FOR MIXING THE REHYDRATED DRIED

BAKERS' YEAST ON THE EXTRACTION OF COA-SPC ACTIVITY

\begin{tabular}{cccc}
$\begin{array}{c}\text { Mixing } \\
\text { Temperature }\end{array}$ & $\begin{array}{l}\text { CoA-SPC } \\
\text { Activity }\end{array}$ & $\begin{array}{l}\text { Soluble } \\
\text { Portion }\end{array}$ & $\begin{array}{c}\text { Specific } \\
\text { Activity }\end{array}$ \\
\hline$\underline{\left.{ }^{\circ} \mathrm{C}\right)}$ & $\underline{\text { (nmoles) }}$ & $\underline{(\mathrm{mg} / \mathrm{ml})}$ & $\underline{(\text { nmoles } / \mathrm{mg} / \mathrm{h})}$ \\
4 & 25.6 & 74 & 6.9 \\
36 & 0 & 76 & 0 \\
\hline \hline
\end{tabular}

aDried Bakers' yeast (34 percent at the original wet weight) was ground at $24^{\circ} \mathrm{C}$ to a particle size range of 425 microns to 38 microns and rehydrated at $4{ }^{\circ} \mathrm{C}$ with deionized $\mathrm{H}_{2} \mathrm{O}$. $\mathrm{KCl}$ was added to a concentration of $10 \mathrm{mg} / \mathrm{ml}$ of yeast suspension. Each suspension was mixed at the prescribed temperature for 18 hours. The soluble portion was recovered by centrifugation at $105,000 \times \mathrm{g}$ for one hour at $4^{\circ} \mathrm{C}$. 
activity were determined as described under "Materials and Methods."

Table XIX shows the effect of initially removing $t-$ Factor from the Bakers' yeast cells. Freezing and thawing fresh Bakers' yeast in liquid nitrogen as shown in Figure 8 , page 99, produces insoluble and soluble portions of the yeast cell when centrifuged at $105,000 \times \mathrm{g}$ at $4^{\circ} \mathrm{C}$. The resulting supernatant liquid was treated according to the methods outlined in Figure 8, page 99, to yield the UM-05 filtrate. The insoluble residue was washed twice as described under "Preparation of pellets containing COA-SPC," and then dried for 40 hours at $24^{\circ} \mathrm{C}$. Table XIX shows that by recombining the UM05 filtrate with the liquid nitrogen-treated dried yeast cell residues, COA-SPC was solubilized. When the dried residues were mixed with water and $\mathrm{KCl}$, no COA-SPC activity was detected. Although COA-SPC was not detected after simply stirring the liquid nitrogen freeze-thaw lysate, the drying of the residue appeared to render COA-SPC accessible to tFactor.

Attempts to extract COA-SPC from Bakers' yeast cells by methods other than the two described have failed to yield active COA-SPC. Passage of yeast cells through a French pressure cell under 20,000 p.s.i., have failed to produce active COA-SPC before and after stirring for 18 hours. Although yeast cells are very difficult to rupture by this technique, requiring as much as 50,000 p.s.i. (99), the heat 
TABLE XIX

EFFECT OF THE INITIAL REMOVAL OF $t$-FACTOR OF FRESH

BAKERS' YEAST ON THE EXTRACTION OF COA-SPC FROM THE REMAINING DRIED SOLID RESIDUE

\begin{tabular}{lccc}
\hline \hline Condition & $\begin{array}{c}\text { COA-SPC } \\
\text { Activity }\end{array}$ & $\begin{array}{c}\text { Soluble } \\
\text { Protein }\end{array}$ & $\begin{array}{c}\text { Specific } \\
\text { Activity }\end{array}$ \\
\hline & (nmoles) & (mg/ml) & (nmoles/mg/h) \\
$\begin{array}{lcc}\text { Control } \\
\begin{array}{l}\text { Deionized water \& } \\
\text { dried yeast residue }\end{array}\end{array}$ & 23.5 & 68 & 6.9 \\
$\begin{array}{l}\text { Amicon UM-05 filtrate } c^{\&} \\
\text { dried yeast residue }\end{array}$ & 29.0 & 5 & 0.0 \\
\hline \hline
\end{tabular}

'Dried Bakers' yeast ( 34 percent of the original wet weight) was ground at $24{ }^{\circ} \mathrm{C}$ to a particle size range of 425 microns to 38 microns and rehydrated with deionized water at $4 . \mathrm{C}$. $\mathrm{KCl}$ was added to the suspension at a concentration of $18 \mathrm{mg} / \mathrm{ml}$ of yeast suspension. The suspension was mixed at $4 \mathrm{C}$ for 18 hours. The soluble portion was recovered by centrifugation at $105,000 \times \mathrm{g}$ for one hour at $4 \mathrm{C}$.

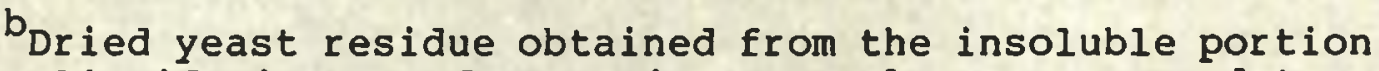
of the liquid nitrogen freeze-thaw procedure was ground to a particle size of $425 \mathrm{microns}$ to $38 \mathrm{microns}$. Deionized water at $4^{\circ} \mathrm{C}$ was added to the dried yeast residue $(9.5 \mathrm{~g})$ to obtain a total volume of $26 \mathrm{ml}$. $\mathrm{KCl}$ was added to a concentration of $10 \mathrm{mg} / \mathrm{ml}$ yeast suspension and mixed for 18 hours at $4^{\circ} \mathrm{C}$. Mixing was followed by centrifugation at $105,000 \times \mathrm{g}$ for one hour at $4{ }^{C} \mathrm{C}$ to obtain the liquid portion.

${ }^{C}$ Dried yeast residue obtained from the insoluble portion of the liquid nitrogen freeze-thaw procedure was ground to a particle size of 425 microns to 38 microns. Amicon UM-05 filtrate obtained from the liquid nitrogen freeze-thaw procedure was added at $4^{\circ} \mathrm{C}$ to the dried yeast residue $(9.5 \mathrm{~g})$ to obtain a total volume of $26 \mathrm{ml}$. $\mathrm{KCl}$ was added to a concentration of $10 \mathrm{mg} / \mathrm{ml}$ of yeast suspension and mixed for 18 hours at $4^{\circ} \mathrm{C}$. Mixing was followed by centrifugation at $105,000 \times \mathrm{g}$ for one hour at $4^{\circ} \mathrm{C}$ to obtain the liquid portion. 
generated at 20,000 p.s.i. was sufficient to denature CoASPC. Likewise, when yeast cells were subjected to sonic oscillations, no COA-SPC activity could be detected before or after stirring. The classic autolytic method of incubating yeast cells with toluene at $30^{\circ} \mathrm{C}(100)$ was also ineffective for the recovery of COA-SPC. 
CHAPTER V

\section{SUMMARY}

The investigations contained in this dissertation demonstrate two methods for the recovery of coenzyme A-synthesizing protein complex (COA-SPC). The first method involves the exposure of Bakers' yeast cells to ether and solid- $\mathrm{CO}_{2}$, and the second method involves the slow drying and rehydration of the dried yeast cells. Both methods require stirring for 18 hours for the gradual solubilization of the COA-SPC. The COA-SPC has been shown not to be catalytic in an in vitro system until first solubilized. The solubilization of CoASPC was found to require a low molecular weight component of the soluble portion of the yeast cell, named t-Factor.

According to these data, there appeared to be a commonality between the ether and solid $-\mathrm{CO}_{2}$ method, and the alternate method of slow drying and rehydration of yeast cells. Both procedures provided a number of biochemical and physical disorganizing effects to the very complex protein-polysaccharide lattice of the cell wall for the extraction of COA-SPC. For instance, the breakdown of phospholipids by phospholipase C (101) has been observed upon drying the yeast. Additionally, it has been established that diethyl ether and ethanol stimulate enzymatic degradation of phospholipids by yet 
unknown mechanisms (98). Other organic solvents such as chloroform, toluene and ethylacetate have been employed to initiate autolysis for the isolation of proteases (102), cytochrome C (103), $\beta$-fructofuranosidase and acid phosphatase (104). These solvents probably release various hydrolytic enzymes from organelles that function to lysis intact cells $(105)$.

Although the exact nature of the mechanisms involved for the extraction of COA-SPC from ether-solid $\mathrm{CO}_{2}$ treated cells and dried-rehydrated treated cells has not been established, the presence of $t$-Factor appeared to be essential. $t$-Factor has not been identified but $t$-Factor has been purified and several of its properties examined. The $t$-Factor has been purified by heat fractionation, dialysis, ultrafiltration, column chromatography, adsorption chromatography, paper chromatography and ion-exchange chromatography. The t-Factor was resistant to heat at $80^{\circ} \mathrm{C}$ for 24 hours and hydrolysis by trypsin and protease; its activity was destroyed by ashing. The molecular weight of t-Factor was estimated to be 400 to 1,000 by column chromatography. The solubilization of COASPC by t-Factor appeared to be concentration-dependent and required the presence of chloride ion. Little is known about the mechanism by which t-Factor solubilizes COA-SPC. However, if the solubilization is by enzymatic action, $t$-Factor could function as an activator for an enzyme which is also 
insoluble and closely associated with COA-SPC in the insoluble portion of the yeast cell. The role of the chloride ion may be as an inorganic activator of the closely associated enzyme.

It would appear that any method of cell breakage assisted by endogenous enzyme activity which neither denatures the multienzyme complex, nor destroys t-Factor could be a means for recovering COA-SPC. Although no evidence is available at this time, the possibility still remains that COA-SPC is compartmentalized in the yeast cell and not bound. If this should be the case, then any method which ruptures the subcellular organelles and is not destructive to COA-SPC activity could produce an active preparation of this multienzyme complex. The drying and grinding procedures described appeared to have an effect on the yeast cell similar to that of the original procedure of freezing the yeast in ether and solid $\mathrm{CO}_{2}$. Neither method denatured $\mathrm{COA}-\mathrm{SPC}$ and both methods rendered COA-SPC accessible to solubilization by t-Factor. A distinct advantage to the drying-rehydration procedure was realized when small preparations of COA-SPC were scaled up to commercial size batches not requiring the large volume of ether necessary in the original method. 
BIBLIOGRAPHY 


\section{BIBLIOGRAPHY}

1. Lipmann, F. 1945. Acetylation of sulfanilamide by liver homogenates and extracts. J. Biol. Chem. 160:173190.

2. Lipmann, F., and N. O. Kaplan. 1946. A common factor in the enzymatic acetylation of sulfanilamide and of choline. J. Biol. Chem. 162:743-744.

3. Lipmann, F., N. O. Kaplan, G. D. Novelli, L. C. Tuttle, and B. M. Guirard. 1947. Coenzyme for acetylation, a pantothenic acid derivative. J. Biol. Chem. 167:869870 .

4. Williams, R. J., C. M. Lyman, G. H. Goodyear, J. H. Truesdail, and D. Holaday. 1933. "Pantothenic acid", a growth determinant of universal biological occurrence. J. Am. Chem. Soc. 55:2912-2927.

5. Novelli, G. D., N. O. Kaplan, and F. Lipmann. 1949. The liberation of pantothenic acid from coenzyme A. J. Biol. Chem. 177:97-107.

6. Brown, G. M. 1959. Assay and distribution of bound forms of pantothenic acid. J. Biol. Chem. 234:379-382.

7. Williams, R. J. 1943. The chemistry and biochemistry of pantothenic acid. In F. F. Nord and C. H. Werkman (ed.), Advances in Enzymology, Vol. III, pp. 253-287, Interscience, New York, New York.

8. Lipmann, F., N. O. Kaplan, G. D. Novelli, L. C. Tuttle, and B. M. Guirard. 1950. Isolation of coenzyme A. J. Biol. Chem. 186:235-243.

9. DeVries, W. H., W. M. Govier, J. S. Evans, J. D. Gregory, G. D. Novelli, M. Soodak, and F. Lipmann. 1950. Purification of coenzyme A from fermentation sources and its further partial identification. J. Am. Chem. Soc. $72: 4838$.

10. Gregory, J. D., G. D. Novelli, and F. Lipmann. 1952. The composition of coenzyme A. J. Am. Chem. Soc. $\underline{74}: 854$. 
11. Kalckar, H. M. 1947. Differential spectrophotometry of purine compounds by means of specific enzymes. II. Determination of adenine compounds. J. Biol. Chem. 167: 445-459.

12. Williams, W. L., E. Hoff-Jorgensen, and E. E. Snell. 1949. Determination and properties of an unidentified growth factor by Lactobacillus bulgaricus. J. Biol. Chem. 177:933-940.

13. Brown, G. M., J. A. Craig, and E. E. Snell. 1950. Relation of the Lactobacillus bulgaricus factor to pantothenic acid and coenzyme A. Arch. Biochem. 27:473-475.

14. Snell, E. E., G. M. Brown, V. J. Peters, J. A. Craig, E. L. Wittle, J. H. Moore, V. M. McGlohon, and O. D. Bird. 1950. Chemical nature and synthesis of the Lactobacillus bulgaricus factor. J. Am. Chem. Soc. 72:53495350 .

15. Brown, G. M., and E. E. Snell. 1953. The chemical nature of the Lactobacillus bulgaricus factor. J. Am. Chem. Soc. 75:1691-1693.

16. Govier, W. M., and A. J. Gibbons. 1952. I. Activity of LBF (pantetheine) in acetylation of sulfanilamide by pigeon liver extract. Arch. Biochem. Biophys. 32:347348 .

17. Baddiley, J., and E. M. Thain. 1951. Coenzyme A. Part II. Evidence for its formation as a derivative of pantothenic acid-4'-phosphate. J. Chem. Soc. (London), pp. 2253-2258.

18. Gregory, J. D., and F. Lipmann. 1952. The nature of the sulfur in coenzyme A. J. Am. Chem. Soc. 74:4017-4019.

19. Novelli, G. D., J. D. Gregory, R. M. Flynn, and F. J. Schmetz. 1951. Structure of coenzyme A. Fed. Proc. $10: 229$.

20. Novelli, G. D., R. M. Flynn, and F. Lipmann. 1949. Coenzyme $A$ as growth stimulant for Acetobacter suboxydans. J. Biol. Chem. 177:493-494.

21. King, T. E., L. M. Locher, and V. H. Cheldelin. 1948. Pantothenic acid studies. III. A pantothenic acid conjugate active for Acetobacter suboxydans. Arch. Biochem. 17:483-485. 
22. King. T. E., and F. M. Strong. 1951. Synthesis and properties of pantothenic acid diphosphate. J. Biol. Chem. 189: 315-323.

23. Baddiley, J., and E. M. Thain. 1951. Conzyme A. Part III. Synthesis of pantothenic acid-2':4'-phosphate and further structural considerations. J. Chem. Soc. (London), pp. 3421-3424.

24. King., T. E., and F. M. Strong. 1951. Some properties of coenzyme A. J. Biol. Chem. 189:325-333.

25. Baddiley, J., and E. M. Thain. 1952. Coenzyme A. Part VI. The identification of pantothenic acid-4'- and $-2 ': 4^{\prime}$-phosphate from a hydrolyzate. J. Chem. Soc. (London), pp. 3783-3789.

26. Baddiley, J., and E. M. Thain. 1953. Coenzyme A. Part III. The synthesis of pantetheine $4^{\prime}$-phosphate (Acetobacter stimulatory Factor), a degradation product of the coenzyme. J. Chem. Soc. (London), pp. 1610-1615.

27. Baddiley, J., and E. M. Thain. 1953. Coenzyme A. Part III. The synthesis of pantetheine $4^{\prime}$-phosphate (Acetobacter stimulatory Factor), a degradation product of the coenzyme. J. Chem. Soc. (London), pp. 1610-1615.

28. Novelli, G. D., N. O. Kaplan, and F. Lipmann. 1950. Enzymatic degradation of coenzyme A. Fed. Proc. 9:209.

29. Novelli, G. D., F. J. Schmetz, and N. O. Kaplan. 1954. Enzymatic degradation and resynthesis of coenzyme A. J. Biol. Chem. 206:533-545.

30. Kornberg, A., and W. E. Pricer. 1950. Nucleotide pyrophosphatase. J. Biol. Chem. 182:763-778.

31. Wang, T. P., L. Shuster, and N. O. Kaplan. 1952. Nature of monoester phosphate group in coenzyme A. J. Am. Chem. Soc. $74: 3204-3205$.

32. Wang, T. P., L. Shuster, and N. O. Kaplan. 1954. The monoester phosphate grouping of coenzyme A. J. Biol. Chem. 206:299-309.

33. Buchanan, J. G., C. A. Dekker, and A. G. Long. 1950. The detection of glycosides and non-reducing carbohydrate derivatives in paper partition chromatography. J. Chem. Soc. (London), pp. 3162-3167. 
34. Brown, D. M., G. D. Fasman, D. I. Magrath, A. R. Todd, W. Cochran, and M. M. Woolfson. 1953. Structure of adeny-

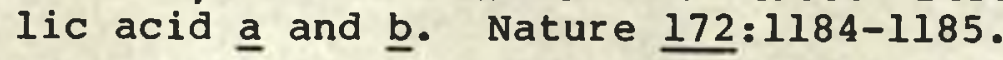

35. Pierpont, W. S., and D. E. Hughes. 1954. The synthesis of coenzyme $A$ by Lactobacillus arabinosus 17-5. Biochem. J. $\underline{56}: 130-135$.

36. Baddiley, J., D. E. Hughes, A. P. Mathias, and w. S. Pierpont. 1954. The phosphorylation of pantothenic acid by Lactobacillus arabinosus 17-5. Biochem. J. 56: xxii-xxiii.

37. Pierpont, W. S., D. E. Hughes, J. Baddiley, and A. P. Mathias. 1955. The phosphorylation of pantothenic acid by Lactobacillus arabinosus 17-5. Biochem. J. $\underline{61: 368-}$ 374 .

38. Ward, G. B., G. M. Brown, and E. E. Snell. 1955. Phosphorylation of pantothenic acid and pantetheine by an enzyme from proteus morganii. J. Biol. Chem. 213:869876 .

39. Brown, G. M., and E. E. Snell. 1954. Pantothenic acid conjugates and growth of Acetobacter suboxydans. J. Bacteriol. 67:465-471.

40. Shimizu, S., K. Kubo, Y. Tani, and R. Ogata. 1973. Purification and properties of pantothenate kinase from Brevibacterium ammoniagenes IFO 12071. Agric. Biol. Chem. 37:2863-2870.

41. Brown, G. M., and E. E. Snell. 1953. N-pantothenylcysteine as a precursor for pantetheine and coenzyme A. J. Am. Chem. Soc. $\underline{75}: 2782-2783$.

42. Brown, G. M., M. Ikawa, and E. E. Snell. 1955. Synthesis and microbiological activity of some pantothenic acid conjugates. J. Biol. Chem. 213:855-867.

43. Brown, G. M., and E. E. Snell. 1954. Pantothenic acid conjugates and growth of Acetobacter suboxydans. J. Bacteriol. 67:465-471.

44. Ogata, K., S. Shimizu, and Y. Tani. 1971. Studies on the metabolism of pantothenic acid in microorganisms. Part I. Distribution of COA-accumulating activity in microorganisms and isolation of reaction products. Agric. Biol. Chem. 36:84-92. 
45. Shimizu, S., K. Kubo, H. Morioka, Y. Tani, and K. Ogata. 1974. Some aspects of the enzyme activities involved in coenzyme A biosynthesis in various microorganisms. Agric. Biol. Chem. 38:1015-1021.

46. King, T. E., and V. H. Cheldelin. 1953. Pantothenic acid derivatives and growth of Acetobacter suboxydans. Proc. Soc. Exp. Biol. Med. 84:591-593.

47. Baddiley, J., and A. P. Mathias. 1954. Coenzyme A. Part IX. The synthesis of pantothenylcysteine, its 4'phosphate, and related compounds as possible precursors of the coenzyme. J. Chem. Soc. (London), pp. 2803-2812.

48. Brown, G. M. 1957. Pantothenylcysteine, a precursor of pantetheine in Lactobacillus helveticus. J. Biol. Chem. $\underline{226}$ : $651-661$.

49. Levintow, L., and G. D. Novelli. 1954. The synthesis of coenzyme A from pantetheine: Preparation and properties of pantetheine kinase. J. Biol. Chem. 207:761-765.

50. Hoagland, M. B., and G. D. Novelli. 1954. Biosynthes is of coenzyme $A$ from phosphopantetheine and of pantetheine from pantothenate. J. Biol. Chem. 207:767-773.

51. Cavallini, D., B. Mondovi, C. DeMarco, and G. FerroLuzzi. 1959. The biosynthesis of COA in the pigeon liver extract. Enzymologia 20:359-365.

52. Abiko, Y. 1967. Investigations on pantothenic acid and its related compounds. IX. Biochemical studies. Separation and substrate specificity of pantothenate kinase and phosphopantothenoylcysteine synthetase. J. Biochem. (Tokyo) 6l:290-299.

53. Wang, T. P. and N. O. Kaplan. 1954. Kinase for the synthesis of coenzyme $A$ and triphosphopyridine nucleotide. J. Biol. Chem. 206:311-325.

54. Abiko. Y., S. I. Ashida, and M. Shimizu. 1972. Purification and properties of D-pantothenate kinase from rat liver. Biochim. Biophys. Acta 268:364-372.

55. Abiko, Y., M. Tomikana, Y. Hosokawa, and M. Shmizu. 1969. Investigations on pantothenic acid and its related compounds. XVII. Biochemical studies. Further studies on the metabolism of pantothenoyl alcohol in rat liver. Chem. Pharm. Bull. 17:200-201. 
56. Abiko, Y., M. Tomikawa, and M. Shimizu. 1968. Further studies on pantothenylcysteine synthetase. J. Biochem. (Tokyo) 64:115-117.

57. Abiko, Y. 1967. Investigations on pantothenic acid and its related compounds. X. Biochemical studies. Purification and substrate specificity of phosphopantothenoylcysteine decarboxylase from rat liver. J. Biochem. (Tokyo) 61:300-308.

58. Abiko, Y., T. Suzuki, and M. Shimizu. 1967. Investigations of pantothenic acid and its related compounds. $X I$. Biochemical studies. A final stage in the biosynthesis of COA. J. Biochem. (Tokyo) 61:309-312.

59. Suzuki T., Y. Abiko, and M. Shimizu. 1967. Investigations of pantothenic acid and its related compounds. XII. Biochemical studies. Dephopho-CoA phosphorylase and dephospho-COA kinase as a possible bifunctional enzyme complex. J. Biochem. (Tokyo) 62:642-649.

60. Ogata, K., Y. Tani, S. Shimuzu, and K. Uno. 1972. Studies on the metabolism of pantothenic acid in microorganisms. Part II. Formation of coenzyme A by Bakers' yeast. Agric. Biol. Chem. 36:93-100.

61. Bucovaz, E. T., C. M. Sobhy, W. C. Morrison, W. D. Whybrew, J. C. Morrison, W. L. Wiser, S. A. Fish, and J. E. Fryer. 1975. Conjugation of cyclic hydrocarbons with coenzyme A-synthesizing protein complex of Bakers' yeast. Proc. Am. Assoc. Cancer Research 16:80.

62. Morrison, J. C., W. C. Morrison, W. D. Whybrew, W. L. Wiser, and E. T. Bucovaz. 1975. Alteration in coenzyme A-synthesizing protein complex activity to cyclic hydrocarbon conjugation. IRCS Medical Science $3: 23$.

63. Bucovaz, E. T., J. C. Morrison, J. L. Rhoades, W. C. Morrison, J. E. Fryer, and W. D. Whybrew. 1976. Purification of the coenzyme A-synthesizing protein complex of Bakers' yeast. Fed. Proc. 35:1672.

64. Bucovaz, E. T., J. C. Morrison, W. C. Morrison, and w. D. Whybrew. 1977. Assay for the detection of a protein component in the serum of individuals with cancer. J. Tenn. Acad. Sci. 52:27-30.

65. Tarnowski, S. J., J. C. Morrison, W. D. Whybrew, and E. T. Bucovaz. 1978. Solubilization characteristics of 
the coenzyme A-synthesizing protein complex of Bakers' yeast. IRCS Medical Science $6: 283$.

66. Tarnowski. S. J., J. C. Morrison, W. D. Whybrew, and E. T. Bucovaz. 1978. Cellular properties of the coenzyme A-synthesizing protein complex of Bakers' yeast. Life Sciences $\underline{23}: 2757-2768$.

67. Wakim, J. M., R. M. Macleod, S. J. Tarnowski, W. D. Whybrew, and E. T. Bucovaz. 1979. Chromatographic and electrophoretic characteristics of the coenzyme Asynthesizing protein complex of Bakers' yeast. IRCS Medical Science $\underline{7}: 70$.

68. Bucovaz, E. T., J. C. Morrison, W. C. Morrison, and W. D. Whybrew. Application of protein-protein interaction as an assay for the detection of cancer. United States Patent No. 4,160,817, Awarded July, 1979.

69. Bucovaz, E. T., J. C. Morrison, W. C. Morrison, and W. D. Whybrew. 1976. Protein-protein interaction used as assay for the detection of abnormal serum protein of patients with cancer. In H. E. Nieburgs (ed.), Prevention and Detection of cancer, Part II. Detection, high rise markers, detection methods and management, Vol. 1 , pp. 257-269, Marcel Dekker, Inc., New York.

70. Nakamura, T., T. Kusunoki, S. Soyana, and M. Kuwagata. 1969. Distribution of pantothenic acid, coenzyme A, and their intermediates in rat liver. III. Isolation of pantothenic acid, 4'-phosphopantetheine, and coenzyme A by column chromatography. Vitamins $\underline{40}: 412-415$.

71. Shimizu, M., and Y. Abiko. 1965. Investigations on pantothenic acid and its related compounds. II. Biochemical studies. Biosynthesis of coenzyme A from pantothenate, pantethine and from S-benzoyl pantetheine in vitro and in vivo. Chem. Pharm. Bull. 13:189-197.

72. Bremer, J., A. Wojtczak, and S. Skrede. 1972. The leakage and destruction of $C O A$ in isolated mitochrondria. Eur. J. Biochem. 25:190-197.

73. Skrede, S. 1973. The degradation of COA: subcellular localization and kinetic properties of $\mathrm{COA}-$ and dephospho-COA pyrophosphatase. Eur. J. Biochem. 38:401-407.

74. Decker, K. and E. Bischoff. 1972. Purification and properties of nucleotide pyrophosphatase from rat liver plasma membranes. FEBS Lett. 21:95-98. 
75. Dupre, S., M. T. Graziani, M. A. Rosei, A. Fabi, and E. Del Grosso. 1970. The enzymatic breakdown of pantethine to pantothenic acid and cysteamine. Eur. J. Biochem. 16:571-578.

76. Abiko, Y. 1975. Metabolism of coenzyme A. In D. M. Greenberg (ed.), Metabolc Pathways, Metabolism of Sulfur Compounds, 3rd Ed., Vol. VII, pp. 1-25, Academic Press, Inc., New York.

77. Powell, G. L., J. Elovson, and P. R. Vagelos. 1969. Acyl carrier protein. XI. The specificity of acyl carrier protein synthetase. J. Biol. Chem. 244:45174521 .

78. Cavallini, D., C. DeMarco, R. Scandura, S. Dupre, and M. T. Graziani. 1966. The enzymatic oxidation of cysteamine to hypotaurine. Purification and properties of the enzyme. J. Biol. Chem. 24l:3189-3196.

79. Dupre, S., M. T. Graziani, and M. A. Rosei. 1970. A new method for the determination of enzymatic pantethinesplitting activity. Ital. J. Biochem. 19:132-138.

80. Lynen, F. 1953. Functional group of coenzyme $A$ and its metabolic relations, especially in the fatty acid cycle. Fed. Proc. 12:683-691.

81. Lynen, F., E. Reichert, and L. Rueff. 1951. Biological degradation of acetic acid. VI. Isolation and chemical nature of activated acetic acid. Ann. Chem. 574:1-32.

82. Hoskinson, R. M., and G. H. Khorana. 1965. Studies on polynucleotides SLI. Purification of phenylalaminespecific transfer ribonucleic acid from yeast by counter current distribution. J. Biol. Chem. 240:2129-2135.

83. Lowry, O. H., N. J. Rosenbrough, A. L. Farr, and R. J. Randall. 1951. Protein measurements with Folin reagent. J. Biol. Chem. 193:265-275.

84. Cohn, E. J., W. L. Hughes, and J. H. Weare. 1947. Preparation and properties of serum and plasma proteins. XIII. Crystallization of serum albumins from ethanolwater mixtures. J. Am. Chem. Soc. 69:1753-1761.

85. Craig, L. C. 1967. Techniques for the study of peptides and proteins by dialysis and diffusion. Meth. Enzymol. 11:870-905. 
86. Schumacher, G. F. B., and W. B. Schill. 1972. Radial diffusion in gel for micro determination of enzymes. II. Plasminogen activator, elastase, and nonspecific protease. Anal. Biochem. $\underline{48: 9-26 .}$

87. DeRenzo, E. C., E. Raleita, P. G. Heytler, J. J. Oleson, B. L. Hutchings, and J. H. Williams. 1953. Identification of the xanthine oxidase factor as molybdenum. Arch. Biochem. Biophys. 45:247-253.

88. Smith, I. 1963. Aminoacids, amines and related compounds. In I. Smith (ed.), Chromatographic and Electrophoretic Techniques, 3rd. Ed., Vol. I, p. 84, Interscience, New York, New York.

89. Hanes, S. S., and F. A. Isherwood. 1949. Separation of the phosphoric esters on the filter paper chromatogram. Nature 164:1107-1112.

90. Toennies, G., and J. J. Kolb. 1951. Techniques and reagent for paper chromatography. Anal. Chem. 23:823826 .

91. Bremner, J. M., and R. H. Kenten. 1951. Paper chromatography by amines. Biochem. J. 49:651-654.

92. Marzullo, G., H. Rosengarten, and A. J. Friedhoff. 1977. A peptide-like inhibitor of N-methyltransferase in rabbit brain. Life Sciences 20:775-784.

93. Bergkvist, R. 1956. The acid-soluble nucleotide of wheat plants. Acta Chem. Scand. 10:1303-1316.

94. Persson, K. O. U. 1963. A comparative investigation of the acid-soluble nucleotides of Penicillium dalae and Penicillium urticae. Acta Chem. Scand. 17:2750-2763.

95. Mandelstam, J. 1958. The free amino acids in growing and non-growing populations of Escherichia coli. Biochem. J. 69:103-110.

96. Schales, O. and S. S. Schales. 1941. A simple and accurate method for the determination of chloride in biological fluids. J. Biol. Chem. 140:879-883.

97. Arnold, W. N. 1972. The structure of the yeast cell wall. Solubilization of a marker enzyme, B-fructofuranosidase by the autolytic enzyme system. J. Biol. Chem. 247:1161-1169. 
98. Ishida-Ichimasa, M. 1978. Degradation of lipids in yeast (Saccharomyces cerevisiae) at the early phase of organic solvent-induced autolysis. Agric. Biol. Chem. 42: $247-251$.

99. Kelmen, M.V., and J. E. E. Sharpe. 1979. Controlled cell disruption: a comparison of the force required to disrupt different microorganisms. J. Cell Sci. $\underline{35: 431-}$ 441 .

100. Vosti, D. C., and M. A. Joslyn. 1954. Autolysis of Bakers' yeast. Appl. Microb. $2: 70-78$.

101. Harrison, J. S., and w. E. Trevelyan. 1963. Phospholipid breakdown in Bakers' yeast during drying. Nature 200:1189-1190.

102. Lenney, J.F. 1956. A study of two yeast proteinases. J. Biol. Chem. 221:919-930.

103. Hagihara, B., T. Horio, J. Yamashita, M. Nozaki, and K. Okunuki. 1956. Preparation of crystalline cytochrome C from yeast. Nature 178:629-630.

104. Arnold, W. N. 1972. Location of acid phosphatase and $\beta$-fructofuranosidase within yeast cell envelopes. J. Bact. 112:1346-1352.

105. Arai, M., and S. Murao. 1978. Red yeast cell lysis by red yeast cell wall lytic enzyme and protease. Agric. Biol. Chem. $\underline{42}: 1461-1467$. 
VITA

Stanley Joseph Tarnowski, Jr., was born on September 17, 1953 in St. Louis, Missouri to Dolores M. and Stanley J. Tarnowski, Sr. He married Deborah Kay Young on August 14. 1974. He was graduated with honors from Southeast Missouri State University in 1975, receiving a Bachelor of Science degree in Chemistry. In July 1975, he entered The University of Tennessee Graduate School-Medical Sciences in the Department of Biochemistry where he was awarded a teaching fellowship. He has accepted a Post-doctoral Fellowship at the Roche Institute of Molecular Biology. He is a member of the American Chemical Society, Sigma Xi and American Association for the Advancement of Science. 